\title{
An Approach for Measuring Reductions in Operations, Maintenance, and Energy Costs for Educational Facilities
}

Robert E. Chapman

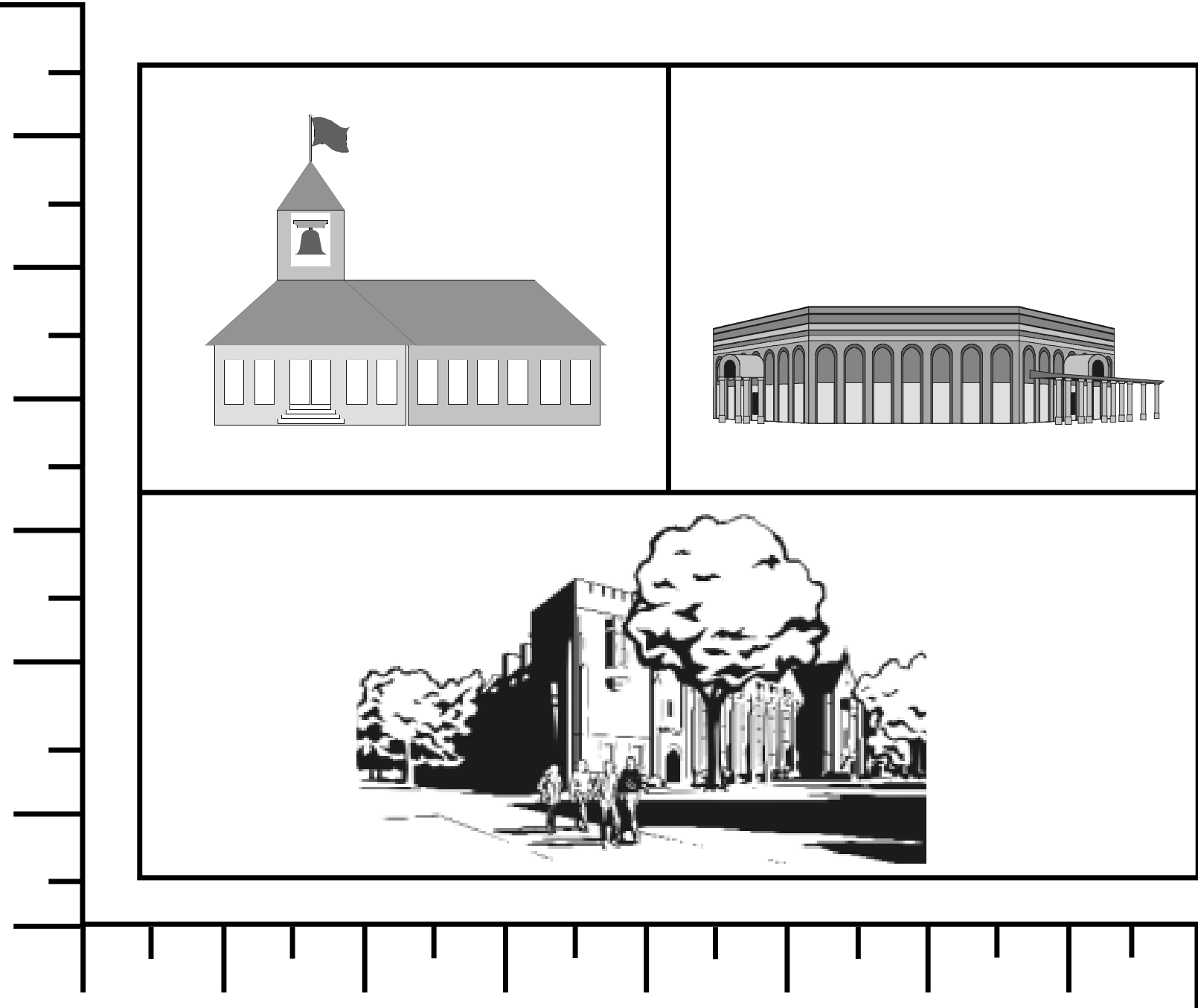





\title{
An Approach for Measuring Reductions in Operations, Maintenance, and Energy Costs for Educational Facilities
}

\author{
Robert E. Chapman
}

Sponsored by:

National Institute of Standards and Technology

Building and Fire Research Laboratory

and

Subcommittee on Construction and Building

Committee on Technology

National Science and Technology Council

Office of Science and Technology Policy

1600 Pennsylvania Avenue, NW

Washington, DC 20502

January 2002
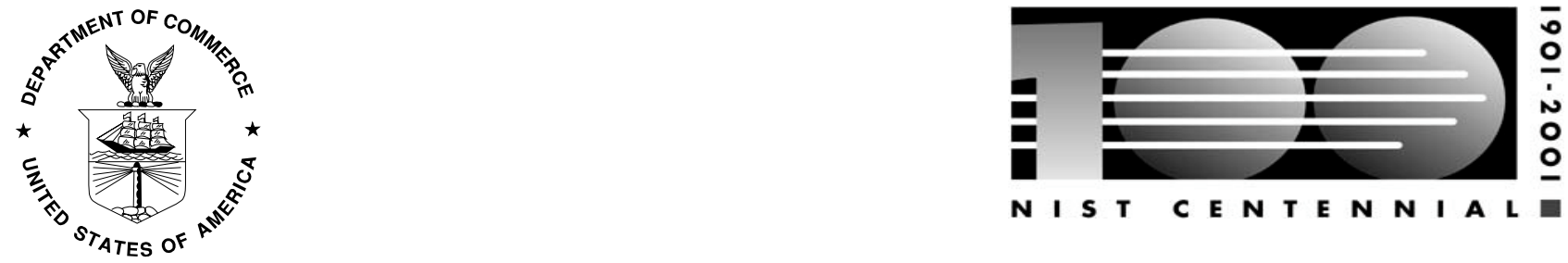

\section{U.S. DEPARTMENT OF COMMERCE}

Donald L. Evans, Secretary

\section{TECHNOLOGY ADMINISTRATION}

Philip J. Bond, Under Secretary for Technology

NATIONAL INSTITUTE OF STANDARDS AND TECHNOLOGY

Arden L. Bement, Jr., Director 


\begin{abstract}
The Construction and Building Subcommittee of the National Science and Technology Council is developing baseline measures of current construction industry practices and measures of progress with respect to each of the seven National Construction Goals. The seven National Construction Goals are concerned with: (1) reductions in the delivery time of constructed facilities; (2) reductions in operations, maintenance, and energy costs; (3) increases in occupant productivity and comfort; (4) reductions in occupant-related illnesses and injuries; (5) reductions in waste and pollution; (6) increases in the durability and flexibility of constructed facilities; and (7) reductions in construction worker illnesses and injuries. This report provides a detailed set of baseline measures for National Construction Goal 2 (reductions in operations, maintenance, and energy costs) for educational facilities. As such, it describes data sources, data classifications, and the metrics used to develop the baseline measures. Extensive use of charts and tables is made throughout this document to illustrate the process by which the baseline measures were developed.
\end{abstract}

\title{
Keywords
}

building economics; construction; costs; economic analysis; educational facilities; energy costs; maintenance costs; metrics; operations costs 


\section{Preface}

This study was conducted by the Office of Applied Economics in the Building and Fire Research Laboratory (BFRL) at the National Institute of Standards and Technology (NIST). The study was sponsored by the Construction and Building Subcommittee of the National Science and Technology Council. The BFRL project, of which this study is a part, seeks to develop baseline measures and measures of progress with respect to each of the seven National Construction Goals. These measures are to be disseminated both through publications and, ultimately, electronically via the World Wide Web. The intended audience for this report is the Construction and Building Subcommittee member organizations as well as construction industry representatives and other interested parties. 


\section{Acknowledgments}

The author wishes to thank all those who contributed so many excellent ideas and suggestions that he has attempted to incorporate into this report. The author wishes to thank Dr. Jack E. Snell and Mr. John Talbott, Co-Chairs of the Construction and Building Subcommittee, and Dr. Andrew J. Fowell, Secretariat of the Construction and Building Subcommittee, for their guidance, suggestions, and support. Special appreciation is extended to Drs. Harold E. Marshall and Sieglinde K. Fuller of the Office of Applied Economics at NIST's Building and Fire Research Laboratory (BFRL) for the thoroughness of their reviews and for their many insights and to Ms. Catherine Linthicum and Mrs. J'aime Maynard for their assistance in preparing the manuscript for review and publication. Special appreciation is also extended to Messrs. Karthy Kasi and Daniel Cardy, formerly with BFRL's Office of Applied Economics, who helped immensely with the data collection and analysis effort during their summer internships. Thanks are also due to Ms. Christine Izzo of BFRL's Office of Applied Economics for her comments on the earlier drafts of this report and for her assistance in interpreting the results of the data analysis effort. 


\section{Table of Contents}

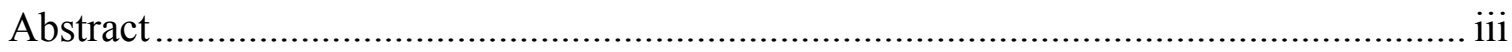

Preface

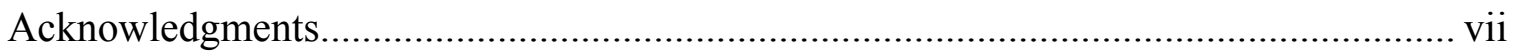

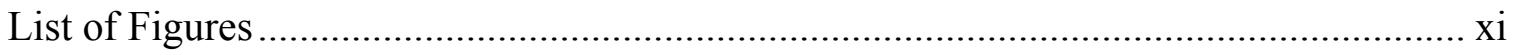

List of Tables ......................................................................................................... xii

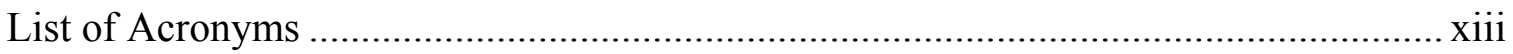

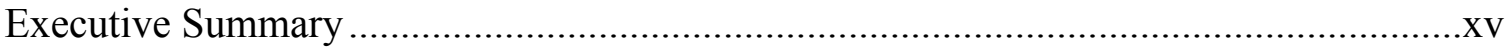

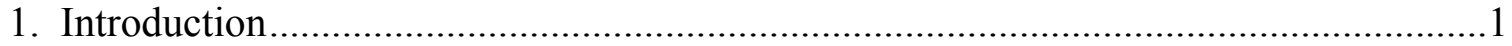

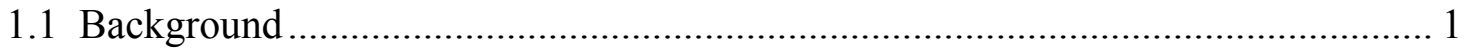

1.2 Purpose

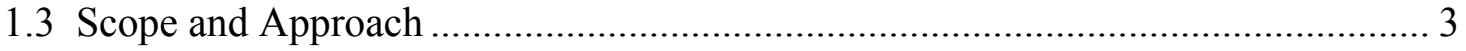

2. The National Construction Goals: A Tool for Promoting Competitiveness Within the

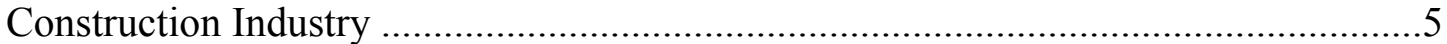

2.1 Description of the National Construction Goals ................................................... 5

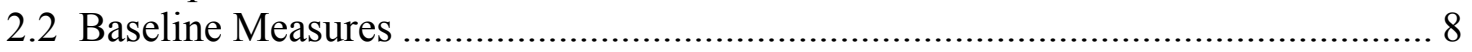

2.3 How This Document Helps................................................................................ 8

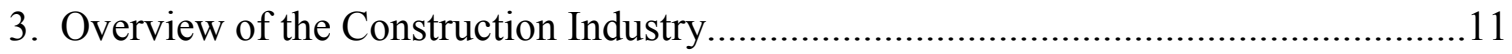

3.1 Value of Construction Put in Place................................................................. 12

3.2 Overview of the Commercial/Institutional Sector ................................................. 17

3.3 Characteristics of Educational Facilities............................................................. 21

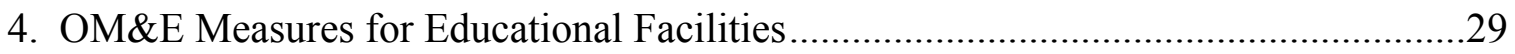

4.1 Data Considerations: Sources, Availability, and Constraints ................................. 29

4.2 Baseline Measures for Educational Facilities ....................................................... 32

4.2.1 Baseline Measures for K-12 Facilities .......................................................... 32

4.2.2 Baseline Measures for College and University Facilities ................................. 34

4.2.3 Energy Conservation in Educational Facilities................................................ 42

4.3 Summary of Baseline Measures for Educational Facilities .................................... 51

5. Summary and Suggestions for Further Research....................................................53

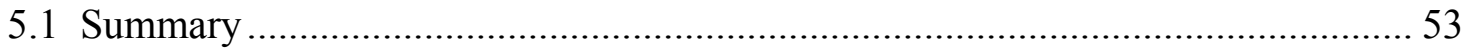


5.2 Suggestions for Further Research.

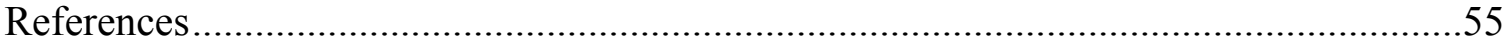




\section{List of Figures}

Figure 3-1. 1997 Breakdown of $\$ 657$ Billion Construction Market.................................18

Figure 3-2. 1997 Breakdown of \$206 Billion Commercial/Institutional Sector ..............20

Figure 3-3. Total Number of Educational Facilities by Size Category: 1995 .................23

Figure 3-4. Total Educational Floorspace by Building Size Category: 1995 ..................23

Figure 3-5. Total Educational Floorspace by Building Size Category and

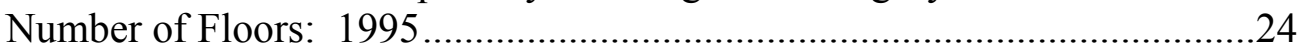

Figure 3-6. Total Number of Educational Facilities by Year of Construction: 1995.

Figure 3-7. Total Educational Floorspace by Year of Construction: 1995 .....................26

Figure 3-8. Total Educational Floorspace by Year of Construction and Number of Floors: 1995.

Figure 4-1. Distribution of Major Repair Costs by Building Element Over a 50-Year Period

Figure 4-2. Selected Annual Operations Costs for College and University Facilities

Figure 4-3. Annual Building and Custodial Maintenance Costs for Colleges and Universities by Number of Students

Figure 4-4. Annual Electricity Cost by Funding Source for Colleges and Universities

Figure 4-5. Annual Mean Gas Cost by Funding Source for Colleges and Universities

Figure 4-6. Sum of Annual Major Fuel Expenditures of Educational Facilities by Building Size Category

Figure 4-7. Sum of Annual Major Fuel Expenditures of Educational Facilities by Year of Construction

Figure 4-8. Heating Equipment Usage in Educational Buildings by Building Size Category. 
Figure 4-9 Building Cooling Equipment Usage in Educational Buildings by Building Size Category

Figure 4-10. Building Lighting Equipment Usage in Educational Buildings by Building Size Category

Figure 4-11. Educational Facilities Shell Conservation Features by Building Size Category

Figure 4-12. Educational Facilities HVAC Conservation Features by Building Size Category.....

Figure 4-13. Educational Facilities Lighting Conservation Features by Building Size Category 50

\section{List of Tables}

Table 3-1. Value of Construction Put in Place in Millions of Constant 1997 Dollars

Table 3-2. Value of Construction Put in Place in Millions of Current Dollars 15

Table 3-3. Value of Construction Put in Place: Sector Totals and Sum Total in Millions of Constant 1997 Dollars.

Table 3-4. Value of Construction Put in Place: Sector Totals and Sum Total in Millions of Current Dollars

Table 4-1. Annual Operations, Maintenance, and Energy Costs for K-12 Facilities

Table 4-2. Most Costly Major Repair Tasks Over a 50 Year Period .35

Table 4-3. Annual Operations, Maintenance, and Energy Costs for College and University Facilities

Table 4-4. Selected Annual Operations Costs for College and University Facilities by Funding Source, Region, and Number of Students

Table 4-5. Annual Mean Electricity Usage for College and University Facilities by Funding Source, Region, and Number of Students. .40 
Table 4-6. Annual Mean Gas Consumption for College and University Facilities by Funding Source, Region, and Number of Students

Table 4-7. Summary of OM\&E Baseline Measures for Educational Facilities.

\section{List of Acronyms}

\begin{tabular}{|c|l|}
\hline Acronym & \multicolumn{1}{c|}{ Definition } \\
\hline APPA & The Association of Higher Education Facilities Officers \\
\hline AS\&U & American School and University \\
\hline ASTM & American Society for Testing and Materials \\
\hline BFRL & Building and Fire Research Laboratory \\
\hline C\&B & Construction and Building \\
\hline CBECS & Commercial Building Energy Consumption Survey \\
\hline CEFPI & Council of Educational Facility Planners, International \\
\hline DOE & Department of Energy \\
\hline EIA & Energy Information Administration \\
\hline ERIC & Educational Resource Information Center \\
\hline FTE & Full-Time Equivalent \\
\hline HVAC & Heating, Ventilation, and Air Conditioning \\
\hline NCEF & National Clearinghouse for Educational Facilities \\
\hline NCG & National Construction Goal \\
\hline NIBS & National Institute of Building Sciences \\
\hline OM\&E & Operations, Maintenance, and Energy \\
\hline RD\&D & Research, Development, and Deployment \\
\hline
\end{tabular}


xiv 


\section{Executive Summary}

The National Science and Technology Council, a cabinet-level group chaired by the President, is charged with setting federal technology policy and coordinating R\&D strategies across a broad cross-section of public and private interests. It has established nine research and development committees, including the Committee on Technology (CT), to collaborate with the private sector in developing a comprehensive national technology policy. The purpose of CT is to enhance the international competitiveness of US industry through federal technology policies and programs. The Construction and Building Subcommittee of CT coordinates and defines priorities for federal research, development, and deployment related to the industries that produce, operate, and maintain constructed facilities, including buildings and infrastructure.

The mission of the Construction and Building Subcommittee is to enhance the competitiveness of the US industry, public safety, and environmental quality through research and development, in cooperation with US industry, labor, and academia, for improvement of the life cycle performance of constructed facilities. To accomplish its mission, the Construction and Building Subcommittee has established seven National Construction Goals in collaboration with a broad cross section of the construction industry.

Data describing current practices of the US construction industry are needed to establish baselines against which the industry can measure its progress towards achieving the seven National Construction Goals. The Goals are: (1) reductions in the delivery time of constructed facilities; (2) reductions in operations, maintenance, and energy costs; (3) increases in occupant productivity and comfort; (4) reductions in occupant-related illnesses and injuries; (5) reductions in waste and pollution; (6) increases in the durability and flexibility of constructed facilities; and (7) reductions in construction worker illnesses and injuries. Baseline measures and measures of progress will be produced for each National Construction Goal in each of the four key construction industry sectors. The four sectors are: (1) residential; (2) commercial/institutional; (3) industrial; and (4) public works.

This document provides a detailed set of baseline measures for National Construction Goal 2 (reductions in operations, maintenance, and energy costs) for educational facilities. Industry performance in 1994 is used as the reference point from which the values of the baseline measures are calculated. Goal 2 was identified as one of the highest priority National Construction Goals by the construction industry.

This document has five chapters. Chapter 1 explains the purpose, scope, and general approach. Chapter 2 introduces the National Construction Goals, describes how a welldefined set of metrics is used to develop the baseline measures, and outlines the project approach. Chapter 3 provides an overview of the construction industry. The overview provides the context within which the baseline measures are developed. Chapter 4 
presents the baseline measures. Chapter 5 concludes the document with a summary and suggestions for further research.

Chapter 2 provides perspective on the overall effort to develop baseline measures for each of the seven National Construction Goals. First, each National Construction Goal is introduced and described. Next, the process for developing baseline measures for each Goal is described. This process involves: (1) specifying data relationships; (2) collecting and compiling the key data and supporting information for the base year, 1994; (3) defining metrics for each goal/sector combination; and (4) producing the metrics in a summary form (i.e., figures and tables to depict the metrics). Criteria are then presented which ensure that the data selected for analysis are well defined, consistent, and replicable. The chapter also outlines a strategy for using the baseline measures to drive performance improvement.

Chapter 3 provides a snapshot of the US construction industry. It provides the context within which the baseline measures are developed. An extensive set of statistics has been compiled on each sector; many of these statistics are included in Chapter 3. These statistics are useful not only as a tool for defining the baseline measures but also as a resource reference for readers with a wide variety of interests in the construction industry.

Information is first presented on the value of construction put in place to show the size of the construction industry and each of its four sectors. The four sectors are residential, commercial/institutional, industrial, and public works. Information on the commercial/ institutional sector is then presented to focus on its importance within the overall construction industry and to define its key components. Educational facilities are shown to be a key component of the commercial/institutional sector. Special emphasis is then placed on detailing the key characteristics of educational facilities (e.g., building floorspace and year of construction). Detailing the key characteristics of educational facilities is crucial because investments in these facilities affect not only new construction activities, but additions and alterations and maintenance and repair activities as well.

The construction industry is a key component of the US economy. A key indicator of construction activity is the value of construction put in place. Data published by the US Bureau of the Census are used to establish the composition of construction expenditures by type of construction. These expenditures are then assigned to one of the four key construction industry sectors.

Table ES-1 summarizes both the annual sector totals and the sum total. Since 1994, the value of construction put in place has risen from $\$ 571.3$ billion in 1994 to $\$ 734.3$ billion in 2000 in constant 1997 dollars. The largest component of construction over this period was in the residential sector (about 45 percent of the total), with the smallest component in the industrial sector (about 6 percent). 
Table ES-1. Value of Construction Put in Place in Millions of 1997 Dollars: Sector Totals and Sum Total

\begin{tabular}{|l|c|c|c|c|c|c|c|}
\hline \multirow{2}{*}{ Sector } & \multicolumn{7}{|c|}{ Value of Construction Put in Place (\$ Millions) } \\
\cline { 2 - 8 } & 1994 & 1995 & 1996 & 1997 & 1998 & 1999 & 2000 \\
\hline Residential & 266,876 & 266,089 & 295,555 & 294,244 & 311,248 & 331,705 & 341,738 \\
\hline $\begin{array}{l}\text { Commercial/ } \\
\text { Institutional }\end{array}$ & 152,521 & 165,828 & 184,237 & 205,703 & 215,774 & 221,308 & 233,329 \\
\hline Industrial & 33,440 & 37,511 & 38,844 & 37,738 & 40,393 & 33,521 & 29,925 \\
\hline Public Works & 118,434 & 117,111 & 115,034 & 118,944 & 125,459 & 128,671 & 129,280 \\
\hline $\begin{array}{l}\text { Total - All } \\
\text { Sectors }\end{array}$ & 571,271 & 586,539 & 633,670 & 656,629 & 692,874 & 715,205 & 734,272 \\
\hline
\end{tabular}

Source: US Bureau of the Census.

Chapter 4 presents the baseline measures. These measures are based on data published by four sources: (1) the Energy Information Administration (EIA), a part of the US Department of Energy (DOE); (2) the Association of Higher Education Facilities Officers (APPA); (3) the American School \& University (AS\&U) Magazine; and (4) Whitestone Research. Section 4.1 describes each of the data sets. The baseline measures are reported and described in Section 4.2. Section 4.2.1 covers K-12 facilities. Section 4.2.2 covers college and university facilities. Section 4.2.3 uses data from the EIA's Commercial Buildings Energy Consumption Survey (CBECS) to establish the national average energy cost per unit of floor area and the rates of utilization of energy conserving features and practices. The chapter concludes with a summary of the various baseline measures for operations, maintenance, and energy (OM\&E) costs for educational facilities.

Because the OM\&E baseline measures presented in Chapter 4 are drawn from several key documents, a comprehensive list of OM\&E cost components are identified and defined. These components include the following:

- administration - includes all administrative costs for the facility including payroll costs, equipment, supplies, communications, computer rental, accounting costs, and training costs

- work control - includes all costs necessary for the proper planning, scheduling, and dispatching of maintenance work, including payroll, database maintenance, supervision, and cost estimation

- engineering/architecture - includes all design and engineering costs

- project management - includes all costs associated with actual estimating, contracting, inspecting, and final approval of new or renovated construction

- building maintenance - includes in-house and contracted services for routine repairs, minor corrective maintenance, preventive maintenance and service calls for HVAC, plumbing, electrical, painting, glazing, and elevators 
- custodial maintenance - includes interior and exterior functions such as window and building cleaning, snow removal, and operating costs such as towels

- grounds maintenance - includes landscaping and grounds maintenance costs for parking areas, irrigation systems, and fencing

- utilities operations - includes all costs for heating, cooling, lighting, and other utilities for physical plant operations, excluding cost of fuel and purchased utilities

- solid waste disposal - includes all costs associated with refuse removal

- hazardous waste disposal - includes all costs associated with hazardous waste removal

- $\quad$ security - includes all security expenses such as traffic, parking, and building security

Table ES-2 summarizes the baseline measures for educational facilities that are presented in Sections 4.2.1, 4.2.2, and 4.2.3 of this document. The table is organized to serve as a quick reference; it includes a brief description of each measure, the year for the data, the value of the measure in dollars per square meter $\left(\$ / \mathrm{m}^{2}\right)$ and dollars per square foot $\left(\$ / \mathrm{ft}^{2}\right)$, and the source of the data. Two sets of summary OM\&E measures are presented firstone for K-12 facilities and one for college and university facilities - followed by a more detailed set of measures.

Chapter 5 discusses additional areas of research that might be of value to government agencies and private bodies who are concerned about reducing operations, maintenance, and energy costs in educational facilities. These areas of research are concerned with: (1) the dissemination of more detailed information on building characteristics and energy consumption by EIA that would facilitate the construction of measures for K-12 facilities and for college and university facilities rather than general measures for educational facilities as a whole; and (2) the measurement and evaluation of progress toward achievement of National Construction Goals 2 in educational facilities. 
Table ES-2. Summary of OM\&E Baseline Measures for Educational Facilities

\begin{tabular}{|c|c|c|c|}
\hline DESCRIPTION & YEAR & BASELINE & SOURCE \\
\hline OM\&E: K-12 Facilities & 1996 & $\$ 35.74 / \mathrm{m}^{2}\left(\$ 3.32 / \mathrm{ft}^{2}\right)$ & AS\&U \\
\hline $\begin{array}{l}\text { OM\&E: College \& University } \\
\text { Facilities }\end{array}$ & 1996 & $\$ 37.78 / \mathrm{m}^{2}\left(\$ 3.51 / \mathrm{ft}^{2}\right)$ & AS\&U \\
\hline $\begin{array}{l}\text { Average Custodial (Cleaning) } \\
\text { Cost }\end{array}$ & $\begin{array}{r}1993- \\
1994\end{array}$ & $\$ 9.81 / \mathrm{m}^{2}\left(\$ 0.91 / \mathrm{ft}^{2}\right)$ & APPA \\
\hline Average Grounds Cost & $\begin{array}{l}1993- \\
1994\end{array}$ & $\$ 2.96 / \mathrm{m}^{2}\left(\$ 0.28 / \mathrm{ft}^{2}\right)$ & APPA \\
\hline $\begin{array}{l}\text { Average Solid Waste Disposal } \\
\text { Cost }\end{array}$ & $\begin{array}{l}1993- \\
1994\end{array}$ & $\$ 0.56 / \mathrm{m}^{2}\left(\$ 0.05 / \mathrm{ft}^{2}\right)$ & APPA \\
\hline $\begin{array}{l}\text { Average Hazardous Waste } \\
\text { Disposal Cost }\end{array}$ & $\begin{array}{l}1993- \\
1994\end{array}$ & $\$ 0.40 / \mathrm{m}^{2}\left(\$ 0.04 / \mathrm{ft}^{2}\right)$ & APPA \\
\hline Average Security Cost & $\begin{array}{l}1993- \\
1994\end{array}$ & $\$ 3.81 / \mathrm{m}^{2}\left(\$ 0.35 / \mathrm{ft}^{2}\right)$ & APPA \\
\hline $\begin{array}{l}\text { Average Building Maintenance } \\
\text { Cost }\end{array}$ & $\begin{array}{l}1993- \\
1994\end{array}$ & $\$ 9.63 / \mathrm{m}^{2}\left(\$ 0.90 / \mathrm{ft}^{2}\right)$ & APPA \\
\hline Average Electricity Cost & $\begin{array}{l}1993- \\
1994\end{array}$ & $\$ 10.61 / \mathrm{m}^{2}\left(\$ 0.99 / \mathrm{ft}^{2}\right)$ & APPA \\
\hline Average Gas Cost & $\begin{array}{l}1993- \\
1994\end{array}$ & $\$ 3.54 / \mathrm{m}^{2}\left(\$ 0.33 / \mathrm{ft}^{2}\right)$ & APPA \\
\hline Average Water and Sewer Cost & $\begin{array}{l}1993- \\
1994\end{array}$ & $\$ 0.43 / \mathrm{m}^{2}\left(\$ 0.04 / \mathrm{ft}^{2}\right)$ & APPA \\
\hline $\begin{array}{l}\text { Sum of Major Fuel Expenditures: } \\
\text { All Educational Facilities }\end{array}$ & 1995 & $\$ 9.90 / \mathrm{m}^{2}\left(\$ 0.92 / \mathrm{ft}^{2}\right)$ & CBECS \\
\hline
\end{tabular}




\section{Introduction}

\subsection{Background}

The National Science and Technology Council, a cabinet-level group chaired by the President, is charged with setting federal technology policy and coordinating R\&D strategies across a broad cross-section of public and private interests. It has established nine research and development committees, including the Committee Technology (CT), to collaborate with the private sector in developing a comprehensive national technology policy. The purpose of CT is to enhance the international competitiveness of US industry through federal technology policies and programs. The Construction and Building Subcommittee of CT coordinates and defines priorities for federal research, development, and deployment related to the industries that produce, operate, and maintain constructed facilities, including buildings and infrastructure. ${ }^{1}$

The mission of the Construction and Building Subcommittee is to enhance the competitiveness of US industry, public safety, and environmental quality through research and development, in cooperation with US industry, labor, and academia, for improvement of the life cycle performance of constructed facilities. To accomplish its mission, the Construction and Building Subcommittee has established seven National Construction Goals in collaboration with a broad cross section of the construction industry. $^{2}$

Data describing current practices of the US construction industry are needed to establish baselines against which industry can measure its progress towards achieving the seven National Construction Goals. The seven National Construction Goals are concerned with: (1) reductions in the delivery time of constructed facilities; (2) reductions in operations, maintenance, and energy costs; (3) increases in occupant productivity and comfort; (4) reductions in occupant-related illnesses and injuries; (5) reductions in waste and pollution; (6) increases in the durability and flexibility of constructed facilities; and (7) reductions in construction worker illnesses and injuries.

Although information having relevance to the seven goals is available, for the most part, this information has such a narrow focus that a consistent set of baseline measures and associated measures of progress cannot be produced without first conducting a significant research effort. Specifically, information from a wide variety of data sets needs to be collected, reviewed, analyzed, and critiqued to ensure that the baseline measures and measures of progress which result are:

\footnotetext{
${ }^{1}$ Wright, Richard N. 1995. "Government and Industry Working Together." Construction Business Review (January/February): pp. 44-49.

${ }^{2}$ Wright, Richard N., Arthur H. Rosenfeld, and Andrew J. Fowell. 1995. Construction and Building: Federal Research and Development in Support of the US Construction Industry. Washington, DC: National Science and Technology Council.
} 
(1) adequate (i.e., they not only capture the complexities of the US construction industry, but also represent a consensus among experts in the field); and

suitable for dissemination to the public.

It is essential to have baseline data and associated measures of progress to determine the success of actions taken to improve the competitiveness of the US construction industry. In addition, baselines and measures of progress will make it possible to demonstrate the benefits of advanced technologies and practices, and to guide decision makers in prioritizing potential programs.

The goal of this project is to develop a suite of products that support the measurement and attainment of the National Construction Goals by the four key construction industry sectors. The four industry sectors are: (1) residential; (2) commercial/institutional; (3) industrial; and (4) public works. Three basic sets of products are envisioned:

(1) Baseline Measures: Develop baseline measures that characterize current industry performance with respect to each of the seven goals. The averages of current practice (defined in this document as industry performance in 1994) will become the baselines for measuring progress towards achieving each of the goals.

(2) Measures of Progress: Develop methods for measuring progress. These "results" measures are envisioned as a composite of performance measures offering a means not only for monitoring actual performance, but also for marshaling support for improving results.

(3) Periodic Reports: Provide information on each of the seven goals. This information will be made available to interested parties both through publications and, ultimately, electronically via the World Wide Web.

\subsection{Purpose}

The purpose of this document is to provide a detailed set of baseline measures for National Construction Goal 2 (reductions in operations, maintenance, and energy costs) for educational facilities. As such, it describes data sources, data classifications, and the metrics used to develop the baseline measures. Extensive use of charts and tables is made throughout this document to illustrate the process by which the baseline measures were developed. The focus of this document is on educational facilities. Readers wishing a comprehensive set of baseline measures for each sector of the construction industry are referred to a companion document. ${ }^{3}$

\footnotetext{
${ }^{3}$ Chapman, Robert E., and Roderick Rennison. 1998. An Approach for Measuring Reductions in Operations, Maintenance, and Energy Costs: Baseline Measures of Construction Industry Practices for the National Construction Goals. NISTIR 6185, Gaithersburg, MD: National Institute of Standards and Technology.
} 
The intended audience for this document is the Construction and Building Subcommittee member organizations, ${ }^{4}$ four private sector organizations with interest in specific building sectors, ${ }^{5}$ designers and managers of educational facilities, construction industry representatives, and other interested parties. In addition, because this document includes both detailed information on the baseline measures for National Construction Goal 2 and a compilation of statistics on the four sectors and the construction industry as a whole, it is anticipated that this document will serve as a resource reference for readers with a wide variety of interests in the construction industry.

\subsection{Scope and Approach}

This document has four chapters in addition to the Introduction. Chapter 2 introduces the National Construction Goals and describes how a well-defined set of metrics is used to develop the baseline measures. Chapter 3 provides an overview of the construction industry. The overview provides the context within which the baseline measures are developed. Chapter 4 presents the baseline measures for educational facilities. Key baseline measures are summarized in Table 4-7, which appears at the end of Chapter 4. Chapter 5 concludes the document with a summary and suggestions for further research.

\footnotetext{
${ }^{4}$ The following Federal Agencies are members of the Construction and Building Subcommittee: Department of Agriculture, Department of Commerce, Department of Defense, Department of Education, Department of Energy, Department of Health and Human Services, Department of Housing and Urban Development, Department of Interior, Department of Labor, Department of Transportation, Department of Veterans Affairs, Environmental Protection Agency, General Services Administration, National Aeronautics and Space Administration, and National Science Foundation.

${ }^{5}$ The four private sector organizations are: (1) National Association of Home Builders Research Center (residential); (2) National Institute of Building Sciences (commercial/institutional); (3) Construction Industry Institute (industrial); and (4) American Public Works Association (public works).
} 


\section{The National Construction Goals: A Tool for Promoting Competitiveness Within the Construction Industry}

\subsection{Description of the National Construction Goals}

The Construction and Building (C\&B) Subcommittee has studied research priorities expressed by the construction industry. These priorities translate into the following seven National Construction Goals:

1. $50 \%$ Reduction in Delivery Time

2. $50 \%$ Reduction in Operation, Maintenance, and Energy Costs

$3 . \quad 30 \%$ Increase in Productivity and Comfort

4. $\quad 50 \%$ Fewer Occupant-Related Illnesses and Injuries

5. $\quad 50 \%$ Less Waste and Pollution

6. $\quad 50 \%$ More Durability and Flexibility

7. $50 \%$ Reduction in Construction Worker Illnesses and Injuries

To make the National Construction Goals operational, they are based on the values of a well-defined set of baseline measures. The values of the baseline measures for each goal are averages of industry performance in 1994. The year 1994 was established as the basis for computing the values of the baseline measures because it was the year when the National Construction Goals were first formulated. ${ }^{6}$

Two priority thrusts - better constructed facilities, and improved health and safety of the construction work force-were defined as the focus of C\&B-related research, development, and deployment (RD\&D) activities. The objective of the C\&B-related RD\&D activities is to make technologies and practices capable of achieving the goals under the two priority thrusts available for general use in the construction industry by 2003.

Achievement of the National Construction Goals will: (1) reduce the first costs and lifecycle costs of constructed facilities in the four key construction industry sectors (i.e., residential, commercial/institutional, industrial, and public works); (2) result in better constructed facilities; and (3) result in improved health and safety for both construction workers and occupants of constructed facilities. Achievement of the goals will convey benefits to each of the four construction industry sectors (e.g., housing will become more affordable through reductions in first costs and life-cycle costs). However, depending on the goal and the construction industry sector, the beneficial impacts are expected to vary. To gain a better appreciation of the importance of the National Construction Goals, both individually, and taken together, and of their relationship to the four key construction

\footnotetext{
${ }^{6}$ Wright, Richard N., Arthur H. Rosenfeld, and Andrew J. Fowell. 1994. Rationale and Preliminary Plan for Federal Research for Construction and Building. NISTIR 5536. Washington, DC: National Science and Technology Council.
} 
industry sectors, a brief description of each goal follows. The descriptions are patterned after those given in the report by Wright, Rosenfeld, and Fowell. ${ }^{7}$

Goal 1: $\quad 50 \%$ Reduction in Delivery Time

Delivery time is defined as the elapsed time from the decision to construct a new facility until its readiness for service. Delivery time issues affect both industrial competitiveness and project costs. During the initial planning, design, procurement, construction, and start-up process, the needs of the client are not being met. Furthermore, the client's needs evolve over time, so a facility long in delivery may be uncompetitive or unsuitable when it is finished. Delays almost always translate into increased project costs due to inflationary effects, higher financial holding costs, and reduced productivity. Furthermore, the investments in producing the facility cannot be recouped until the facility is operational. Owners, users, designers, and constructors are among the groups calling for technologies and practices to reduce delivery time.

Goal 2: $\quad 50 \%$ Reduction in Operations, Maintenance, and Energy Costs

Operations, maintenance, and energy $(\mathrm{OM} \& \mathrm{E})$ costs are a major factor in the life-cycle costs of a constructed facility. In some cases, OM\&E costs over the life of a facility exceed its first cost. However, because reductions in OM\&E costs are often associated with increased first costs, facility owners and managers may under-invest in cost saving technologies. Furthermore, undue attention on minimizing first costs may result in a facility which is expensive to operate and maintain, wastes energy resources, is inflexible, and rapidly becomes obsolete. Finally, because OM\&E costs tend to increase more rapidly than the general rate of inflation, facility owners and operators are often forced to reallocate funds to cover $\mathrm{OM} \& \mathrm{E}$ costs. Reductions in $\mathrm{OM} \& \mathrm{E}$ costs will produce two types of benefits. First, constructed facilities will become more affordable because facility owners and operators are making more cost-effective choices among investments (e.g., design configurations) which affect life-cycle costs. Second, these same facilities will better conserve scarce energy resources.

Goal 3: $\quad 30 \%$ Increase in Productivity and Comfort

Industry and government studies have shown that the annual salary costs of the occupants of a commercial or institutional building are of the same order of magnitude as the capital cost of the building. ${ }^{8}$ Occupant comfort depends largely on the nature of buildings, building furnishings, and indoor environments. The quality of indoor environments also has a large impact on occupant health and productivity. Improvement of the productivity of the occupants (or for an industrial facility, improvement of the productivity of the

\footnotetext{
${ }^{7}$ Wright, Richard N., Arthur H. Rosenfeld, and Andrew J. Fowell. 1995. Construction and Building: Federal Research and Development in Support of the US Construction Industry. Washington, DC: National Science and Technology Council.

${ }^{8}$ Building Owners and Managers Association. 1994. Experience Exchange Report, National CrossTabulations, 1994. Washington, DC: Building Owners and Managers Association.
} 
process housed by the facility) is an important performance characteristic for most constructed facilities.

Goal 4: $\quad 50 \%$ Fewer Occupant-Related Illnesses and Injuries

Buildings are intended to shelter and support human activities, yet the environment and performance of buildings can contribute to illnesses and injuries for building users. Examples are avoidable injuries caused by fire, natural hazards, slips, and falls; disease from airborne microbes, often associated with a workplace environment; and building damage or collapse from fire, earthquakes, or extreme winds. Reductions in illnesses and injuries will increase building users' productivity as well as reduce the costs of medical care and litigation.

Goal 5: $\quad 50 \%$ Less Waste and Pollution

Improvement of the performance of constructed facilities provides major opportunities to reduce waste and pollution at every step of the delivery process, from raw material extraction to final demolition and recycling of the facility and its contents. Additional reductions come from reduced energy use, reduced water consumption, and reductions in waste water production, which are considered in part by Goal 2.

Goal 6: $\quad 50 \%$ More Durability and Flexibility

Durability denotes the capability of the constructed facility to continue (given appropriate maintenance) its initial performance over the intended service life. Flexibility denotes the capability to adapt the constructed facility to changes in use or users' needs. Increased durability and flexibility of constructed facilities reduces life-cycle costs and prolongs the economic life of the facility (i.e., the period of time over which an investment in the original facility is considered to be the least-cost alternative for meeting a particular objective).

Goal 7: $\quad 50 \%$ Reduction in Construction Worker Illnesses and Injuries

Health and safety issues exert a major effect on the competitiveness of the US construction industry. Construction workers die as a result of work-related trauma at a rate which is higher than all other industries except mining and agriculture. Construction workers also experience a higher incidence of nonfatal injuries resulting in days away from work than workers in other industries do. Although the construction workforce represents less than $6 \%$ of the nation's work force, it is estimated that the construction industry pays about $15 \%$ of the nation's workers' compensation. ${ }^{9}$

\footnotetext{
9 The Center to Protect Workers' Rights. 1997. The Construction Chart Book: The US Construction Industry and Its Workers. Report D1-97. Washington, DC: The Center to Protect Workers' Rights.
} 


\subsection{Baseline Measures}

As noted earlier, the baseline measures for each goal are averages of industry performance in 1994. Thus, with regard to the baseline measures, 1994 is the "base year." Consequently, data from 1994 drive the data collection effort culminating with the development of the baseline measures for each National Construction Goal.

The process for developing baseline measures used in this project involves: (1) specifying data relationships; (2) collecting and compiling the key data and supporting information for the base year, $1994 ;{ }^{10}$ (3) defining metrics for each goal/sector combination; and (4) producing the metrics in a tabular summary form and, where appropriate, producing charts and graphs to depict the metrics. If the goal/sector combination has components and subcomponents, then metrics are defined for each. This process is employed because the metrics represent not only a statement of current construction industry performance, but tools for measuring an individual organization's performance as well. By providing a small set of well-defined metrics, individual organizations can construct their own performance baselines. For example, individual organizations can see how a collection of their projects performs vis-à-vis the "national" data. To summarize, the basic philosophy behind the baseline measures is that they are not a static tool whose sole purpose is quantifying the value of the goal, but a means for driving performance improvement within individual organizations.

Criteria are needed to ensure that the data selected for analysis are well-defined, consistent, and replicable. Because data are so important to the baseline measures for each goal, BFRL reviewed many potential sources (e.g., journals, technical publications, and electronic media) of baseline-related data/information. This review suggested three criteria which must be met by any data in order to be accepted for analysis. These criteria are:

(1) Published by a reliable, nationally-recognized organization and available to the public;

(2) Updated on a regular basis; and

(3) Able to be normalized to account for changes in the building stock and the level of construction activity.

\subsection{How This Document Helps}

This document is part of a series. As such, it provides perspective on the overall effort to develop baseline measures and measures of progress for each of the seven National

\footnotetext{
${ }^{10}$ If data are available for years in addition to 1994, then these data are collected at the same time as the base year data and used to illustrate trends; these data are also used to compute the associated measures of progress.
} 
Construction Goals. ${ }^{11}$ It also serves to highlight how these measures and their associated metrics can be used to drive performance improvement.

On a deeper level, this document provides step-by-step descriptions of how to construct a well-defined set of baseline measures, their components, and associated metrics for the specific goal of reducing operations, maintenance, and energy costs for educational facilities. Information on data classification, data sources, and data collection and analysis provide the underpinnings for the results presented in this document. It is anticipated that once users of this document have understood the vital role of metrics as a process improvement tool, they will see how the National Construction Goals will benefit both their organization and the US construction industry.

\footnotetext{
${ }^{11}$ Three earlier companion documents focused on National Construction Goals 1, 2, and 7. For information on reductions in delivery time (Goal 1), see Chapman, Robert E., and Roderick Rennison. 1998. An Approach for Measuring Reductions in Delivery Time: Baseline Measures of Construction Industry Practices for the National Construction Goals. NISTIR 6189. Gaithersburg, MD: National Institute of Standards and Technology. For information on reductions in operations, maintenance, and energy costs (Goal 2), see Chapman, Robert E., and Roderick Rennison. 1998. An Approach for Measuring Reductions in Operations, Maintenance, and Energy Costs: Baseline Measures of Construction Industry Practice for the National Construction Goals. NISTIR 6185 . Gaithersburg, MD: National Institute of Standards and Technology. For information on reductions in construction worker illnesses and injuries (Goal 7), see Chapman, Robert E. 2000. An Approach for Measuring Reductions in Construction Worker Illnesses and Injuries: Baseline Measures of Construction Industry Practices for the National Construction Goals. NISTIR 6473. Gaithersburg, MD: National Institute of Standards and Technology.
} 


\section{Overview of the Construction Industry}

The construction industry is a key component of the US economy and is vital to its continued growth. Investment in plant and facilities, in the form of construction activity, provides the basis for the production of products and the delivery of services. Investment in infrastructure promotes the smooth flow of goods and services and the movement of individuals. Investment in housing accommodates new households and allows existing households to expand or improve their housing. Clearly, construction activities affect nearly every aspect of the US economy. ${ }^{12}$

This chapter provides a snapshot of the US construction industry. The chapter contains three sections. Each section deals with a particular topic. The topics progress from general in nature to very specific, as described below.

Section 3.1 presents information on the value of construction put in place to show the size of the construction industry and each of its four sectors. The four sectors, which taken together define the construction industry, are residential, commercial/institutional, industrial, and public works. Data from the past seven years (i.e., 1994 through 2000) are used to highlight the magnitude of construction-related investments in each sector. Data from 1997 are then used to establish the relative shares of construction-related investments for each sector.

Section 3.2 uses information on the commercial/institutional sector both to focus on its importance within the overall construction industry and to define its key components. Information on investment activity, the number of commercial/institutional buildings, and the amount of commercial/institutional floorspace is used to identify both those characteristics that are changing and those that are remaining constant. Educational facilities are a key component of the commercial/institutional sector. Information showing the relative share of construction-related investments in educational facilities vis-à-vis the other components of the commercial/institutional sector is also presented.

Section 3.3 places special emphasis on identifying and detailing the key characteristics of educational facilities. Information detailing key characteristics of educational facilities (e.g., building floorspace and year of construction) is crucial because investments in these facilities affect not only new construction activities, but additions and alterations and maintenance and repair activities as well.

\footnotetext{
${ }^{12}$ Readers interested in learning more about construction statistics, their sources and interpretation, are referred to the document by Rogers (Rogers, R. Mark. 1994. Handbook of Key Economic Indicators. Burr Ridge, IL: Irwin Professional Publishing).
} 


\subsection{Value of Construction Put in Place}

This section provides information on a key indicator of construction activity-the value of construction put in place. Data published by the US Bureau of the Census are used to establish the composition of construction expenditures by type of construction/function (e.g., non-residential/office building). These expenditures are then assigned to the four key construction industry sectors. The reference document used throughout this section is the Current Construction Reports series C30 publication Value of Construction Put in Place. ${ }^{13}$ A brief description of the "C30 report" follows. Special attention is given to the organization of the data in the $\mathrm{C} 30$ report and how these data map into the four key construction industry sectors. The section concludes with tabular and graphical summaries of the value of construction put in place.

Construction expenditures data are published monthly in the Current Construction Reports series C30 publication Value of Construction Put in Place. Construction expenditures refer to actual construction rather than planned or just initiated activity. It is noteworthy that the $\mathrm{C} 30$ report covers both private residential and non-residential construction activities and public sector construction activities.

The value of construction put in place is a measure of the value of construction installed or erected at a site during a given period. For an individual project, this includes: (1) cost of materials installed or erected; (2) cost of labor and a proportionate share of construction equipment rental; (3) contractor's profit; (4) cost of architectural and engineering work; (5) miscellaneous overhead and office costs chargeable to the project on the owner's books; and (6) interest and taxes paid during construction. Expenses do not include the cost of land nor do they include maintenance and repairs to existing structures or service facilities.

The C30 data are compiled via survey and through indirect estimation. In the context of the C30 survey, construction includes the following: (1) new buildings and structures; (2) additions, alterations, conversions, expansions, reconstruction, renovations, rehabilitations, and major replacements (e.g., the complete replacement of a roof or a heating system); (3) mechanical and electrical installations (e.g., plumbing, heating, electrical work, and other similar building services); (4) site preparation and outside construction of fixed structures or facilities (e.g., sidewalks, highways and streets, water supply lines, sewers, and similar facilities which are built into or fixed to the land); (5) installation of boilers, overhead hoists and cranes, and blast furnaces; (6) fixed, largely site-fabricated equipment not housed in a building (e.g., petroleum refineries and chemical plants); and (7) cost and installation of construction materials placed inside a building and used to support production machinery (e.g., concrete platforms, overhead steel girders, and pipes).

${ }^{13}$ US Department of Commerce. 2001. Current Construction Reports: Value of Construction Put in Place. C30. Washington, DC: US Bureau of the Census. 
The data presented in the C30 report are summarized in Tables 3-1 and 3-2. To facilitate comparisons between this report and the C30 report, Tables 3-1 and 3-2 use the same row and column headings as are used in the $\mathrm{C} 30$ report.

Tables 3-1 and 3-2 record annual values for the years 1994 through 2000. Table 3-1 records annual values in millions of constant 1997 dollars. Table 3-2 records annual values in millions of current dollars. ${ }^{14}$ Reference to Table 3-1 reveals that total construction expenditures in real terms have increased modestly over the seven-year period (i.e., from $\$ 571.3$ billion to $\$ 734.3$ billion). When the effects of inflation are included, the rate of increase is more pronounced. Table 3-2 shows total construction expenditures in current dollars.

Tables 3-1 and 3-2 are organized to allow for in-depth analyses of the components/ subcomponents of total construction expenditures. To facilitate such analyses, the data presented in Tables 3-1 and 3-2 are initially divided into two parts: (1) private construction; and (2) public construction.

Private construction contains two major components--residential buildings and nonresidential buildings--plus a number of subcomponents. Both the two major components and the various subcomponents are shown as headings in the first column of Tables 3-1 and 3-2.

The residential buildings component includes new private housing and improvements. New private housing includes new houses, apartments, condominiums, and town houses. New private housing units are classified as " 1 unit" or " 2 or more units." The value of improvements put in place are a direct measure of the value of residential additions and alterations activities.

The non-residential buildings component includes industrial, office buildings, hotels and motels, and "other commercial" (e.g., shopping centers, banks, service stations, warehouses, and other categories). Also falling under the non-residential buildings component are religious, educational, hospital and institutional, and "miscellaneous" nonresidential buildings.

\footnotetext{
${ }^{14}$ Inflation reduces the purchasing power of the dollar over time; deflation increases it. When amounts are stated in actual prices as of the year in which they occur, they are said to be in current dollars. Current dollars are dollars of any one year's purchasing power, inclusive of inflation/deflation. That is, they reflect changes in purchasing power of the dollar from year to year. In contrast, constant dollars are dollars of uniform purchasing power, exclusive of inflation/deflation. Constant dollars indicate what the same good or service would cost at different times if there were no change in the general price level to change the purchasing power of the dollar. For additional information on conducting economic analyses using either constant dollars or current dollars, see Fuller, Sieglinde K., and Stephen R. Petersen. 1996. Life-Cycle Costing Manual for the Federal Energy Management Program. NIST Handbook 135. Gaithersburg, MD: National Institute of Standards and Technology.
} 
Table 3-1. Value of Construction Put in Place in Millions of Constant 1997 Dollars

\begin{tabular}{|c|c|c|c|c|c|c|c|}
\hline \multirow{2}{*}{ Type of Construction } & \multicolumn{7}{|c|}{ Millions of Constant (1997) Dollars } \\
\hline & 1994 & 1995 & 1996 & 1997 & 1998 & 1999 & 2000 \\
\hline Total Construction & 571,271 & 586,538 & 633,670 & 656,630 & 692,876 & 715,203 & 734,273 \\
\hline Private Construction & 439,110 & 449,367 & 489,838 & 501,749 & 537,585 & 553,609 & 576,813 \\
\hline Residential Buildings & 262,659 & 261,129 & 290,341 & 289,014 & 306,260 & 326,447 & 337,030 \\
\hline New Housing Units & 184,639 & 180,951 & 197,385 & 198,063 & 218,041 & 233,527 & 238,508 \\
\hline 1 Unit & 169,156 & 162,066 & 176,395 & 175,179 & 194,119 & 208,020 & 213,225 \\
\hline 2 Units or more & 15,483 & 18,885 & 20,991 & 22,883 & 23,922 & 25,507 & 25,282 \\
\hline Improvements & 78,020 & 80,177 & 92,956 & 90,951 & 88,220 & 92,920 & 98,523 \\
\hline Nonresidential buildings & 132,262 & 144,146 & 158,963 & 172,990 & 185,651 & 183,216 & 189,229 \\
\hline Industrial & 31,829 & 35,919 & 37,409 & 36,739 & 39,410 & 32,655 & 28,881 \\
\hline Office & 24,386 & 27,040 & 28,801 & 34,305 & 41,106 & 43,582 & 50,145 \\
\hline Hotel, motels & 5,111 & 7,508 & 11,270 & 12,898 & 14,423 & 14,916 & 14,764 \\
\hline Other commercial & 41,290 & 45,030 & 49,769 & 51,809 & 52,176 & 53,477 & 55,338 \\
\hline Religious & 4,254 & 4,567 & 4,683 & 5,777 & 6,419 & 7,016 & 7,265 \\
\hline Educational & 5,302 & 5,799 & 6,963 & 8,693 & 9,441 & 9,156 & 10,226 \\
\hline Hospital and institutional & 13,490 & 11,875 & 12,167 & 13,546 & 13,427 & 12,750 & 13,125 \\
\hline Miscellaneous & 6,600 & 6,409 & 7,901 & 9,223 & 9,249 & 9,664 & 9,485 \\
\hline Farm nonresidential & 3,547 & 3,182 & 3,778 & 3,815 & 4,170 & 4,165 & 4,645 \\
\hline Public Utilities & 37,464 & 37,856 & 34,244 & 33,638 & 38,966 & 37,066 & 43,299 \\
\hline Telecommunications & 11,129 & 11,711 & 12,198 & 12,416 & 12,974 & 14,246 & 16,203 \\
\hline Other public utilities & 26,335 & 26,145 & 22,047 & 21,222 & 25,992 & 22,820 & 27,095 \\
\hline Railroads & 3,673 & 3,704 & 4,542 & 4,922 & 5,584 & 4,602 & 3,805 \\
\hline Electric light and power & 16,403 & 14,832 & 11,579 & 11,325 & 12,053 & 13,155 & 19,010 \\
\hline Gas & 5,161 & 6,629 & 4,877 & 4,006 & 7,124 & 3,669 & 3,377 \\
\hline Petroleum pipelines & 1,097 & 981 & 1,048 & 969 & 1,231 & 1,393 & 903 \\
\hline All other private & 3,178 & 3,054 & 2,511 & 2,292 & 2,537 & 2,715 & 2,611 \\
\hline Public Construction & 132,161 & 137,170 & 143,833 & 154,882 & 155,291 & 161,595 & 157,460 \\
\hline Buildings & 54,370 & 60,971 & 65,554 & 71,867 & 71,333 & 72,706 & 74,088 \\
\hline Housing and redevelopment & 4,217 & 4,960 & 5,214 & 5,230 & 4,988 & 5,258 & 4,708 \\
\hline Industrial & 1,611 & 1,592 & 1,435 & 999 & 983 & 866 & 1,044 \\
\hline Educational & 22,388 & 27,219 & 29,528 & 34,385 & 35,273 & 37,176 & 39,225 \\
\hline Hospital & 4,344 & 4,472 & 4,769 & 5,152 & 3,802 & 3,713 & 3,608 \\
\hline Other & 21,809 & 22,727 & 24,608 & 26,100 & 26,288 & 25,693 & 25,503 \\
\hline Highways and streets & 41,145 & 39,711 & 40,759 & 44,105 & 47,228 & 50,098 & 46,905 \\
\hline Military facilities & 2,549 & 3,179 & 2,676 & 2,556 & 2,462 & 1,976 & 2,104 \\
\hline Conservation and development & 6,997 & 6,659 & 6,205 & 5,739 & 5,302 & 5,618 & 5,416 \\
\hline Sewer systems & 9,566 & 8,889 & 10,120 & 10,392 & 9,898 & 10,464 & 9,263 \\
\hline Water supply facilities & 5,110 & 4,971 & 5,802 & 6,419 & 6,649 & 7,114 & 6,239 \\
\hline Miscellaneous public & 12,426 & 12,791 & 12,717 & 13,803 & 12,417 & 13,621 & 13,444 \\
\hline
\end{tabular}


Table 3-2. Value of Construction Put in Place in Millions of Current Dollars

\begin{tabular}{|c|c|c|c|c|c|c|c|}
\hline \multirow{2}{*}{ Type of Construction } & \multicolumn{7}{|c|}{ Millions of Current Dollars } \\
\hline & 1994 & 1995 & 1996 & 1997 & 1998 & 1999 & 2000 \\
\hline Total Construction & 519,539 & 555,591 & 613,535 & 656,630 & 711,759 & 764,233 & 815,414 \\
\hline Private Construction & 399,346 & 425,658 & 474,273 & 501,749 & 552,236 & 591,561 & 640,554 \\
\hline Residential Buildings & 238,874 & 247,351 & 281,115 & 289,014 & 314,607 & 348,826 & 374,274 \\
\hline New Housing Units & 167,919 & 171,404 & 191,113 & 198,063 & 223,983 & 249,536 & 264,864 \\
\hline 1 Unit & 153,838 & 153,515 & 170,790 & 175,179 & 199,409 & 222,280 & 236,788 \\
\hline 2 Units or more & 14,081 & 17,889 & 20,324 & 22,883 & 24,574 & 27,256 & 28,076 \\
\hline Improvements & 70,955 & 75,947 & 90,002 & 90,951 & 90,624 & 99,290 & 109,410 \\
\hline Nonresidential buildings & 120,285 & 136,541 & 153,912 & 172,990 & 190,711 & 195,776 & 210,140 \\
\hline Industrial & 28,947 & 34,024 & 36,220 & 36,739 & 40,484 & 34,894 & 32,073 \\
\hline Office & 22,178 & 25,613 & 27,886 & 34,305 & 42,226 & 46,570 & 55,686 \\
\hline Hotel, motels & 4,648 & 7,112 & 10,912 & 12,898 & 14,816 & 15,939 & 16,396 \\
\hline Other commercial & 37,551 & 42,654 & 48,188 & 51,809 & 53,598 & 57,143 & 61,453 \\
\hline Religious & 3,869 & 4,326 & 4,534 & 5,777 & 6,594 & 7,497 & 8,068 \\
\hline Educational & 4,822 & 5,493 & 6,742 & 8,693 & 9,698 & 9,784 & 11,356 \\
\hline Hospital and institutional & 12,268 & 11,248 & 11,780 & 13,546 & 13,793 & 13,624 & 14,575 \\
\hline Miscellaneous & 6,002 & 6,071 & 7,650 & 9,223 & 9,501 & 10,327 & 10,533 \\
\hline Farm nonresidential & 3,226 & 3,014 & 3,658 & 3,815 & 4,284 & 4,451 & 5,158 \\
\hline Public Utilities & 34,071 & 35,859 & 33,156 & 33,638 & 40,028 & 39,607 & 48,084 \\
\hline Telecommunications & 10,121 & 11,093 & 11,810 & 12,416 & 13,328 & 15,223 & 17,994 \\
\hline Other public utilities & 23,950 & 24,766 & 21,346 & 21,222 & 26,700 & 24,384 & 30,089 \\
\hline Railroads & 3,340 & 3,509 & 4,398 & 4,922 & 5,736 & 4,918 & 4,226 \\
\hline Electric light and power & 14,918 & 14,049 & 11,211 & 11,325 & 12,381 & 14,057 & 21,111 \\
\hline Gas & 4,694 & 6,279 & 4,722 & 4,006 & 7,318 & 3,920 & 3,750 \\
\hline Petroleum pipelines & 998 & 929 & 1,015 & 969 & 1,265 & 1,489 & 1,003 \\
\hline All other private & 2,890 & 2,893 & 2,431 & 2,292 & 2,606 & 2,901 & 2,899 \\
\hline Public Construction & 120,193 & 129,933 & 139,263 & 154,882 & 159,523 & 172,673 & 174,860 \\
\hline Buildings & 49,446 & 57,754 & 63,471 & 71,867 & 73,277 & 77,690 & 82,275 \\
\hline Housing and redevelopment & 3,835 & 4,698 & 5,048 & 5,230 & 5,124 & 5,618 & 5,228 \\
\hline Industrial & 1,465 & 1,508 & 1,389 & 999 & 1,010 & 925 & 1,159 \\
\hline Educational & 20,361 & 25,783 & 28,590 & 34,385 & 36,234 & 39,725 & 43,560 \\
\hline Hospital & 3,951 & 4,236 & 4,617 & 5,152 & 3,906 & 3,968 & 4,007 \\
\hline Other & 19,834 & 21,528 & 23,826 & 26,100 & 27,004 & 27,454 & 28,321 \\
\hline Highways and streets & 37,419 & 37,616 & 39,464 & 44,105 & 48,515 & 53,532 & 52,088 \\
\hline Military facilities & 2,318 & 3,011 & 2,591 & 2,556 & 2,529 & 2,111 & 2,337 \\
\hline Conservation and development & 6,363 & 6,308 & 6,008 & 5,739 & 5,447 & 6,003 & 6,014 \\
\hline Sewer systems & 8,700 & 8,420 & 9,798 & 10,392 & 10,168 & 11,181 & 10,287 \\
\hline Water supply facilities & 4,647 & 4,709 & 5,618 & 6,419 & 6,830 & 7,602 & 6,928 \\
\hline Miscellaneous public & 11,301 & 12,116 & 12,313 & 13,803 & 12,755 & 14,555 & 14,930 \\
\hline
\end{tabular}


Rounding out the private construction component are farm non-residential, public utilities, and "all other private." These are generally of a non-residential nature, but are not part of non-residential buildings. Farm non-residential construction includes structures such as barns, storage houses, and fences. Land improvements such as leveling, terracing, ponds, and roads are also a part of this subcomponent. Privately owned public utilities construction is categorized by industry rather than function of the building or structure. This subcomponent includes expenditures made by utilities for telecommunications, railroads, petroleum pipelines, electric light and power, and natural gas. "All other private" includes privately owned streets and bridges, sewer and water facilities, airfields, and similar construction.

For public construction, there are two major components--building and non-building. Both the two major components and the various subcomponents are shown as headings in the first column of Tables 3-1 and 3-2. The building component contains subcomponents similar to those for private construction, with educational buildings being the largest subcomponent. Expenditures for the non-building component overwhelmingly consist of outlays for highways and streets, with sewer systems being a distant second subcomponent.

To get the sector totals, each subcomponent was assigned to a sector and summed. The sector assignments are identical to those used in Chapman and Rennison. ${ }^{15}$ The sector totals and the overall total are recorded in Tables 3-3 and 3-4. Reference to the tables reveals that sector totals vary considerably, with residential being the largest and industrial the smallest.

Table 3-3. Value of Construction Put in Place: Sector Totals and Sum Total in Millions of Constant 1997 Dollars ${ }^{16}$

\begin{tabular}{|l|c|c|c|c|c|c|c|}
\hline \multirow{2}{*}{ Sector } & \multicolumn{7}{|c|}{ Value of Construction Put in Place (\$ Millions) } \\
\cline { 2 - 8 } & 1994 & 1995 & 1996 & 1997 & 1998 & 1999 & 2000 \\
\hline Residential & 266,876 & 266,089 & 295,555 & 294,244 & 311,248 & 331,705 & 341,738 \\
\hline $\begin{array}{l}\text { Commercial/ } \\
\text { Institutional }\end{array}$ & 152,521 & 165,828 & 184,237 & 205,703 & 215,774 & 221,308 & 233,329 \\
\hline Industrial & 33,440 & 37,511 & 38,844 & 37,738 & 40,393 & 33,521 & 29,925 \\
\hline Public Works & 118,434 & 117,111 & 115,034 & 118,944 & 125,459 & 128,671 & 129,280 \\
\hline $\begin{array}{l}\text { Total - All } \\
\text { Sectors }\end{array}$ & 571,271 & 586,539 & 633,670 & 656,629 & 692,874 & 715,205 & 734,272 \\
\hline
\end{tabular}

15 Chapman, Robert E., and Roderick Rennison. 1998. An Approach for Measuring Reductions in Operations, Maintenance, and Energy Costs: Baseline Measures of Construction Industry Practices for the National Construction Goals. NISTIR 6185. Gaithersburg, MD: National Institute of Standards and Technology.

${ }^{16}$ Note that due to rounding the values entered in the "Total - All Sectors" row in Table 3-3, differ slightly from the values entered in the "Total Construction" row in Table 3-1. 
Table 3-4. Value of Construction Put in Place: Sector Totals and Sum Total in Millions of Current Dollars ${ }^{17}$

\begin{tabular}{|l|c|c|c|c|c|c|c|}
\hline \multirow{2}{*}{ Sector } & \multicolumn{7}{|c|}{ Value of Construction Put in Place (\$ Millions) } \\
\cline { 2 - 8 } & 1994 & 1995 & 1996 & 1997 & 1998 & 1999 & 2000 \\
\hline Residential & 242,709 & 252,049 & 286,163 & 294,244 & 319,731 & 354,444 & 379,502 \\
\hline $\begin{array}{l}\text { Commercial/ } \\
\text { Institutional }\end{array}$ & 138,710 & 157,078 & 178,383 & 205,703 & 221,654 & 236,482 & 259,113 \\
\hline Industrial & 30,412 & 35,532 & 37,609 & 37,738 & 41,494 & 35,819 & 33,232 \\
\hline Public Works & 107,709 & 110,932 & 111,379 & 118,944 & 128,878 & 137,492 & 143,567 \\
\hline $\begin{array}{l}\text { Total - All } \\
\text { Sectors }\end{array}$ & 519,540 & 555,591 & 613,534 & 656,629 & 711,757 & 764,237 & 815,414 \\
\hline
\end{tabular}

Table 3-3 reveals that the commercial/institutional sector is the only sector to have grown consistently in real terms over the entire seven-year period. In real terms, expenditures in the commercial/institutional sector grew from \$152.5 billion in 1994 to \$233.3 billion in 2000, an increase of almost $55 \%$. Real expenditures for two of the four sectors, industrial and public works, were essentially constant over the same seven-year period. Real expenditures for the residential sector exhibited a cyclical pattern.

The data contained in Tables 3-3 and 3-4 provide the basis for calculating each sector's relative share of total construction expenditures. Each sector's relative share of total construction expenditures is shown graphically in pie chart form in Figure 3-1. It was constructed using 1997 data from Table 3-4 (i.e., current dollar expenditures). Figure 3-1 reveals that in 1997 the commercial/institutional sector accounted for 31 percent of total construction expenditures (i.e., $31 \%$ of $\$ 656.6$ billion). The commercial/institutional sector's relative share of total construction expenditures is exceeded only by the residential sector, which constitutes $45 \%$ of the total. In addition, the commercial/institutional sector's relative share exceeds the combined total for the industrial and public works sectors.

\subsection{Overview of the Commercial/Institutional Sector}

The commercial/institutional sector, defined in economic terms, consists of establishments that provide services. Defined in this way, the commercial/institutional sector is extremely varied. It includes office buildings, service businesses (e.g., retail and wholesale stores, hotels and motels, restaurants, and hospitals), as well as a wide range of facilities that would not be considered "commercial" in a traditional sense (e.g., public schools, correctional institutions, and religious and fraternal organizations).

\footnotetext{
${ }^{17}$ Note that due to rounding the values entered in the "Total-All Sectors" row in Table 3-4 differ slightly from the values entered in the "Total Construction" row of Table 3-2.
} 
Figure 3-1. 1997 Breakdown of \$657 Billion Construction Market

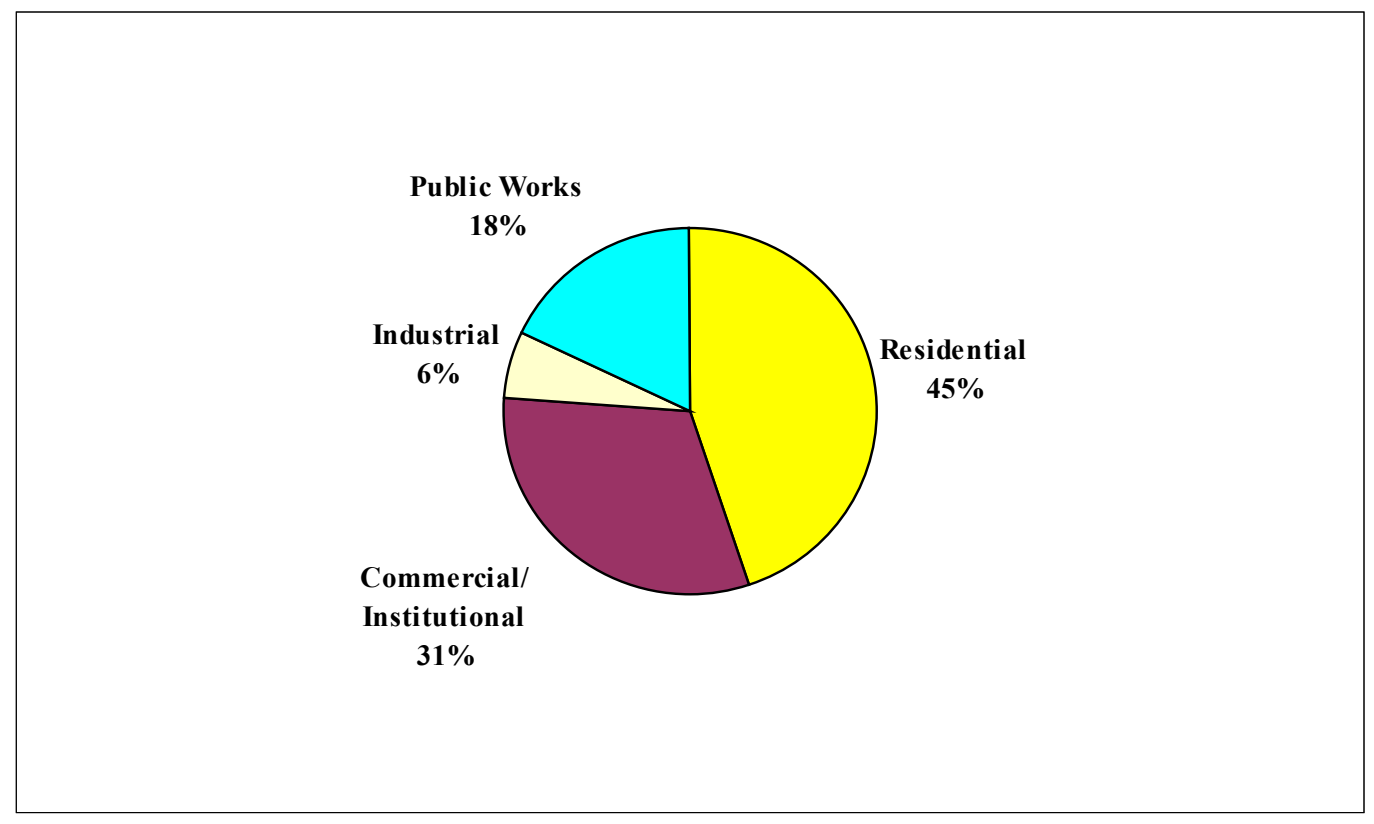

Expenditures by establishments in the commercial/institutional sector for the built environment include construction expenditures (e.g., new construction and additions and alterations) as well as expenditures for facility operations, for maintenance and repair activities, and for energy. Consequently, it is instructive to first define what is included in each type of expenditure and then examine the characteristics of commercial/ institutional buildings that affect these expenditures.

Construction expenditures include both new construction activities and additions and alterations.

New construction activities include the complete original building of structures and essential service facilities and the initial installation of integral equipment (e.g., elevators and plumbing, heating, and air-conditioning supplies and equipment).

Additions and alterations include construction work that adds to the value or useful life of an existing building or structure, or which adapts a building or structure to a new or different use. Included are major replacements of building systems (e.g., installation of a new roof or heating system).

Facility operations include all non-process or end-product related activities required to operate a building or structure (e.g., water consumption, trash removal/environmental costs, cleaning services/janitorial, and security services/life safety costs), with the exception of maintenance and repair activities and energy. In some cases, fixed operations components may also be included (e.g., real estate and other taxes, insurance, and leasing expenses). 
Maintenance and repair activities include incidental construction work that keeps a building or structure in ordinary working condition.

Energy is defined as including all non-process or end-product related energy consumption required to operate a building or structure. Energy consumption can be categorized by energy source (e.g., electricity, gas, and oil) and by end-use (e.g., space heating, cooling, and lighting).

Construction expenditures in 1997 for the commercial/institutional sector were $\$ 205.7$ billion in current dollars (see Table 3-4). Total expenditures include expenditures from subcomponents listed under both the "private construction" and "public construction" headings in Tables 3-1 and 3-2. The subcomponents included under the private construction heading are: office, hotels and motels, other commercial, religious, educational, hospital and institutional, miscellaneous, and farm non-residential. The subcomponents included under the public sector heading are: educational, hospital, and other. Because the commercial/institutional sector is so varied, it is useful to group these subcomponents into a small number of key components. For convenience, these subcomponents are grouped into four key components, three of which are fairly homogeneous. The four key components are: educational, office, hospital, and other. The relative share of the overall commercial/institutional sector's construction expenditures for each of the four key components is shown graphically in pie chart form in Figure 3-2. It was constructed using 1997 data from Table 3-2 (i.e., current dollar expenditures). Reference to Figure 3-2 reveals that in 1997 the educational facilities component accounted for 21 percent of the commercial/institutional sector's construction expenditures.

A report ${ }^{18}$ by Chapman and Rennison included information on operations, maintenance, and energy costs for the commercial/institutional sector. Wherever possible, Chapman and Rennison normalized data on a per unit area basis. If the data were sufficiently detailed, as was the case with energy data, they were classified into "bins" within which certain characteristics were homogeneous (e.g., building type, size, and age) and then normalized on a per unit area basis. Although there are a number of data sets which allow such in-depth analyses, the data associated with the Department of Energy's (DOE's) Commercial Building Energy Consumption Survey (CBECS) is the source of preference for summarizing the characteristics of the commercial/institutional sector's stock of buildings.

${ }^{18}$ Chapman and Rennison, An Approach for Measuring Reductions in Operations, Maintenance, and Energy Costs. 
Figure 3-2. 1997 Breakdown of \$206 Billion Commercial/Institutional Sector

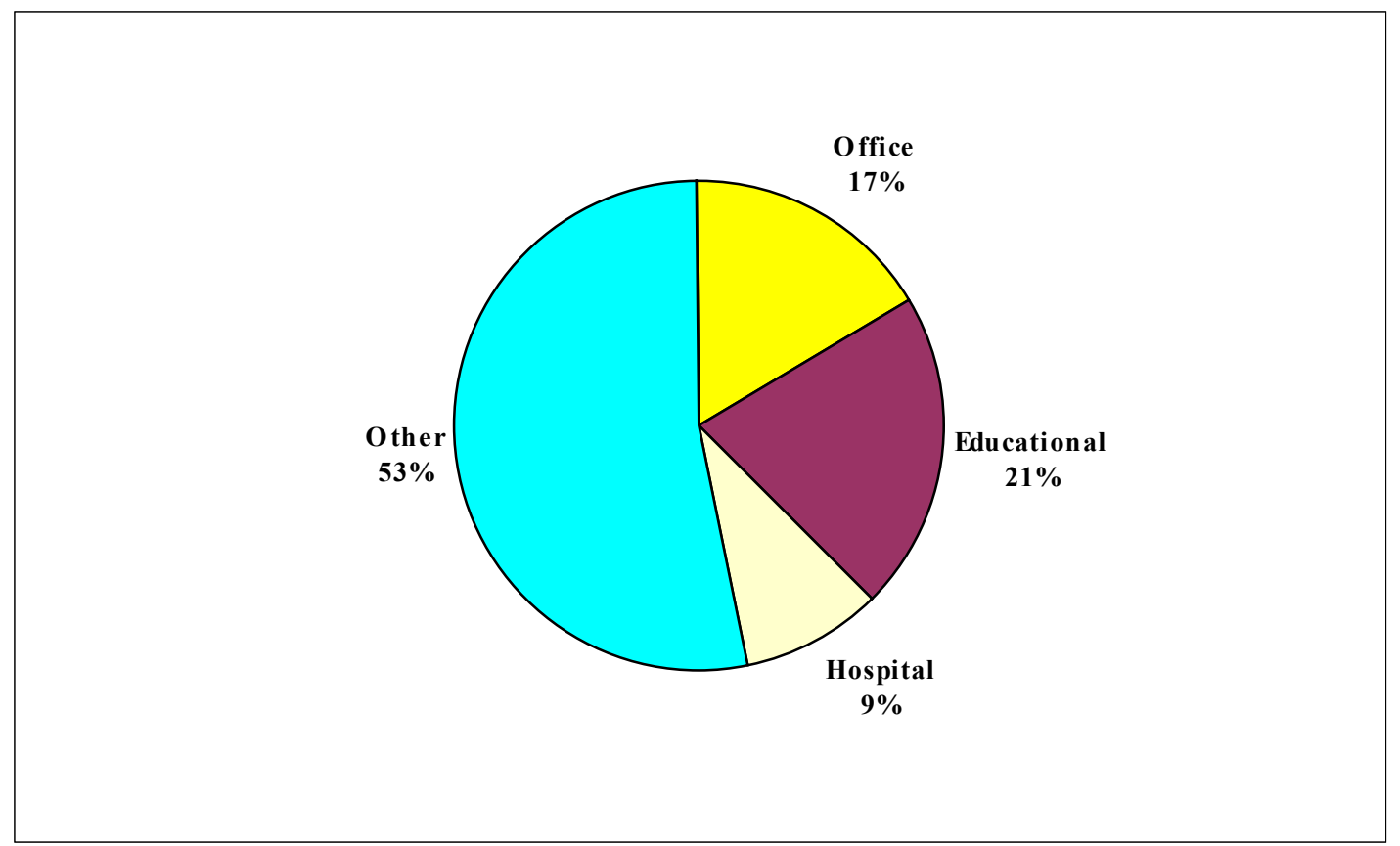

The CBECS collects information on physical characteristics of commercial buildings, building use and occupancy patterns, equipment use, conservation features and practices, and types and uses of energy in buildings. The survey also collects information on the amount of energy consumed and the costs for energy in commercial buildings. The survey is conducted in two stages, the Building Characteristics Survey and the Energy Suppliers Survey. The focus of this section and the next is on the Building Characteristics Survey. Readers interested in the CBECS and its associated micro-data files are referred to Section 4.1.

The most recent DOE Commercial Buildings Characteristics report ${ }^{19}$ provides detailed information on the size, age, and other characteristics of commercial/institutional buildings. In 1995, there were 4.58 million commercial buildings and 5.46 billion square meters (58.78 billion square feet) of commercial floorspace in the United States. The mean size of all commercial buildings was $1,193 \mathrm{~m}^{2}\left(12,840 \mathrm{ft}^{2}\right) .{ }^{20}$ The DOE report grouped buildings into eight size categories and into eight age categories. The vast majority of commercial buildings were found in the smallest size categories, with more than half in the smallest category and three quarters in the two smallest categories. Most commercial buildings, once constructed, are expected to last for decades or longer. New buildings are constructed each year and older buildings are demolished, but the commercial buildings stock at any point in time is dominated by older buildings. More

\footnotetext{
${ }^{19}$ US Department of Energy. 1997. Commercial Buildings Characteristics 1995. DOE/EIA-E024695. Washington, DC: Energy Information Administration.

${ }^{20}$ Values of floorspace expressed in square meters are denoted by $\mathrm{m}^{2}$. Values of floorspace expressed in square feet are denoted by $\mathrm{ft}^{2}$.
} 
than 70 percent of all commercial buildings and total floorspace were constructed prior to 1980, and more than $50 \%$ of buildings and floorspace were constructed prior to 1970 .

The DOE report also examined whether any changes in major characteristics had occurred between 1989 and 1995. The report concluded that the profiles of major characteristics of commercial buildings showed no statistically significant changes from 1989 to 1992 to 1995 , the years in which the last three surveys were conducted. ${ }^{21}$ Significant changes between surveys would occur if characteristics in the newest buildings (i.e., those constructed since the previous survey) were quite different, or if changes were made to buildings in the existing stock. However, each three-year increment of new buildings and floorspace was generally small compared to all buildings and floorspace in a given category and the changes that did occur were not great enough to be statistically significant.

The profiles of major characteristics which showed no significant changes included the total number of buildings, the total amount of floorspace, the distribution of floorspace by principal building activity (e.g., office buildings), the distribution of buildings by size of building, and the distribution of floorspace by census region. Consequently, the total floorspace associated with each of the major components shown in Figure 3-2 has remained constant over the same period of time. If this trend continues, then total floorspace for each key component will continue to remain constant. It is important to note that during the period covered by the last survey the commercial/institutional sector experienced steady growth in construction expenditures relative to the rest of the construction industry. Even during this period of growth in construction expenditures, total floorspace in the commercial/institutional sector remained constant.

\subsection{Characteristics of Educational Facilities}

In 1995, there were 309,000 educational facilities in the United States. Collectively, these 309,000 educational facilities had 719 million $\mathrm{m}^{2}\left(7,740\right.$ million $\left.\mathrm{ft}^{2}\right)$ of floorspace. Educational facilities had a mean size of 2,453 $\mathrm{m}^{2}\left(25,100 \mathrm{ft}^{2}\right) .{ }^{22}$ Although there are a number of very large educational facilities, the key category of educational facilities is actually dominated by smaller buildings. On the other hand, the mean size of all educational facilities is nearly twice the mean size of all commercial/institutional buildings $\left(1,193 \mathrm{~m}^{2}\left(12,840 \mathrm{ft}^{2}\right)\right)$.

Figures 3-3 through 3-8 provide detailed snapshots of the nation's stock of educational facilities. In each figure, information is classified along one of two major dimensions, either by building size, measured in terms of total floorspace, or by building age, measured in terms of year of construction. Each set of figures (e.g., Figures 3-3, 3-4, and 3-5) uses the same bar chart format to facilitate comparisons of characteristics.

Figures 3-3, 3-4, and 3-5 record the distribution of the number of educational facilities and total educational floorspace by building size. All three figures use the same eight

${ }^{21}$ Commercial Buildings Characteristics 1995, p. vii. and p.10.

${ }^{22}$ Ibid., p. 5. 
size categories specified in the DOE report. The DOE size categories are specified in customary units; they range from $1,001 \mathrm{ft}^{2}$ to $5,000 \mathrm{ft}^{2}\left(93.0 \mathrm{~m}^{2}\right.$ to $\left.464.5 \mathrm{~m}^{2}\right)$ for the smallest size category to over $500,000 \mathrm{ft}^{2}$ (over $46,451.5 \mathrm{~m}^{2}$ ) for the largest size category. The eight size categories, as defined in this section, are used throughout this report. To facilitate reference to the DOE report, customary units are shown on the left-hand axis and SI units on the right-hand axis of each figure.

Figure 3-3 records the distribution of the number of educational facilities by building size. Figure 3-3 shows clearly why smaller buildings dominate the key category of educational facilities. Nearly one third of the stock of educational facilities $(100,000$ of $309,000)$ is contained in the smallest size category, and more than one half $(160,000$ of 309,000 ) in the two smallest size categories. By contrast, only 12,000 buildings are contained in the three largest size categories, and less than 1,000 in the largest category.

Figure 3-4 shows a very different snapshot of the stock of educational facilities than was seen in Figure 3-3. Figure 3-4 records the distribution of total floorspace by building size. When the total floorspace associated with each size category is tabulated, the floorspace in the two smallest size categories and the largest size category are much less than the intermediate size categories.

Figure 3-5 introduces an additional characteristic, the number of floors in the building. This characteristic serves to sharpen the distinctions between the buildings in each size category. Figure 3-5 uses the same classification scheme as employed in the DOE report. DOE grouped educational facilities into one of five categories, based on the number of floors. These categories are one floor, two floors, three floors, four to nine floors, and ten or more floors. Each floor category is coded by shading; a legend is provided on the figure to match the floor category to a specific bar in each of the eight size categories. Figure 3-5 shows clearly how the distribution of total floorspace shifts as building size increases. For example, buildings with one and two floors dominate total floorspace in the three smaller size categories. As building size increases, the total floorspace in buildings with four or more floors rises quickly and then remains fairly steady.

Figures 3-6, 3-7, and 3-8 record the distribution of the number of educational facilities and total educational floorspace by year of construction. In all three figures, the years of construction are grouped into seven multi-year periods (i.e., categories). It is important to note that these seven year of construction categories differ from the eight year of construction categories specified in the DOE report. This is because the last two DOE year of construction categories have been combined. The last two DOE year of construction categories were 1990 to 1992 and 1993 to 1995 . These categories were combined to form the 1990 to 1995 year of construction category. The year of construction categories used are 1919 or before, 1920 to 1945,1946 to 1959,1960 to 1969,1970 to 1979,1980 to 1989 , and 1990 to 1995 . The seven year of construction categories, as defined in this section, are used throughout this report. 
Figure 3-3. Total Number of Educational Facilities by Size Category: 1995

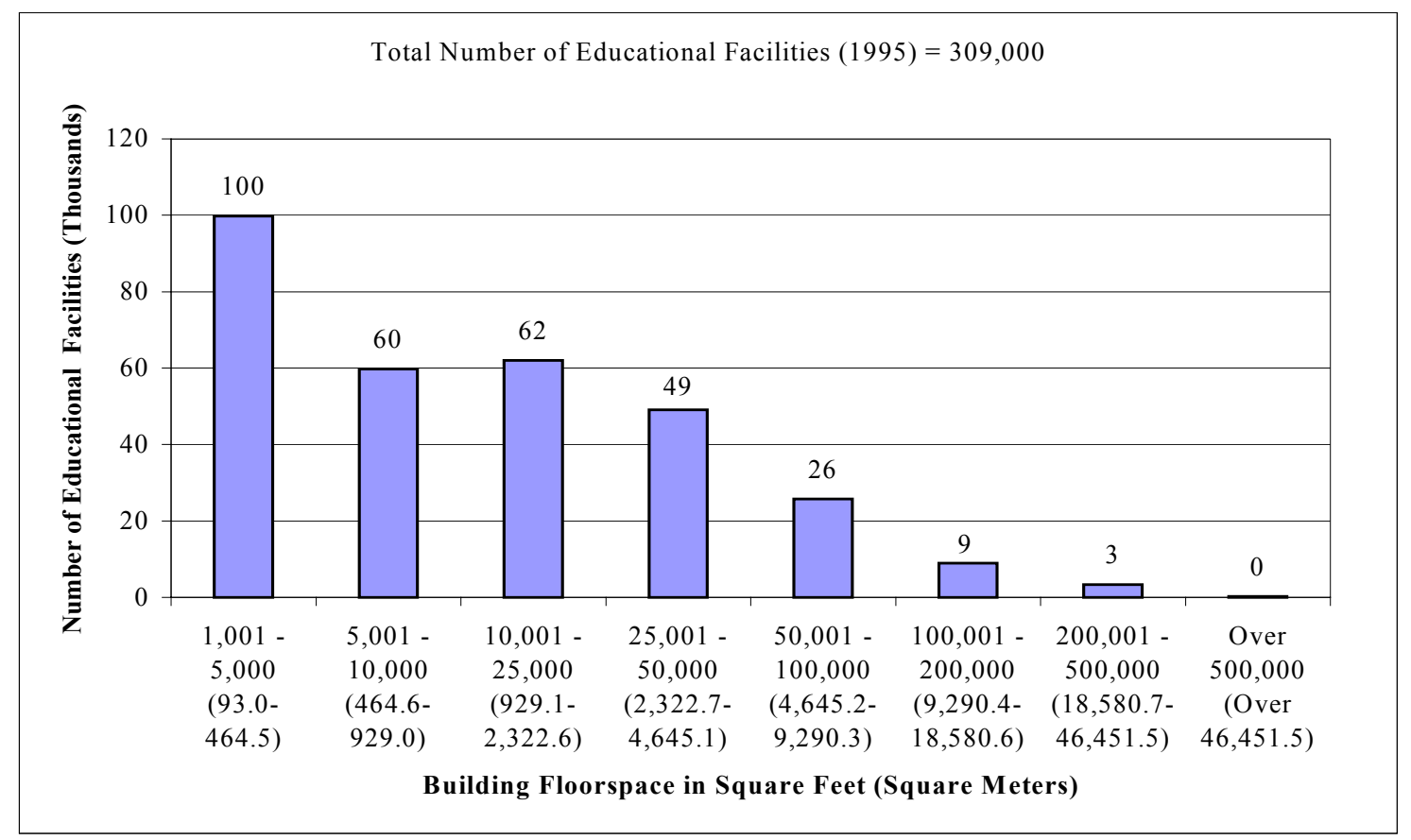

Figure 3-4. Total Educational Floorspace by Building Size Category: 1995

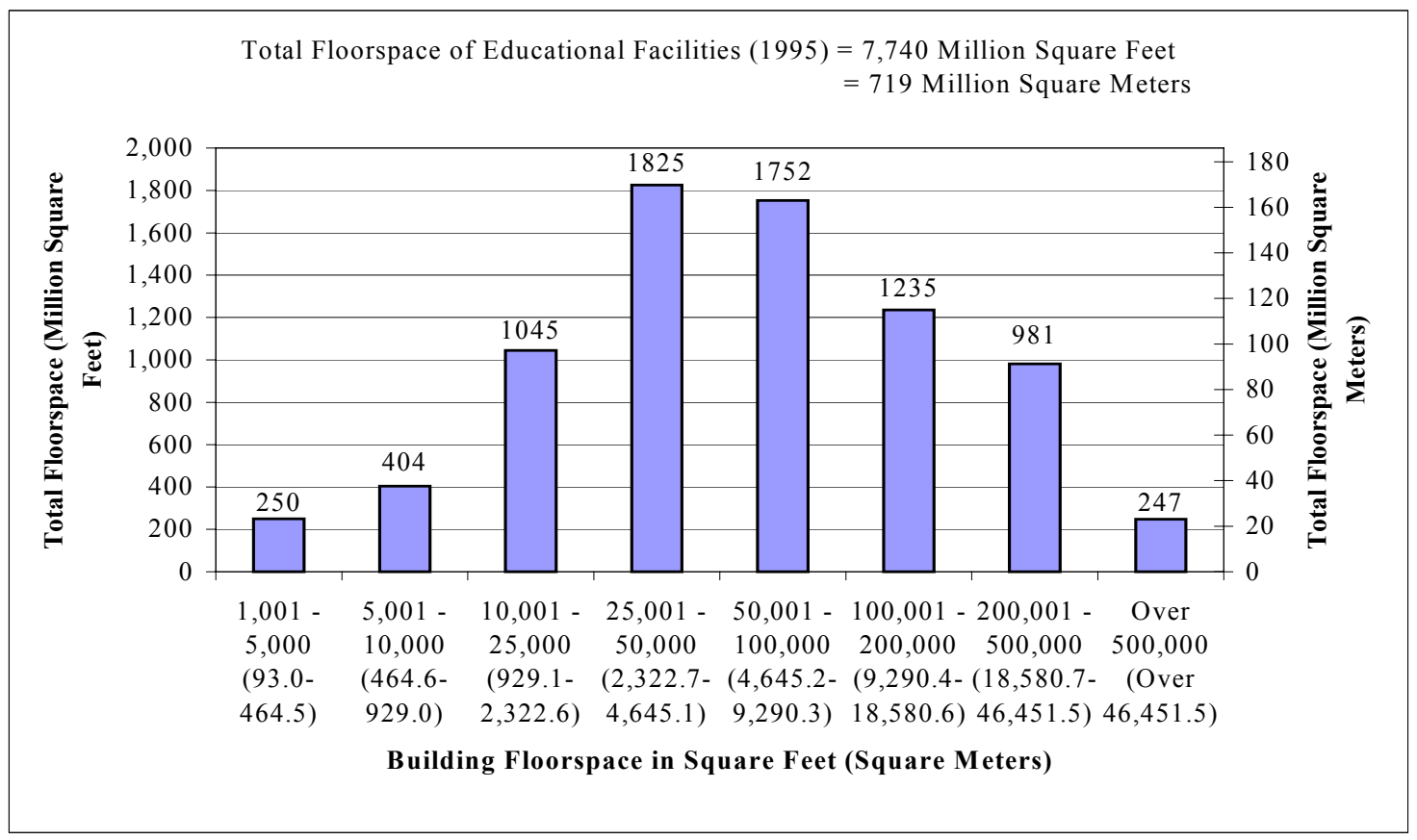


Figure 3-5. Total Educational Floorspace by Building Size Category and Number of Floors: 1995

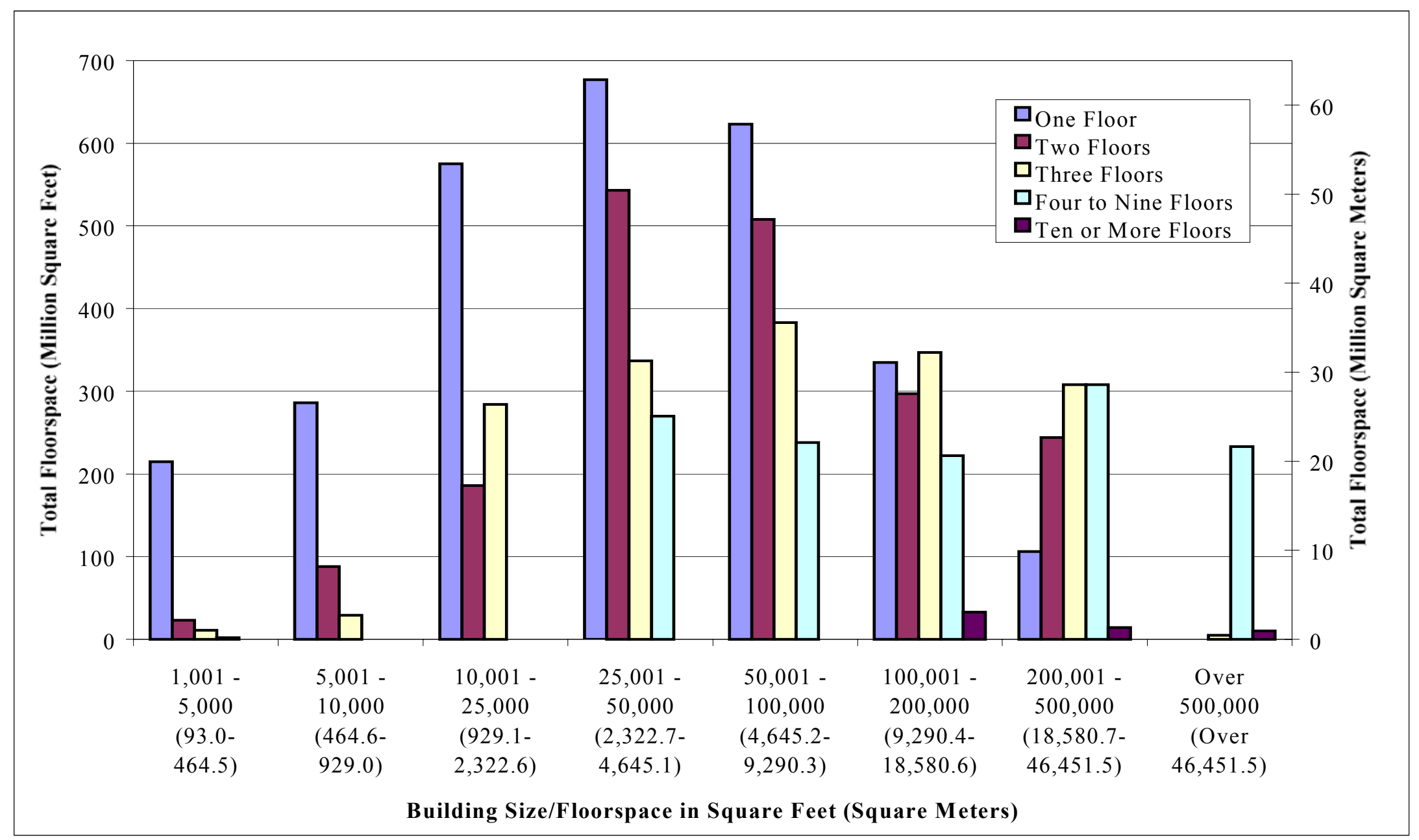


Figure 3-6 records the distribution of the number of educational facilities by year of construction. Figure 3-6 shows that five sixths of the stock of educational facilities $(249,000$ of 309,000$)$ has been constructed since World War II.

Figure 3-7 records the distribution of floorspace by year of construction. Note that approximately one half of all educational floorspace was constructed between 1946 and 1969. In addition, educational floorspace put in place has been declining since 1970.

Figure 3-8 introduces information on the number of floors. Begin by comparing Figure 3-8 with Figure 3-5. Recall that Figure 3-5 showed a definite shift in the distribution of total floorspace among the floor categories as building size increased. When year of construction is the characteristic under investigation, a different pattern emerges. Basically, since 1946, the distribution of floorspace among the floor categories within a given year of construction category is skewed towards low-rise buildings. For each year of construction category since 1946, total floorspace for one and two floor buildings tends to exceed the floorspace for educational facilities with three or more floors. Although this outcome may seem puzzling at first, it is easily rationalized. In any extended period, say 1960 to 1969 , the distribution of building sizes tends to take on the characteristics (e.g., shape) of the distribution of building sizes for the overall population. Thus the characteristics of the building size distribution for the 1960 to 1969 year of construction category would be similar to Figure 3-5, the distribution for the overall population. Consequently, summing across building size for each floor category would produce a declining staircase-type distribution with a relatively higher value of total floorspace for low-rise buildings. 
Figure 3-6. Total Number of Educational Facilities by Year of Construction: 1995

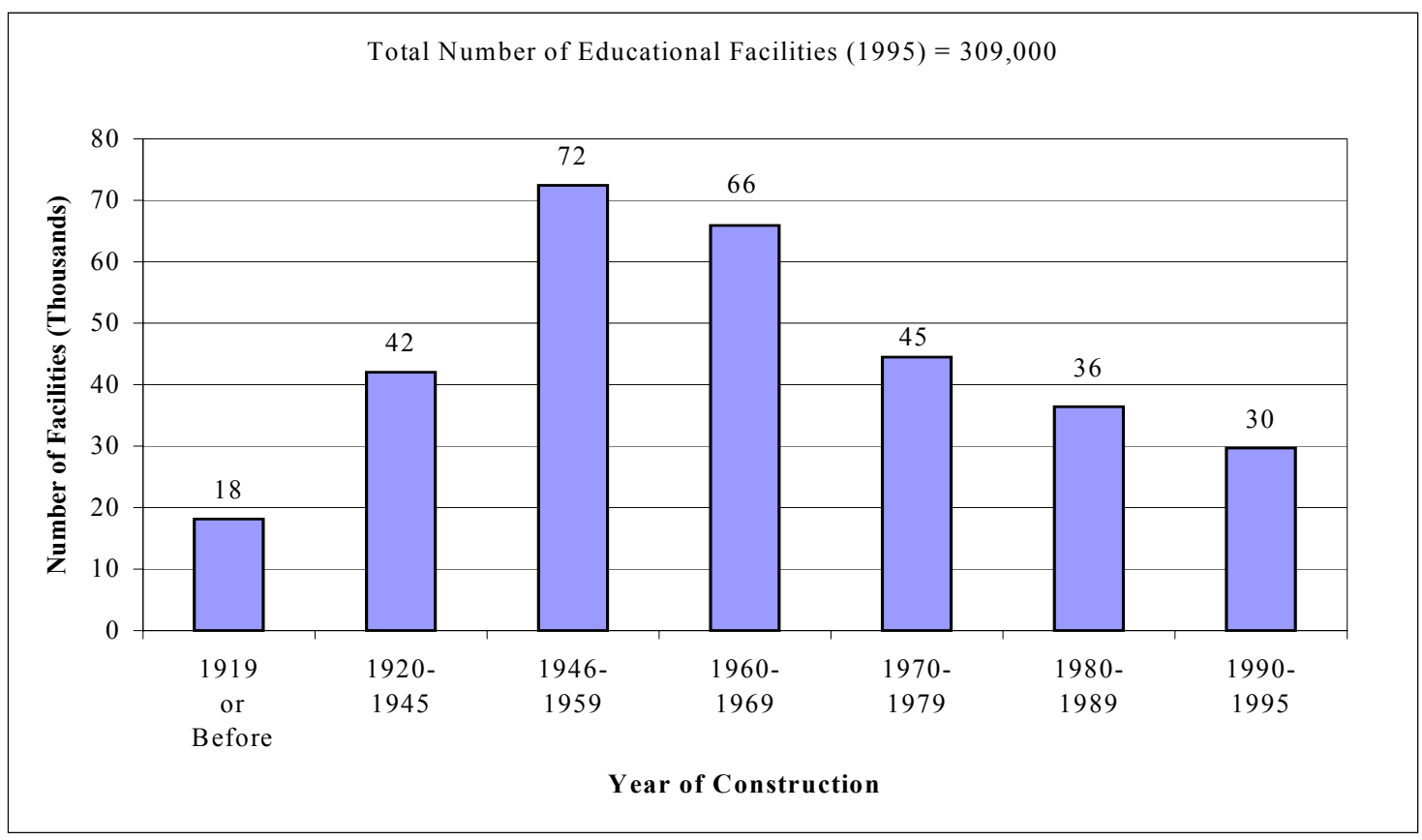

Figure 3-7. Total Educational Floorspace by Year of Construction: 1995

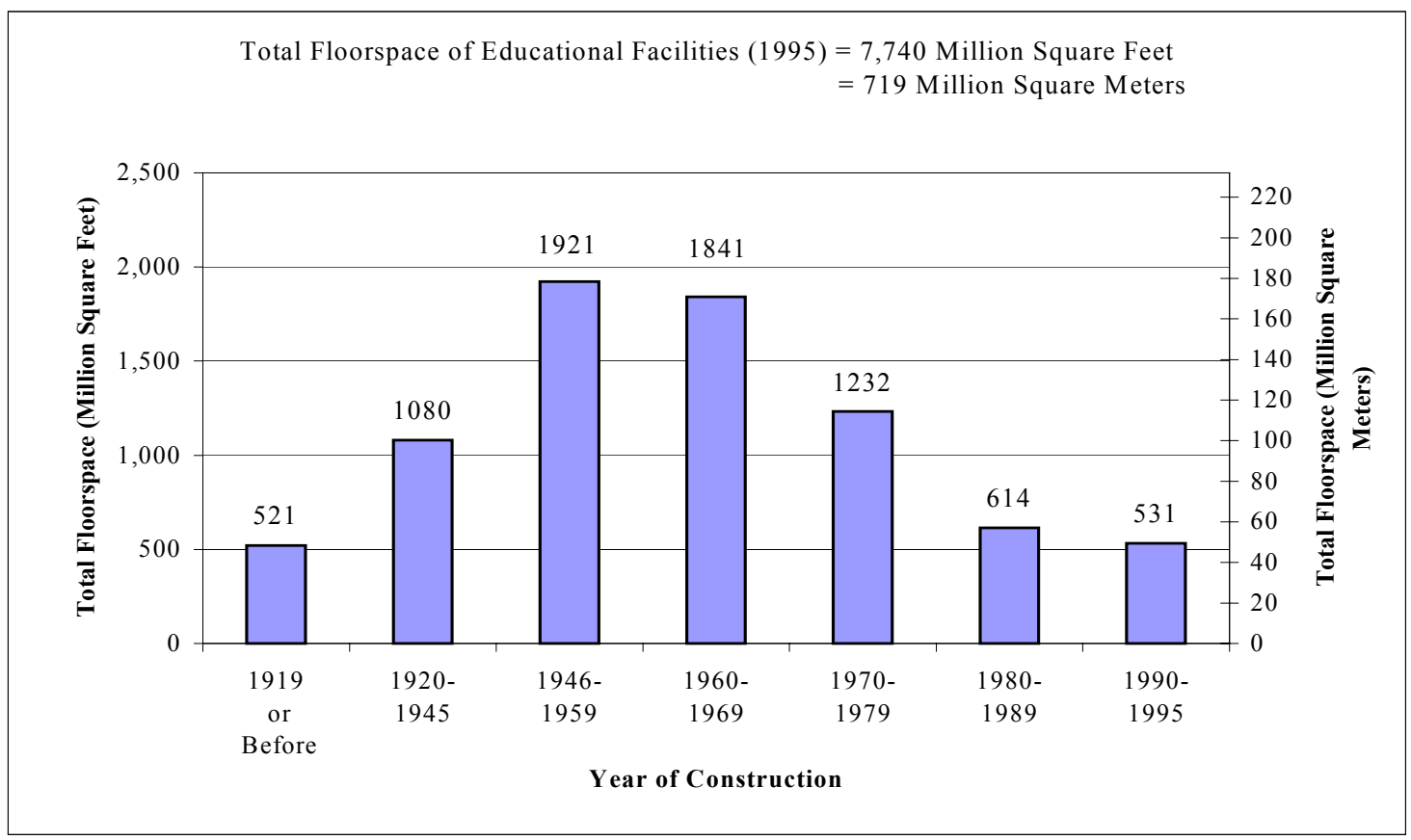


Figure 3-8. Total Educational Floorspace by Year of Construction and Number of Floors: 1995

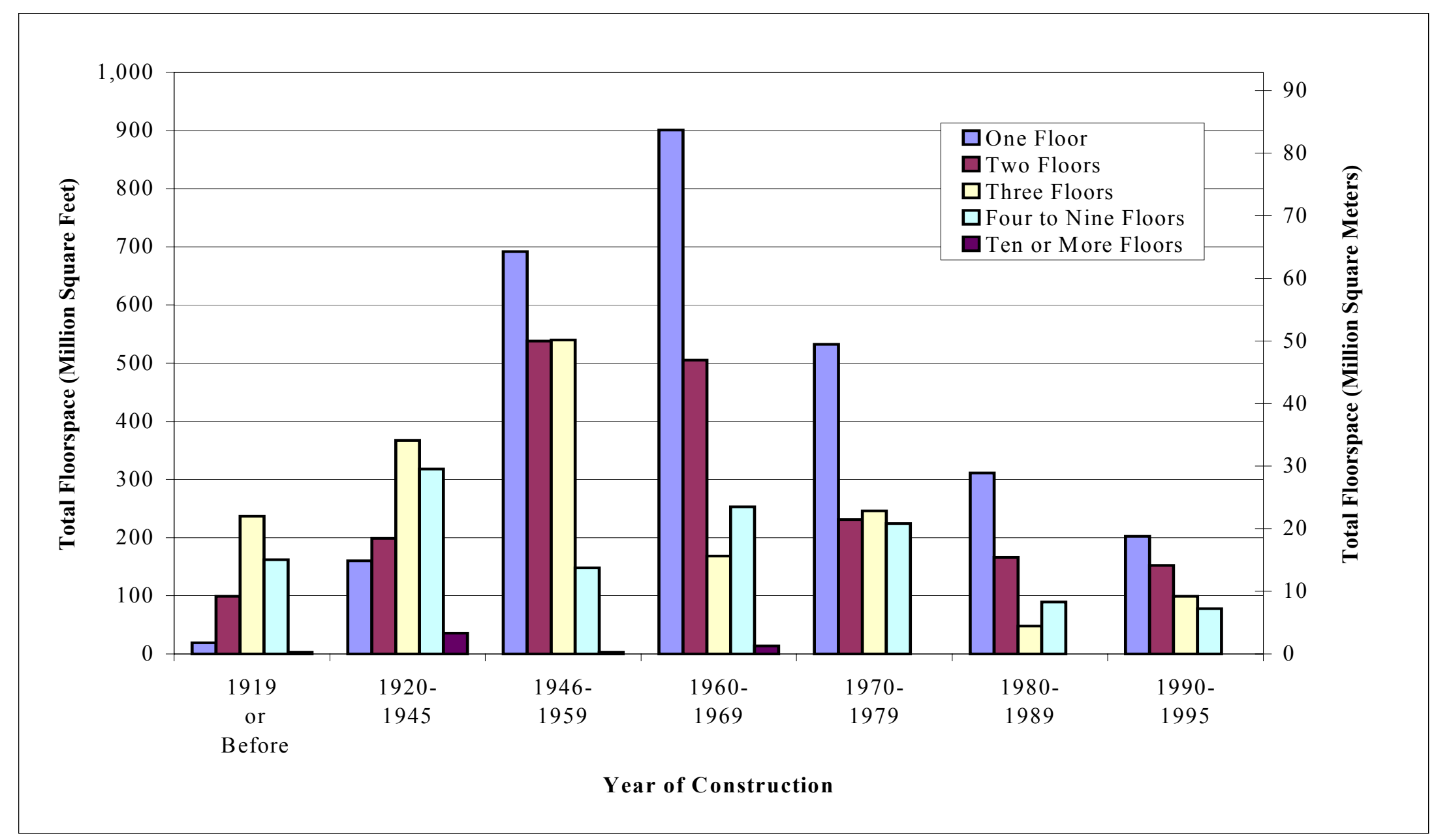




\section{OM\&E Measures for Educational Facilities}

This chapter traces the development of the OM\&E baseline measures for educational facilities. Data sources are described and matched to the key types of educational facilities (i.e., K-12 and colleges and universities). The OM\&E baseline measures are then derived from the source data. Information on energy conservation features is also included. The chapter concludes with a summary of the various OM\&E baseline measures for educational facilities.

\subsection{Data Considerations: Sources, Availability, and Constraints}

Preliminary data searches for the commercial/institutional sector indicated that there were a variety of organizations that are carrying out systematic surveys of selected types of educational facilities, but that there are few surveys which cover all types of educational facilities. The most detailed survey of educational facilities which has been located by the author is carried out by the Energy Information Administration (EIA), a part of the US Department of Energy (DOE). Information from EIA, and other selected organizations, was examined in detail to determine how it might best be used to develop baseline measures for educational facilities. The principal data sources that are used in this document are described below.

\section{Data from the Energy Information Administration}

The DOE Commercial Buildings Energy Consumption Survey (CBECS) is used to establish the sources for two key data items: (1) the national average energy cost per $\mathrm{m}^{2}$ (per $\mathrm{ft}^{2}$ ); and (2) the rates of utilization of energy conserving features and practices. CBECS is a national sample survey that collects energy-related building characteristics and consumption and expenditure data for US commercial buildings. CBECS was first conducted in 1979 and then triennially since 1983.

In the 1995 CBECS, there were 6,590 sampled buildings of which 5,766 were successfully interviewed. Energy-related characteristics of the buildings are obtained in an on-site personal interview with the building managers, owners, or tenants during the Commercial Buildings Characteristics Survey. Energy consumption and expenditures information are obtained from the energy suppliers to the responding buildings during the Energy Suppliers Survey. The CBECS defines commercial buildings as enclosed roofed and walled structures used predominantly for commercial purposes with floorspace greater than 1,000 $\mathrm{ft}^{2}$. This definition includes buildings such as schools, health care buildings, and religious institutions, as well as office buildings and retail stores.

The survey includes characteristics of each building sampled. One of these characteristics, principal building activity, is used to separate educational facilities from other types of commercial buildings. Readers interested in a detailed description of the 
1995 CBECS are referred to the recent report by the Energy Information Administration. $^{23}$

The information presented in this chapter is derived from data contained in the CBECS Public Use Files. The Public Use Files are microdata files that contain 5,766 records, representing commercial buildings from the 50 States and the District of Columbia. Each record corresponds to a single sampled building and contains information for that building about the building size, year constructed, types of energy used, energy-using equipment, energy consumption and expenditures, conservation features and energy management practices, and energy used for nine end uses. The nine end uses are space heating, cooling, ventilation, lighting, water heating, cooking, refrigeration, office equipment, and other.

The CBECS sample was designed so that survey responses could be used to estimate characteristics of the entire commercial buildings stock nationwide. In order to arrive at national estimates from the CBECS sample, DOE calculated base-sampling weights for each building. Therefore, a building with a base weight of 1,000 represents itself and 999 similar, but unsampled buildings in the total building stock. The base weight is further adjusted to account for nonresponse bias. In order to obtain a weighted estimate, each sample building's value must be multiplied by the building's weight.

\section{Data from APPA: The Association of Higher Education Facilities Officers}

APPA is an organization with more than 4,500 members representing learning institutions across the US and Canada, with universities and colleges representing the largest segment of the membership. APPA promotes the effective operation and maintenance of educational facilities through education and technical support of facility managers and others in the profession. The APPA 1993-94 Comparative Costs and Staffing Report for College and University Facilities (the second biennial report), ${ }^{24}$ provides detailed information on facilities management costs and staffing information. It is based on 516 surveys carried out for the 1993-94 fiscal year. Data are presented which describe operations, maintenance, and energy costs for facilities, sorted by facility funding source, type, geographic location, and size of student population. Data from APPA are available through its Internet site (URL: http://www.appa.org) or through paper publications.

\section{American School \& University (AS\&U) Magazine}

$A S \& U$ Magazine serves chief administrators, facility managers, business officials, purchasing directors, and architects. The focus of the magazine is on facilities/business

\footnotetext{
${ }^{23}$ US Department of Energy. 1998. A Look at Commercial Buildings in 1995: Characteristics, Energy Consumption, and Energy Expenditures. DOE/EIA-0625(95). Washington, DC: Energy Information Administration.

${ }^{24}$ The Association of Higher Education Facilities Officers. 1995. 1993-94 Comparative Costs and Staffing Report for Colleges and University Facilities. Alexandria, VA: The Association of Higher Education Facilities Officers.
} 
administration, including public and private schools and colleges and universities. AS\&U also conducts and publishes an annual survey of maintenance and operations costs. Data from the 1996 AS\&U Maintenance \& Operations Case Study ${ }^{25}$ were used to produce "summary" measures of OM\&E costs for K-12 facilities and for college and university facilities.

\section{Data from Whitestone Research}

The Whitestone Building Maintenance and Repair Cost Reference 1996 is the second of a series of annual reports produced by Whitestone Research ${ }^{26}$ which presents estimates of 50 year maintenance cost profiles for 24 different building models. Example building types are elementary schools, fast food restaurants, motels, auto service garages, offices, supermarkets, and movie theaters. These cover a good portion of the commercial/ institutional sector. The profile for each model includes a building description, a list of major building components, and forecasts of maintenance and repair costs at various levels of aggregation over the service life of the building. These can be adjusted for selected metropolitan areas, and modified to include different building components. The Whitestone Reports are available in paper form from Whitestone Research.

\section{Data from Other Sources}

- National Clearinghouse for Educational Facilities (NCEF). The NCEF is an information resource for people who plan, design, build, operate, and maintain K-12 schools. NCEF is funded by the US Department of Education and is an affiliated Clearinghouse of the National Library of Education's Educational Resource Information Center (ERIC). The National Institute of Building Sciences (NIBS) manages the NCEF.

- The Council of Educational Facility Planners, International (CEFPI). CEFPI serves individuals and firms who are responsible for planning, designing, creating, maintaining, and equipping educational facilities. CEFPI sponsors an exchange of information, professional experiences, best practices research results, and other investigative techniques concerning educational facility planning.

- School Planning \& Management Magazine is written and edited to meet the business and information needs of the district-level buying team, including school board presidents, superintendents, business officials, facility planners, technology directors, and other school administrators working in public school systems serving K-12. The focus of the magazine is on solutions to management and operational problems in such areas as construction, facilities, technology, and purchasing.

\footnotetext{
${ }^{25}$ American School \& University. 1996. 1996 AS\&U Maintenance \& Operations Cost Study. Overland Park, KS: American School \& University.

${ }^{26}$ Lufkin, Peter S., and Anthony J.Pepitone. 1996. The Whitestone Building Maintenance and Repair Cost Reference 1996. Seattle, WA: Whitestone Research.
} 


\subsection{Baseline Measures for Educational Facilities}

The OM\&E baseline measures presented in this section are drawn from several key documents. To promote a better understanding of the terms employed in this section, a comprehensive list of $\mathrm{OM} \& \mathrm{E}$ cost components are identified and defined. These components include the following:

- administration - includes all administrative costs for the facility including payroll costs, equipment, supplies, communications, computer rental, accounting costs, and training costs

- work control - includes all costs necessary for the proper planning, scheduling, and dispatching of maintenance work, including payroll, database maintenance, supervision, and cost estimation

- engineering/architecture - includes all design and engineering costs

- project management - includes all costs associated with actual estimating, contracting, inspecting, and final approval of new or renovated construction

- building maintenance - includes in-house and contracted services for routine repairs, minor corrective maintenance, preventive maintenance and service calls for HVAC, plumbing, electrical, painting, glazing, and elevators

- custodial maintenance - includes interior and exterior functions such as window and building cleaning, snow removal, and operating costs such as towels

- grounds maintenance - includes landscaping and grounds maintenance costs for parking areas, irrigation systems, and fencing

- utilities operations - includes all costs for heating, cooling, lighting, and other utilities for physical plant operations, excluding cost of fuel and purchased utilities

- solid waste disposal - includes all costs associated with refuse removal

- hazardous waste disposal - includes all costs associated with hazardous waste removal

- $\quad$ security - includes all security expenses such as traffic, parking, and building security

\subsubsection{Baseline Measures for K-12 Facilities}

Data from the 1996 AS\&U Maintenance \& Operations Cost Study and the Whitestone Building Maintenance and Repair Cost Reference 1996 are used to develop baseline measures for OM\&E costs for K-12 facilities. Both sets of information are needed because the AS\&U data do not include estimates for major repairs and replacements. Although the Whitestone data include estimates of both maintenance and repair costs, the Whitestone maintenance cost data are aggregated totals and hence provide less detail than the AS\&U maintenance cost data. All data presented in this subsection are recorded in 1996 dollars.

Table 4-1 presents selected median operation, maintenance, and energy cost data for K12 facilities. These data are grouped into four major categories. These categories are: (1) in-house labor; (2) outside labor contract; (3) energy and water/sewer; and (4) supplies. The last row of the table records the total median OM\&E costs for K-12 facilities. 
Reference to Table 4-1 reveals that more than half of the OM\&E cost total is for in-house labor. The next largest cost category is for energy and water (i.e., fuel, electricity, and water/sewer). Supplies and outside labor contract services account for the remainder.

Table 4-1. Annual Operations, Maintenance, and Energy Costs for K-12 Facilities

\begin{tabular}{|l|c|c|}
\hline \multirow{2}{*}{ Cost Category } & \multicolumn{2}{|c|}{ K-12 Facilities } \\
\cline { 2 - 3 } & Dollars per Square Foot & Dollars per Square Meter \\
\hline Payroll (\$) & & $\$ 1.22$ \\
\hline Custodial & $\$ 0.48$ & $\$ 5.17$ \\
\hline Maintenance & $\$ 0.17$ & $\$ 1.83$ \\
\hline Grounds & $\$ 0.20$ & $\$ 2.15$ \\
\hline Outside Labor Contract & $\$ 0.25$ & $\$ 2.69$ \\
\hline Fuel & $\$ 0.56$ & $\$ 6.03$ \\
\hline Electricity & $\$ 0.17$ & $\$ 1.83$ \\
\hline Water/Sewer & $\$ 0.23$ & $\$ 2.48$ \\
\hline Equipment \& Maintenance Supplies & $\$ 0.05$ & $\$ 0.54$ \\
\hline Grounds Equipment \& Supplies & $\mathbf{\$ 3 . 3 2}$ & $\$ \mathbf{3 5 . 7 4}$ \\
\hline Total OM\&E Costs & & \\
\hline
\end{tabular}

The distribution of major repair costs is recorded in Figure 4-1. This distribution is based on data published by Whitestone Research. The data are classified into major cost categories according to ASTM's Standard Classification for Building Elements and Related Sitework-UNIFORMAT II. ${ }^{27}$ The repair cost data are based on a 47,000 $\mathrm{ft}^{2}$ elementary school. The total (undiscounted) major repair cost per gross $\mathrm{ft}^{2}$ over the 50 year period used by Whitestone Research for this facility is $\$ 69.00$.

Figure 4-1 reveals that more than one third of major repair costs are associated with interior finishes. Only three other systems exceed ten percent of the total major repair cost per gross $\mathrm{ft}^{2}$ over the 50-year period. These systems are: (1) HVAC; (2) Electrical; and (3) Plumbing.

Table 4-2 records the most costly major repair tasks. These tasks are ranked in descending order. Associated with each task is a task cost in dollars per $\mathrm{ft}^{2}$ and a percent, expressed as a percent of the total maintenance and repair cost per gross $\mathrm{ft}^{2}$ over the 50 year analysis period. Notice that the most costly major repair tasks are due to the replacement of fluorescent lighting fixtures $\$ 90.31 / \mathrm{m}^{2}\left(\$ 8.39 / \mathrm{ft}^{2}\right)$, the refinishing of plaster wall finishes $\$ 86.97 / \mathrm{m}^{2}\left(\$ 8.08 / \mathrm{ft}^{2}\right)$, the replacement of quarry tile floors $\$ 81.27 / \mathrm{m}^{2}\left(\$ 7.55 / \mathrm{ft}^{2}\right)$, and the refinishing of plaster ceilings $\$ 67.28 / \mathrm{m}^{2}\left(\$ 6.25 / \mathrm{ft}^{2}\right)$.

\footnotetext{
${ }^{27}$ American Society for Testing and Materials. 1998. Standard Classification for Building Elements and Related Sitework-UNIFORMAT II. E-1557. West Conshohocken, PA: American Society for Testing and Materials.
} 
Figure 4-1. Distribution of Major Repair Costs by Building Element Over a 50Year Period

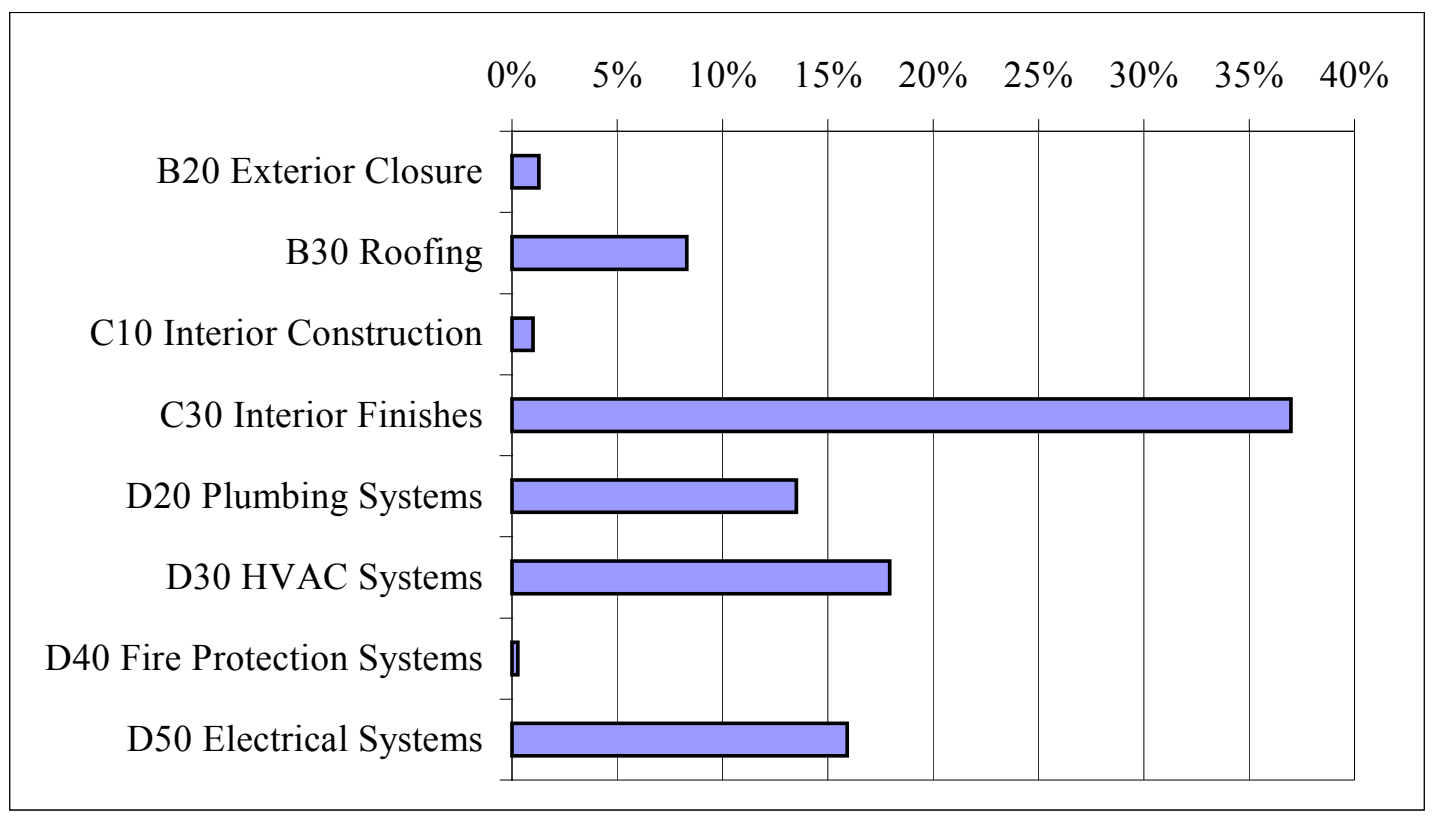

\subsubsection{Baseline Measures for College and University Facilities}

Data from the 1996 AS\&U Maintenance \& Operations Cost Study are used to produce a set of "summary" measures. These data are recorded in Table 4-3. Table 4-3 presents selected median $O M \& E$ cost data for college and university facilities. These data are grouped into four major categories. These categories are: (1) labor; (2) energy and water/sewer; (3) supplies; and (4) equipment. The last row of the table records the total $\mathrm{OM} \& \mathrm{E}$ costs for college and university facilities.

Reference to Table 4-3 reveals that more than half of the OM\&E cost total is for labor (i.e., salaries plus fringe). The next largest cost category is for energy and water. Supplies and equipment maintenance/purchases account for the remainder.

Data from the Association of Higher Education Facilities Officers (APPA) are used to establish detailed OM\&E baseline measures for college and university facilities. These data were collected in 1995 for the 1993-94 fiscal year. It should be noted that data presented here represent only the most general of the data available in the APPA Comparative Costs and Staffing Report for Colleges and University Facilities. 
Table 4-2. Most Costly Major Repair Tasks Over a 50 Year Period

\begin{tabular}{|c|c|c|c|}
\hline \multirow[b]{2}{*}{ Major Repair Task } & \multicolumn{2}{|c|}{ Task Cost $^{1}$} & \multirow[b]{2}{*}{ Percent $^{2}$} \\
\hline & $\begin{array}{c}\text { Dollars } \\
\text { per } \\
\text { Square } \\
\text { Foot } \\
\end{array}$ & $\begin{array}{c}\text { Dollars } \\
\text { per } \\
\text { Square } \\
\text { Meter }\end{array}$ & \\
\hline Replace Fluorescent Lighting Fixture, $160 \mathrm{~W}$ & $\$ 8.39$ & $\$ 90.31$ & $6.0 \%$ \\
\hline Refinish Plaster Wall Finish & $\$ 8.08$ & $\$ 86.97$ & $5.7 \%$ \\
\hline Replace Quarry Tile Floor & $\$ 7.55$ & $\$ 81.27$ & $5.4 \%$ \\
\hline Refinish Plaster Ceiling & $\$ 6.25$ & $\$ 67.27$ & $4.4 \%$ \\
\hline Replace Pipe \& Fittings, 2" Copper, Cold Water & $\$ 4.09$ & $\$ 44.02$ & $2.9 \%$ \\
\hline Place New Membrane Over Existing Built-up Roof & $\$ 3.45$ & $\$ 37.14$ & $2.5 \%$ \\
\hline Replace Vinyl Tile Flooring & $\$ 3.40$ & $\$ 36.60$ & $2.4 \%$ \\
\hline Replace Chiller, Reciprocal Water-Cooled Hermetic, 165 Tons & $\$ 3.40$ & $\$ 36.60$ & $2.4 \%$ \\
\hline Replace Air Handler, Multizone, 50,000 Cfm & $\$ 2.64$ & $\$ 28.42$ & $1.9 \%$ \\
\hline Membrane Removal \& Replacement, Built-up Roof & $\$ 2.54$ & $\$ 27.34$ & $1.8 \%$ \\
\hline Replace Pipe \& Fitting 3/4" Copper, Cold Water & $\$ 2.40$ & $\$ 25.83$ & $1.7 \%$ \\
\hline Repair Chiller, Reciprocal Water-Cooled Hermetic, 165 Tons & $\$ 1.96$ & $\$ 21.10$ & $1.4 \%$ \\
\hline Replace Cooling Tower, 200 Ton & $\$ 1.50$ & $\$ 16.15$ & $1.1 \%$ \\
\hline Replace Air Handler, Multizone, 15,000 Cfm & $\$ 1.42$ & $\$ 15.28$ & $1.0 \%$ \\
\hline Refinish Concrete Exterior Wall 1st Floor & $\$ 0.89$ & $\$ 9.58$ & $0.6 \%$ \\
\hline Replace Carpet, Nylon 20 oz., Low Traffic & $\$ 0.81$ & $\$ 8.72$ & $0.6 \%$ \\
\hline Replace Pipe Insulation, Cold Water & $\$ 0.77$ & $\$ 8.29$ & $0.5 \%$ \\
\hline Replace Smoke Detector & $\$ 0.75$ & $\$ 8.07$ & $0.5 \%$ \\
\hline Replace Transformer, Dry, less than $15,000 \mathrm{~V}$ & $\$ 0.72$ & $\$ 7.75$ & $0.5 \%$ \\
\hline Replace Pipe \& Fittings, 3/4" Copper, Hot Water & $\$ 0.67$ & $\$ 7.21$ & $0.5 \%$ \\
\hline Replace Circulation Pump 5 Hp, Chiller \& Condenser Water & $\$ 0.65$ & $\$ 7.00$ & $0.5 \%$ \\
\hline Replace Gas Boiler, $2500 \mathrm{Mbh}$ & $\$ 0.61$ & $\$ 6.57$ & $0.4 \%$ \\
\hline Replace Solid Core (w/ Safety Glass) Painted Interior Door & $\$ 0.55$ & $\$ 5.92$ & $0.4 \%$ \\
\hline Refinish Concrete Block (Painted) Wall & $\$ 0.41$ & $\$ 4.41$ & $0.3 \%$ \\
\hline Replace Motor Starter, 21-50 Hp, $<600 \mathrm{~V}$ & $\$ 0.36$ & $\$ 3.88$ & $0.3 \%$ \\
\hline Replace Water Heater, Gas/Oil 130 Gph & $\$ 0.31$ & $\$ 3.34$ & $0.2 \%$ \\
\hline Replace Receptacle and Plug & $\$ 0.29$ & $\$ 3.12$ & $0.2 \%$ \\
\hline Repair Cooling Tower, 200 Ton & $\$ 0.28$ & $\$ 3.01$ & $0.2 \%$ \\
\hline Replace Pipe Insulation, Hot Water & $\$ 0.26$ & $\$ 2.80$ & $0.2 \%$ \\
\hline Replace Tankless Water Closet & $\$ 0.22$ & $\$ 2.37$ & $0.2 \%$ \\
\hline
\end{tabular}


Table 4-3. Annual Operations, Maintenance, and Energy Costs for College and University Facilities

\begin{tabular}{|l|c|c|}
\hline \multirow{2}{*}{ Cost Category } & \multicolumn{2}{|c|}{ All Colleges and Universities } \\
\cline { 2 - 3 } & Dollars per Square Foot & Dollars per Square Meter \\
\hline Salaries & $\$ 1.42$ & $\$ 15.28$ \\
\hline Benefits & $\$ 0.40$ & $\$ 4.31$ \\
\hline Energy & $\$ 1.07$ & $\$ 11.52$ \\
\hline Water/Sewer & $\$ 0.11$ & $\$ 1.18$ \\
\hline Supplies & $\$ 0.29$ & $\$ 3.12$ \\
\hline Equipment Maintenance & $\$ 0.11$ & $\$ 1.18$ \\
\hline Equipment Purchases & $\$ 0.11$ & $\$ 1.18$ \\
\hline Total OM\&E Costs & $\mathbf{\$ 3 . 5 1}$ & $\mathbf{\$ 3 7 . 7 8}$ \\
\hline
\end{tabular}

Table 4-4 Part A and Part B presents selected aggregated mean operations, maintenance, and energy cost data for college and university facilities grouped by funding source, region, and by number of Full-Time Equivalent (FTE) enrollment students at the facility.

Figures 4-2 through 4-5 show selected mean operations costs in dollars per gross $\mathrm{m}^{2}\left(\mathrm{ft}^{2}\right)$. Figure 4-2 compares selected operations costs for all college and university facilities combined. The figure shows that building maintenance, custodial maintenance (cleaning), and utility operations (which exclude the cost of fuels) are the largest cost components, in addition to fuel costs.

Figure 4-3 compares building and custodial maintenance costs for colleges and facilities by the size of the establishment (as measured by the number of FTE students). Reference to the figure indicates that there is no apparent downward trend in unit costs for larger facilities as might be expected. Figure 4-4, which is based upon data presented in Table 4-5 Part A and Part B, shows electricity costs for educational facilities by funding source. The figure indicates that private institutions have approximately $10 \%$ lower electricity costs per unit area compared with publicly funded facilities. Reference to Table 4-5 also indicates that there are significant regional differences in total electricity costs in the US. The mean electricity cost for all facilities combined is $\$ 10.75 /$ gross $\mathrm{m}^{2}\left(\$ 0.99 /\right.$ gross $\left.\mathrm{ft}^{2}\right)$.

Figure 4-5, which is based upon data presented in Table 4-6 Part A and Part B, shows gas consumption by funding source for all educational facilities. Reference to the figure indicates that privately funded facilities have higher consumption costs than publicly funded sources. Comparison of Figure 4-4 and Figure 4-5 shows that private and publicly funded facilities have comparable energy costs per unit area when electricity and gas costs are combined. 
Table 4-4. Selected Annual Operations Costs for College and University Facilities by Funding Source, Region, and Number of Students

Part A: Dollars per Square Foot

\begin{tabular}{|c|c|c|c|c|c|c|c|c|c|c|c|}
\hline $\begin{array}{c}\text { Carnegie } \\
\text { Classification }\end{array}$ & $\begin{array}{l}\text { Administrative } \\
\text { Costs }\end{array}$ & $\begin{array}{c}\text { Work } \\
\text { Control }\end{array}$ & $\begin{array}{c}\text { Engineering \& } \\
\text { Architecture }\end{array}$ & $\begin{array}{c}\text { Project } \\
\text { Manage- } \\
\text { ment }\end{array}$ & $\begin{array}{c}\text { Building } \\
\text { Mainten- } \\
\text { ance }\end{array}$ & $\begin{array}{c}\text { Custodial } \\
\text { Mainten- } \\
\text { ance }\end{array}$ & $\begin{array}{c}\text { Grounds } \\
\text { Mainten- } \\
\text { ance }\end{array}$ & $\begin{array}{c}\text { Utilities } \\
\text { Opera- } \\
\text { tions }\end{array}$ & $\begin{array}{c}\text { Solid } \\
\text { Waste } \\
\text { Disposal }\end{array}$ & $\begin{array}{c}\text { Hazardous } \\
\text { Waste } \\
\text { Disposal }\end{array}$ & Security \\
\hline \multicolumn{12}{|l|}{$\begin{array}{l}\text { Funding } \\
\text { Source }\end{array}$} \\
\hline $\begin{array}{l}\text { Private } \\
\text { Institutions }\end{array}$ & 0.258 & 0.087 & 0.106 & 0.104 & 0.989 & 0.846 & 0.280 & 0.698 & 0.066 & 0.048 & 0.355 \\
\hline $\begin{array}{l}\text { Public } \\
\text { Institutions }\end{array}$ & 0.264 & 0.076 & 0.114 & 0.114 & 0.851 & 0.942 & 0.273 & 0.554 & 0.046 & 0.032 & 0.353 \\
\hline All Institutions & 0.262 & 0.079 & 0.112 & 0.112 & 0.895 & 0.912 & 0.275 & 0.594 & 0.052 & 0.037 & 0.354 \\
\hline \multicolumn{12}{|l|}{ Region } \\
\hline Eastern & 0.314 & 0.089 & 0.158 & 0.170 & 0.988 & 1.022 & 0.260 & 0.635 & 0.079 & 0.031 & 0.487 \\
\hline Southeastern & 0.240 & 0.071 & 0.087 & 0.106 & 0.953 & 0.846 & 0.303 & 0.548 & 0.054 & 0.030 & 0.406 \\
\hline Midwest & 0.238 & 0.079 & 0.092 & 0.058 & 0.825 & 1.003 & 0.244 & 0.678 & 0.037 & 0.029 & 0.291 \\
\hline Central & 0.202 & 0.062 & 0.080 & 0.053 & 0.695 & 0.716 & 0.207 & 0.536 & 0.027 & 0.032 & 0.246 \\
\hline $\begin{array}{l}\text { Rocky } \\
\text { Mountain }\end{array}$ & 0.208 & 0.082 & 0.090 & 0.101 & 0.810 & 0.807 & 0.264 & 0.597 & 0.032 & 0.021 & 0.209 \\
\hline Pacific Coast & 0.367 & 0.084 & 0.138 & 0.130 & 1.117 & 1.013 & 0.440 & 0.509 & 0.060 & 0.075 & 0.351 \\
\hline \multicolumn{12}{|l|}{$\begin{array}{c}\begin{array}{c}\text { Number of } \\
\text { Students }\end{array} \\
\end{array}$} \\
\hline $0-1,999$ & 0.278 & 0.100 & 0.095 & 0.128 & 0.946 & 0.817 & 0.268 & 0.753 & 0.060 & 0.048 & 0.271 \\
\hline $2,000-4,999$ & 0.289 & 0.090 & 0.120 & 0.155 & 0.912 & 0.966 & 0.300 & 0.666 & 0.058 & 0.025 & 0.374 \\
\hline $5,000-11,999$ & 0.234 & 0.075 & 0.151 & 0.139 & 0.846 & 0.991 & 0.284 & 0.425 & 0.051 & 0.038 & 0.430 \\
\hline $12,000-19,999$ & 0.300 & 0.055 & 0.081 & 0.065 & 0.897 & 0.907 & 0.253 & 0.897 & 0.907 & 0.253 & 0.564 \\
\hline $20,000+$ & 0.162 & 0.063 & 0.081 & 0.055 & 0.831 & 0.915 & 0.218 & 0.606 & 0.041 & 0.031 & 0.343 \\
\hline
\end{tabular}

Part B: Dollars per Square Meter

\begin{tabular}{|c|c|c|c|c|c|c|c|c|c|c|c|}
\hline $\begin{array}{c}\text { Carnegie } \\
\text { Classification }\end{array}$ & $\begin{array}{l}\text { Administrative } \\
\text { Costs }\end{array}$ & $\begin{array}{c}\text { Work } \\
\text { Control }\end{array}$ & $\begin{array}{l}\text { Engineering \& } \\
\text { Architecture }\end{array}$ & $\begin{array}{c}\text { Project } \\
\text { Manage- } \\
\text { ment }\end{array}$ & $\begin{array}{c}\text { Building } \\
\text { Mainten- } \\
\text { ance }\end{array}$ & $\begin{array}{c}\text { Custodial } \\
\text { Mainten- } \\
\text { ance }\end{array}$ & $\begin{array}{c}\text { Grounds } \\
\text { Mainten- } \\
\text { ance }\end{array}$ & $\begin{array}{c}\text { Utilities } \\
\text { Opera- } \\
\text { tions }\end{array}$ & $\begin{array}{c}\text { Solid } \\
\text { Waste } \\
\text { Disposal }\end{array}$ & $\begin{array}{c}\text { Hazardous } \\
\text { Waste } \\
\text { Disposal }\end{array}$ & Security \\
\hline \multicolumn{12}{|l|}{$\begin{array}{c}\text { Funding } \\
\text { Source } \\
\end{array}$} \\
\hline \begin{tabular}{|l} 
Private \\
Institutions
\end{tabular} & 2.776 & 0.936 & 1.141 & 1.119 & 10.642 & 9.103 & 3.013 & 7.510 & 0.710 & 0.516 & 3.820 \\
\hline $\begin{array}{l}\text { Public } \\
\text { Institutions }\end{array}$ & 2.841 & 0.818 & 1.227 & 1.227 & 9.157 & 10.136 & 2.937 & 5.961 & 0.495 & 0.344 & 3.798 \\
\hline All Institutions & 2.819 & 0.850 & 1.205 & 1.205 & 9.630 & 9.813 & 2.959 & 6.391 & 0.560 & 0.398 & 3.809 \\
\hline \multicolumn{12}{|l|}{ Region } \\
\hline \begin{tabular}{|l|} 
Eastern \\
\end{tabular} & 3.379 & 0.958 & 1.700 & 1.829 & 10.631 & 10.997 & 2.798 & 6.833 & 0.850 & 0.334 & 5.240 \\
\hline \begin{tabular}{|l|} 
Southeastern \\
\end{tabular} & 2.582 & 0.764 & 0.936 & 1.141 & 10.254 & 9.103 & 3.260 & 5.896 & 0.581 & 0.323 & 4.369 \\
\hline \begin{tabular}{|l|} 
Midwest \\
\end{tabular} & 2.561 & 0.850 & 0.990 & 0.624 & 8.877 & 10.792 & 2.625 & 7.295 & 0.398 & 0.312 & 3.131 \\
\hline Central & 2.174 & 0.667 & 0.861 & 0.570 & 7.478 & 7.704 & 2.227 & 5.767 & 0.291 & 0.344 & 2.647 \\
\hline $\begin{array}{l}\text { Rocky } \\
\text { Mountain }\end{array}$ & 2.238 & 0.882 & 0.968 & 1.087 & 8.716 & 8.683 & 2.841 & 6.424 & 0.344 & 0.226 & 2.249 \\
\hline \begin{tabular}{|l|} 
Pacific Coast \\
\end{tabular} & 3.949 & 0.904 & 1.485 & 1.399 & 12.019 & 10.900 & 4.734 & 5.477 & 0.646 & 0.807 & 3.777 \\
\hline \multicolumn{12}{|l|}{$\begin{array}{c}\text { Number of } \\
\text { Students } \\
\end{array}$} \\
\hline $0-1,999$ & 2.991 & 1.076 & 1.022 & 1.377 & 10.179 & 8.791 & 2.884 & 8.102 & 0.646 & 0.516 & 2.916 \\
\hline $2,000-4,999$ & 3.110 & 0.968 & 1.291 & 1.668 & 9.813 & 10.394 & 3.228 & 7.166 & 0.624 & 0.269 & 4.024 \\
\hline $5,000-11,999$ & 2.518 & 0.807 & 1.625 & 1.496 & 9.103 & 10.663 & 3.056 & 4.573 & 0.549 & 0.409 & 4.627 \\
\hline $12,000-19,999$ & 3.228 & 0.592 & 0.872 & 0.699 & 9.652 & 9.759 & 2.722 & 9.652 & 9.759 & 2.722 & 6.069 \\
\hline $20,000+$ & 1.743 & 0.678 & 0.872 & 0.592 & 8.942 & 9.845 & 2.346 & 6.521 & 0.441 & 0.334 & 3.691 \\
\hline
\end{tabular}


Figure 4-2. Selected Annual Operations Costs for College and University Facilities

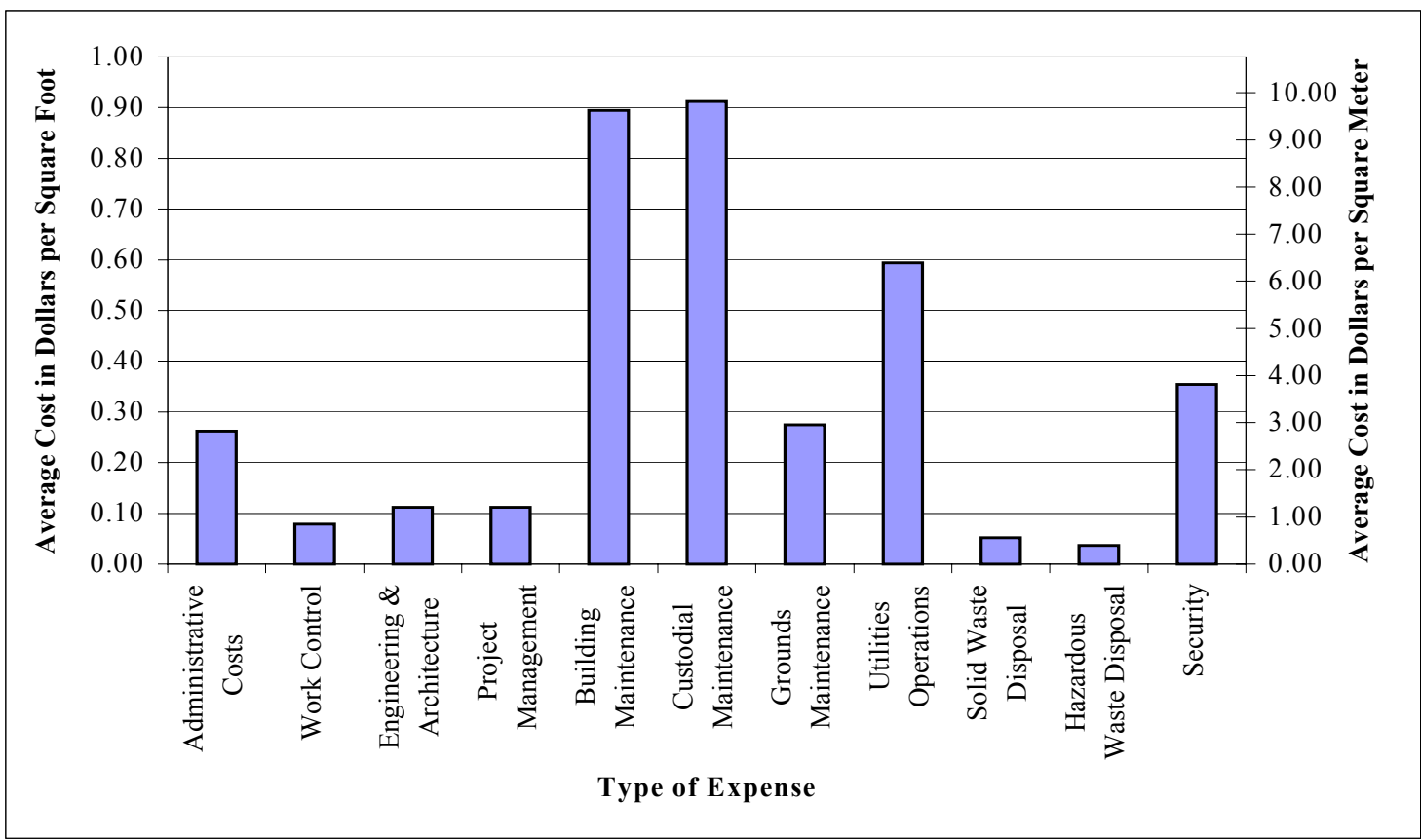

Figure 4-3. Annual Building and Custodial Maintenance Costs for Colleges and Universities by Number of Students

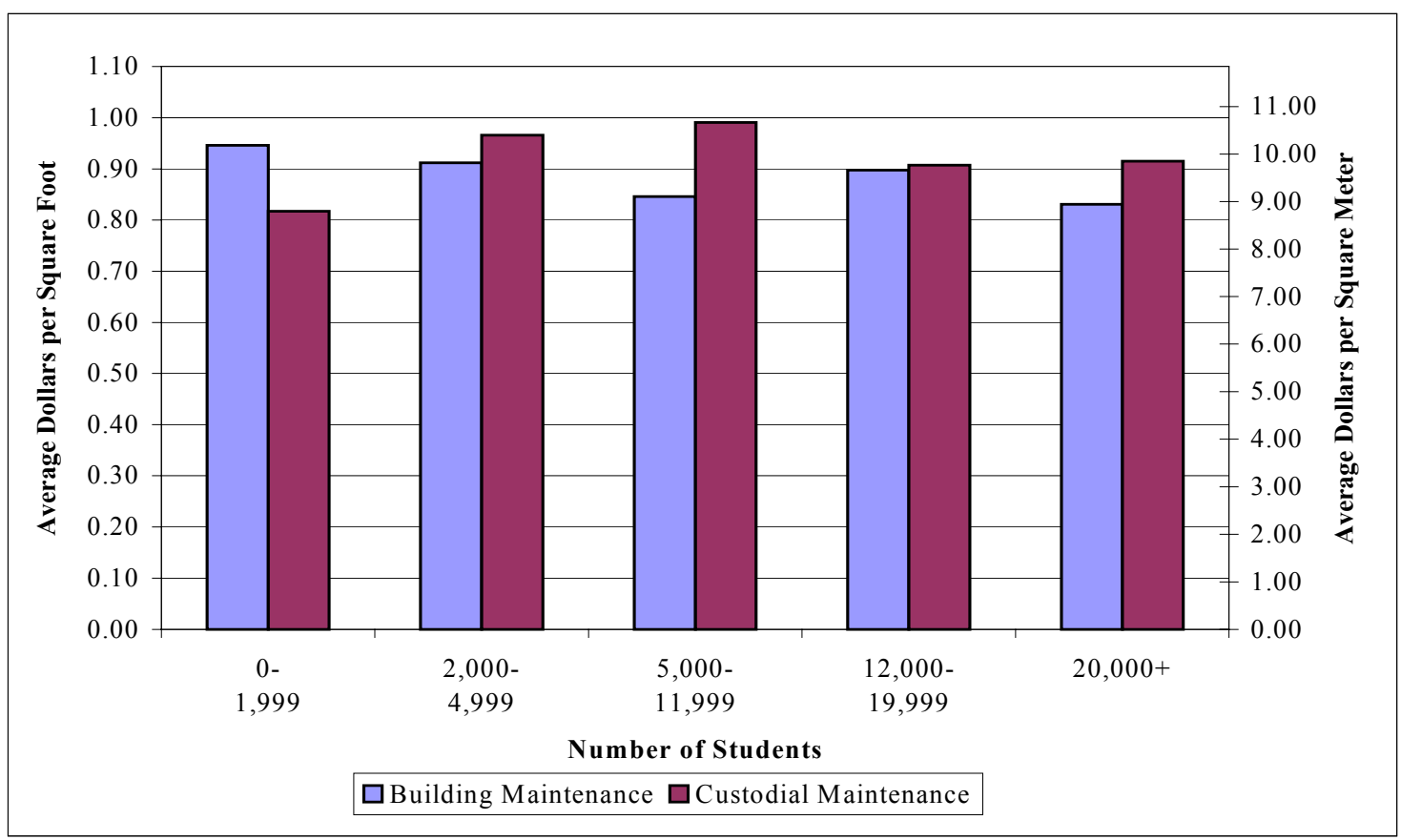


Figure 4-4. Annual Electricity Cost by Funding Source for Colleges and Universities

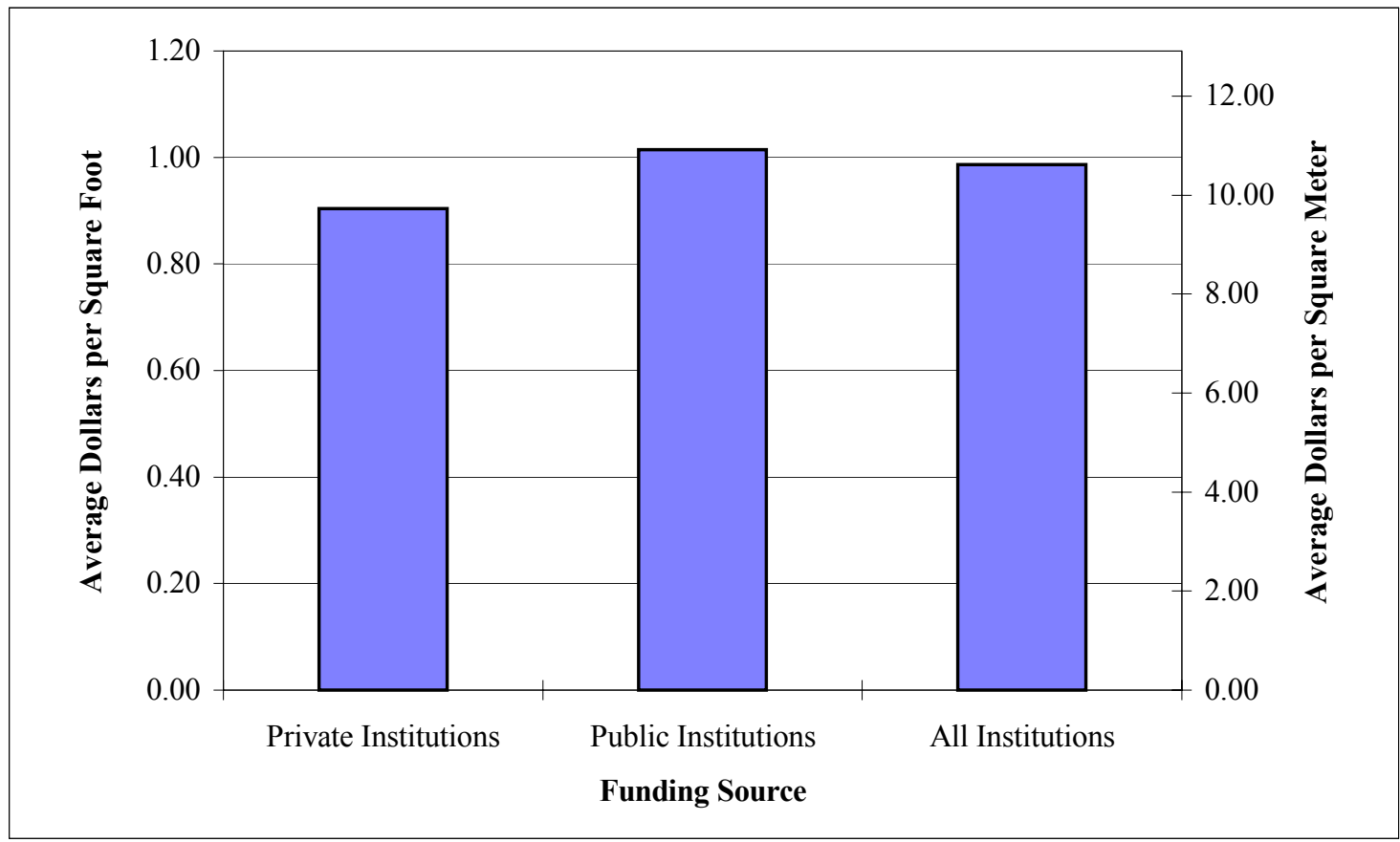

Figure 4-5. Annual Mean Gas Cost by Funding Source for Colleges and Universities

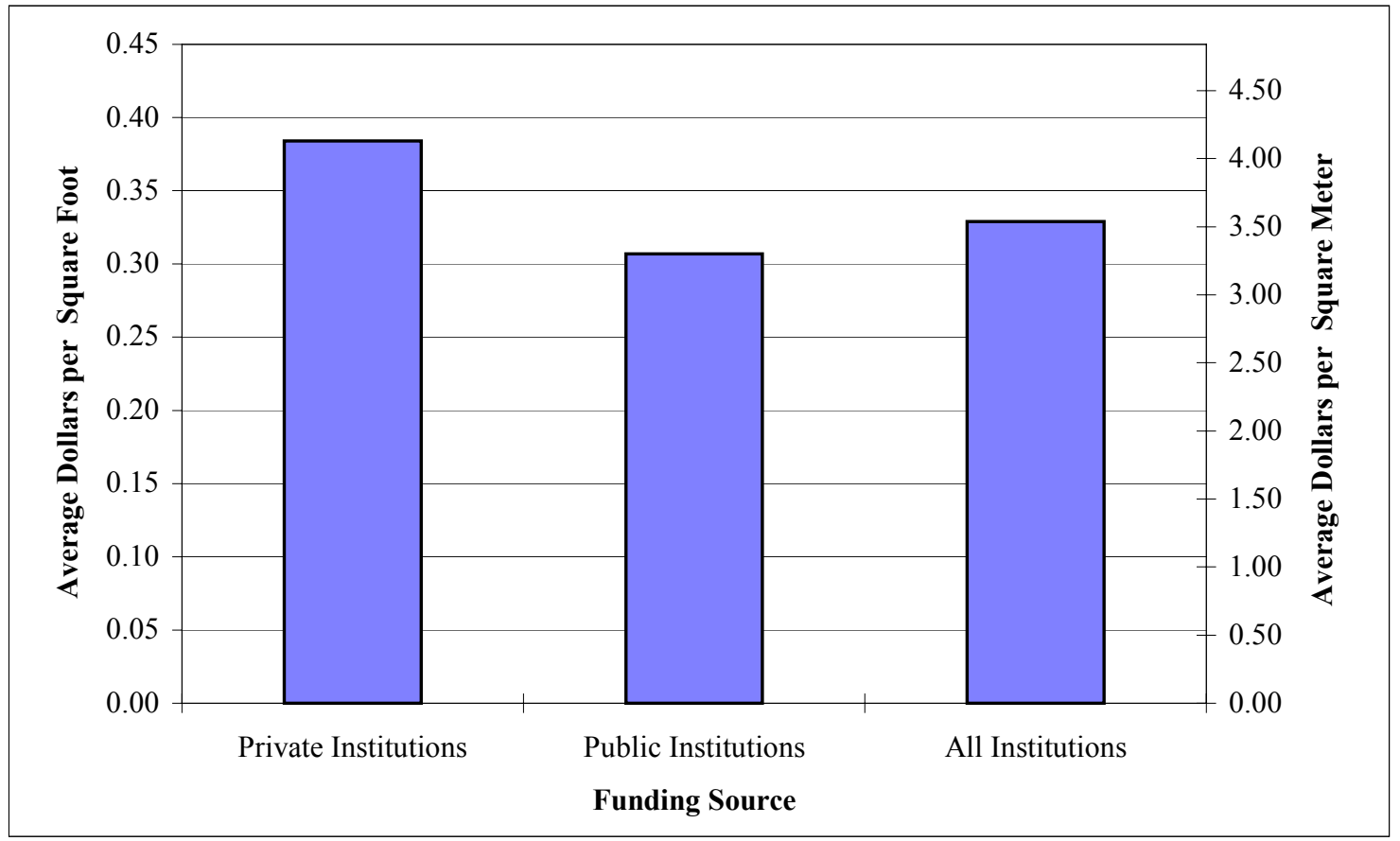


Table 4-5. Annual Mean Electricity Usage for College and University Facilities by Funding Source, Region, and Number of Students

Part A: $\quad$ English Units

\begin{tabular}{|l|c|c|c|c|c|}
\hline $\begin{array}{c}\text { Carnegie } \\
\text { Classification }\end{array}$ & Cost per kwh & $\begin{array}{c}\text { Kwh per } \\
\text { Gross } \\
\text { Building } \\
\text { Square Foot }\end{array}$ & $\begin{array}{c}\text { Cost per } \\
\text { Gross } \\
\text { Building } \\
\text { Square Foot }\end{array}$ & $\begin{array}{c}\text { Kwh per FTE } \\
\text { Student }\end{array}$ & $\begin{array}{c}\text { Cogeneration } \\
\text { Cost per kwh }\end{array}$ \\
\hline Funding Source & & & & & \\
\hline Private Institutions & 0.069 & 13.1 & 0.904 & 6,725 & 0.040 \\
\hline Public Institutions & 0.059 & 17.2 & 1.015 & 4,186 & 0.042 \\
\hline All Institutions & 0.062 & 15.9 & 0.986 & 4,983 & 0.041 \\
\hline \multicolumn{1}{|c|}{ Region } & & & & & \\
\hline Eastern & 0.077 & 14.3 & 1.101 & 4,718 & 0.050 \\
\hline Southeastern & 0.056 & 19.5 & 1.092 & 6,372 & 0.037 \\
\hline Midwest & 0.059 & 16.6 & 0.979 & 5,292 & 0.037 \\
\hline Central & 0.053 & 16.1 & 0.853 & 5,115 & 0.043 \\
\hline Rocky Mountain & 0.053 & 13.0 & 0.689 & 2,839 & 0.040 \\
\hline Pacific Coast & 0.067 & 14.0 & 0.938 & 3,842 & 0.040 \\
\hline \multicolumn{1}{|c|}{ Number of } & & & & & \\
\hline \multicolumn{1}{|c|}{ Students } & & 14.1 & 0.945 & 7,430 & 0.061 \\
\hline 2,999 & 0.067 & 15.2 & 0.942 & 4,612 & 0.045 \\
\hline $5,000-4,999$ & 0.062 & 16.9 & 1.031 & 3,711 & 0.044 \\
\hline $12,000-19,999$ & 0.061 & 16.3 & 1.027 & 3,310 & 0.039 \\
\hline $20,000+$ & 0.063 & 19.5 & 1.034 & 4,547 & 0.032 \\
\hline
\end{tabular}

Part B: $\quad$ SI Units

\begin{tabular}{|l|c|c|c|c|c|}
\hline $\begin{array}{c}\text { Carnegie } \\
\text { Classification }\end{array}$ & Cost per MJ & $\begin{array}{c}\text { MJ per Gross } \\
\text { Building } \\
\text { Square Meter }\end{array}$ & $\begin{array}{c}\text { Cost per } \\
\text { Gross } \\
\text { Building } \\
\text { Square Meter }\end{array}$ & $\begin{array}{c}\text { MJ per FTE } \\
\text { Student }\end{array}$ & $\begin{array}{c}\text { Cogeneration } \\
\text { Cost per MJ }\end{array}$ \\
\hline Funding Source & & & & & \\
\hline Private Institutions & 0.019 & 507.6 & 9.730 & 24,210 & 0.011 \\
\hline Public Institutions & 0.016 & 666.5 & 10.924 & 15,070 & 0.012 \\
\hline All Institutions & 0.017 & 616.1 & 10.612 & 17,939 & 0.011 \\
\hline \multicolumn{1}{|c|}{ Region } & & & & & \\
\hline Eastern & 0.021 & 554.1 & 11.853 & 16,985 & 0.014 \\
\hline Southeastern & 0.016 & 755.6 & 11.755 & 22,939 & 0.010 \\
\hline Midwest & 0.016 & 643.3 & 10.543 & 19,051 & 0.010 \\
\hline Central & 0.015 & 623.9 & 9.186 & 18,414 & 0.012 \\
\hline Rocky Mountain & 0.015 & 503.8 & 7.417 & 10,220 & 0.011 \\
\hline Pacific Coast & 0.019 & 542.5 & 10.097 & 13,831 & 0.011 \\
\hline \multicolumn{1}{|c|}{ Number of } & & & & & \\
\hline \multicolumn{1}{|c|}{ Students } & 0.019 & 546.4 & 10.169 & 26,748 & 0.017 \\
\hline $2,1,999$ & 0.017 & 589.0 & 10.145 & 16,603 & 0.013 \\
\hline $5,000-4,999$ & 0.017 & 654.9 & 11.097 & 13,360 & 0.012 \\
\hline $12,000-19,999$ & 0.018 & 631.6 & 11.054 & 11,916 & 0.011 \\
\hline $20,000+$ & 0.015 & 755.6 & 11.125 & 16,369 & 0.009 \\
\hline
\end{tabular}


Table 4-6. Annual Mean Gas Consumption for College and University Facilities by Funding Source, Region, and Number of Students

Part A: $\quad$ English Units

\begin{tabular}{|c|c|c|c|c|}
\hline $\begin{array}{c}\text { Carnegie } \\
\text { Classification }\end{array}$ & $\begin{array}{c}\text { Cost per 100 } \\
\text { Cubic Feet }\end{array}$ & $\begin{array}{c}\text { Quantity per } \\
\text { Gross Building } \\
\text { Square Foot }\end{array}$ & $\begin{array}{c}\text { Cost per Gross } \\
\text { Building Square } \\
\text { Foot }\end{array}$ & $\begin{array}{c}\text { Quantity per FTE } \\
\text { Student }\end{array}$ \\
\hline Funding Source & & & & \\
\hline Private Institutions & 0.48 & 0.80 & 0.38 & 357.20 \\
\hline Public Institutions & 0.42 & 0.73 & 0.31 & 201.10 \\
\hline All Institutions & 0.44 & 0.75 & 0.33 & 248.30 \\
\hline Region & & & & \\
\hline Eastern & 0.53 & 0.72 & 0.38 & 223.50 \\
\hline Southeastern & 0.51 & 0.62 & 0.31 & 178.00 \\
\hline Midwest & 0.38 & 0.92 & 0.34 & 334.80 \\
\hline Central & 0.35 & 0.73 & 0.26 & 295.80 \\
\hline Rocky Mountain & 0.42 & 0.89 & 0.37 & 206.70 \\
\hline Pacific Coast & 0.43 & 0.64 & 0.27 & 182.00 \\
\hline $\begin{array}{c}\text { Number of } \\
\text { Students }\end{array}$ & & & & \\
\hline $0-1,999$ & 0.47 & 0.86 & 0.40 & 430.10 \\
\hline $2,000-4,999$ & 0.46 & 0.61 & 0.28 & 219.20 \\
\hline $5,000-11,999$ & 0.44 & 0.72 & 0.32 & 146.20 \\
\hline $12,000-19,999$ & 0.42 & 0.67 & 0.28 & 159.50 \\
\hline $20,000+$ & 0.35 & 0.98 & 0.34 & 228.40 \\
\hline
\end{tabular}

Part B: $\quad$ SI Units

\begin{tabular}{|c|c|c|c|c|}
\hline $\begin{array}{c}\text { Carnegie } \\
\text { Classification }\end{array}$ & $\begin{array}{c}\text { Cost per 100 } \\
\text { Cubic Meters }\end{array}$ & $\begin{array}{c}\text { Quantity per } \\
\text { Gross Building } \\
\text { Square Meter }\end{array}$ & $\begin{array}{c}\text { Cost per Gross } \\
\text { Building Square } \\
\text { Meter }\end{array}$ & $\begin{array}{c}\text { Quantity per FTE } \\
\text { Student }\end{array}$ \\
\hline Funding Source & & & & \\
\hline Private Institutions & 16.95 & .24 & 4.13 & 10.11 \\
\hline Public Institutions & 14.83 & .22 & 3.30 & 5.69 \\
\hline All Institutions & 15.54 & .23 & 3.55 & 7.03 \\
\hline Region & & & & 6.33 \\
\hline Eastern & 18.72 & .22 & 4.11 & 5.04 \\
\hline Southeastern & 18.01 & .19 & 3.40 & 9.48 \\
\hline Midwest & 13.42 & .28 & 3.76 & 8.38 \\
\hline Central & 12.36 & .22 & 2.75 & 5.85 \\
\hline Rocky Mountain & 14.83 & .27 & 4.02 & \\
\hline Pacific Coast & 15.19 & .20 & 2.96 & \\
\hline $\begin{array}{c}\text { Number of } \\
\text { Students }\end{array}$ & & & & 12.18 \\
\hline $0-1,999$ & 16.60 & .26 & 4.35 & 6.21 \\
\hline $2,000-4,999$ & 16.24 & .19 & 3.02 & 4.14 \\
\hline $5,000-11,999$ & 15.54 & .22 & 3.41 & 4.52 \\
\hline $12,000-19,999$ & 14.83 & .20 & 3.03 & 6.47 \\
\hline $20,000+$ & 12.36 & .30 & 3.69 & \\
\hline
\end{tabular}




\subsubsection{Energy Conservation in Educational Facilities}

As noted earlier, the DOE Commercial Buildings Energy Consumption Survey (CBECS) is used to establish the sources for two key data items: (1) the national average energy cost per $\mathrm{m}^{2}$ (per $\mathrm{ft}^{2}$ ); and (2) the rates of utilization of energy conserving features and practices. CBECS is a national sample survey that collects energy-related building characteristics and consumption and expenditure data for US commercial buildings.

Figures 4-6 through 4-13 summarize the information on educational facilities extracted from the CBECS microdata files. With the exception of Figure 4-7, which is organized by year of construction, all of the figures record building size on the horizontal axis. The same eight size categories introduced in Chapter 3 are used in each figure. Tic marks on the horizontal axis are used to help separate the size categories. Two different measures are recorded on the vertical axis. For Figure 4-6 the vertical axis records the annual fuel expenditure per unit of floor area. For Figure 4-7 the vertical axis records the annual fuel expenditure by year of construction. For Figures 4-8 through 4-13 the vertical axis records the percent of total floorspace covered by the factors (i.e., end-use equipment and energy conservation features) under analysis. It is important to recognize that portions of a building's floorspace may be covered by more than one factor. Consequently, the sum total across all factors may exceed $100 \%$ of total floorspace.

Figure 4-6 shows how annual energy expenditures per unit of floor area vary by building size. The figure also records the national average energy expenditure per $\mathrm{m}^{2}\left(\right.$ per $\left.\mathrm{ft}^{2}\right)$. Reference to the figure shows that the national average energy expenditure is $\$ 9.90 / \mathrm{m}^{2}$ $\left(\$ 0.92 / \mathrm{ft}^{2}\right)$. Examination of the figure shows considerable variability about the national average across the eight building size categories. With the exception of the two smallest size categories, the figure does not show any trend towards higher or lower energy expenditures per unit of floor area as building size increases.

Figure 4-7 shows how annual energy expenditures per unit of floor area vary by year of construction. The figure also records the national average energy expenditure per $\mathrm{m}^{2}$ (per $\mathrm{ft}^{2}$ ). Examination of the figure shows a slight upward trend in annual energy expenditures per unit of floor area, for facilities constructed prior to 1990.

Figures 4-8 through 4-13 are concerned with end-use equipment and energy conservation features. Energy is used within buildings by end-use equipment. End-use equipment refers to the specific type of equipment that is used to perform a given end use. Types of end-use equipment include heat pumps, furnaces, packaged air-conditioning units, central chillers, fluorescent light fixtures, and compact fluorescent bulbs. Figures 4-8 through 410 record information on end-use equipment. 
Figure 4-6. Sum of Annual Major Fuel Expenditures of Educational Facilities by Building Size Category

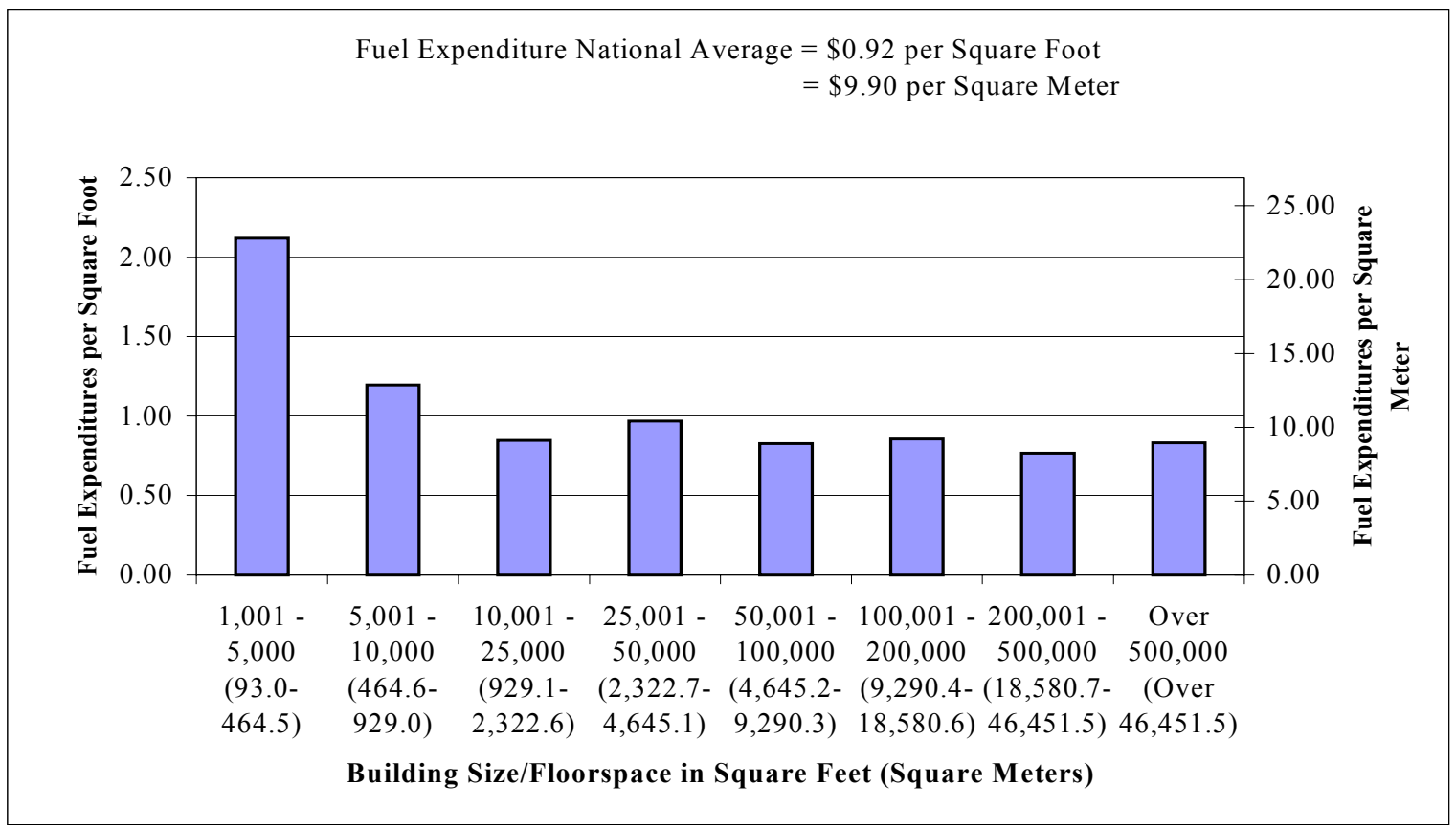

Figure 4-7. Sum of Annual Major Fuel Expenditures of Educational Facilities by Year of Construction

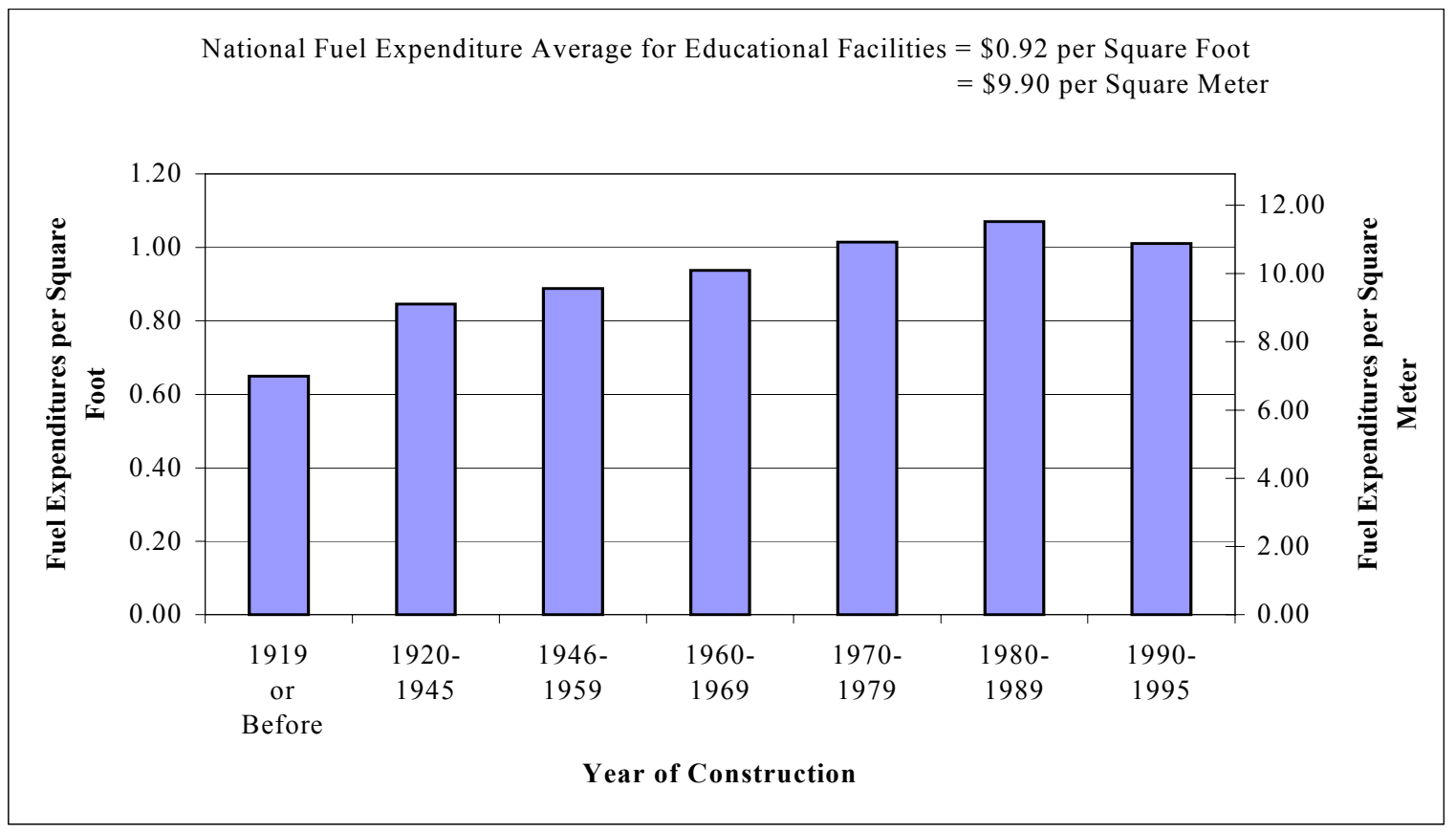


Educational facilities use a variety of features to conserve the use of energy by end-use equipment. Energy conservation features include those related to the building shell, HVAC systems, and lighting systems. Figures 4-11 through 4-13 record information on energy conservation features.

For Figures 4-8 through 4-13 the factors under analysis are listed in a box beneath the legend for the horizontal axis. The number of factors analyzed in each figure range from a high of seven (see Figure 4-8) to a low of four (see Figure 4-12). Each factor is crossreferenced to a bar in the figure. This is done by shading each bar, and for selected bars bolding their border. Each factor is indicated by a small shaded box and a factor name pairing. To identify a specific factor, start at the top and read from left to right across the shaded box/factor name pairings until the factor of interest is found. Note that each factor is recorded for each size category in Figures 4-8 through 4-13. Due to different building characteristics, some factors will have a zero value for some size categories. In such cases, a gap will appear between one or more bars. The positions of each bar, however, will be the same as indicated by the order of the shaded box/factor name pairings. As noted earlier, portions of a building's floorspace may be covered by more than one factor. Consequently, the sum across all factors may exceed $100 \%$ of total floorspace.

Information on space heating equipment for educational facilities is presented in Figure 4-8. Three types of heating equipment were used extensively in educational facilities: packaged heating units, boilers, and district heat. Although all three types were used extensively, their use in educational facilities of different sizes varied considerably. For example, boilers and district heat were used more in larger buildings, while packaged heating units were used more in smaller buildings.

Information on cooling equipment for educational facilities is presented in Figure 4-9. Reference to the figure reveals that packaged air-conditioning units and central chillers were the most widely used type of cooling equipment. However, the two most widely used types of cooling equipment showed significant differences in use by size of building. Packaged air-conditioning units showed relatively greater use in the smallest educational facilities. Central chillers were used primarily in the largest buildings. That equipment type cooled more than $40 \%$ of the combined floorspace of the three largest size categories, but less than $5 \%$ of the combined floorspace of the three smallest size categories.

Information on six types of lighting equipment is summarized in Figure 4-10. The six types of lighting equipment are incandescent, standard fluorescent, compact fluorescent, high-intensity discharge, halogen, and other. Standard fluorescent lighting fixtures were found in nearly all educational facilities (more than $80 \%$ of all floorspace). Incandescent lighting was also widely used (around $60 \%$ of all floorspace). The three newer kinds of lighting technology, high-intensity discharge, compact fluorescent, and halogen, were used primarily in larger educational facilities. 
Figure 4-8. Heating Equipment Usage in Educational Buildings by Building Size Category

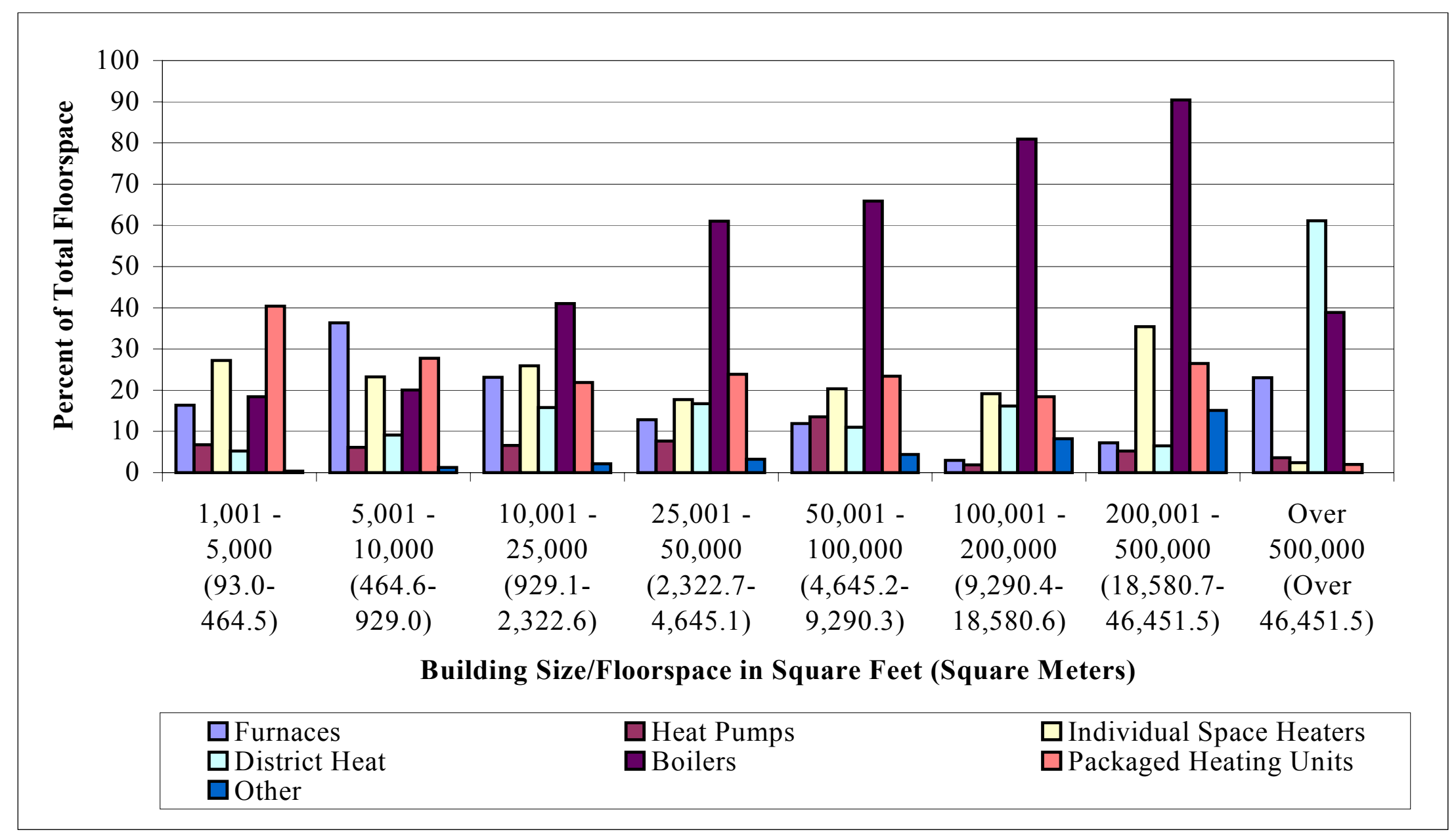


Figure 4-9 Building Cooling Equipment Usage in Educational Buildings by Building Size Category

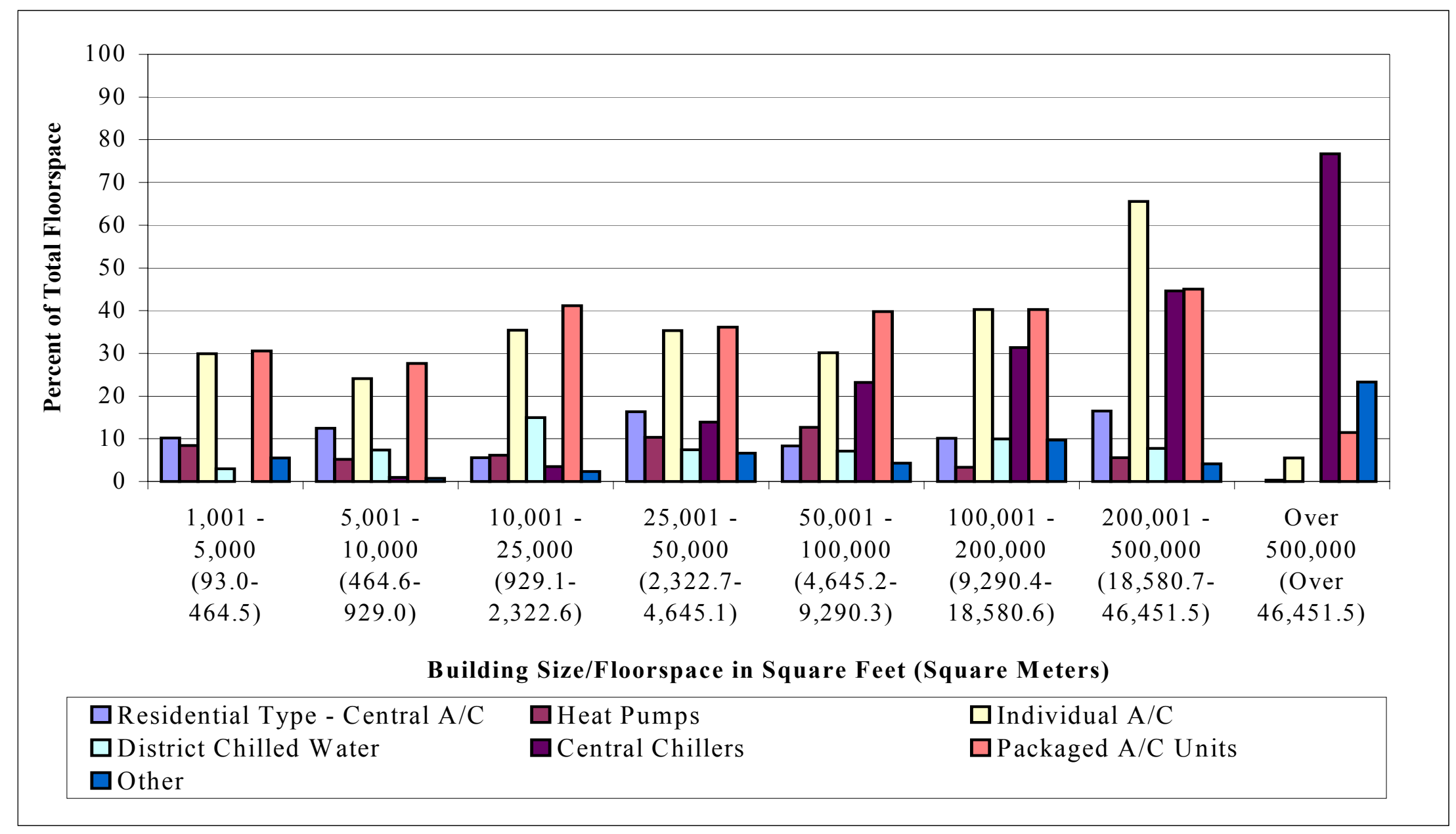


Figure 4-10. Building Lighting Equipment Usage in Educational Buildings by Building Size Category

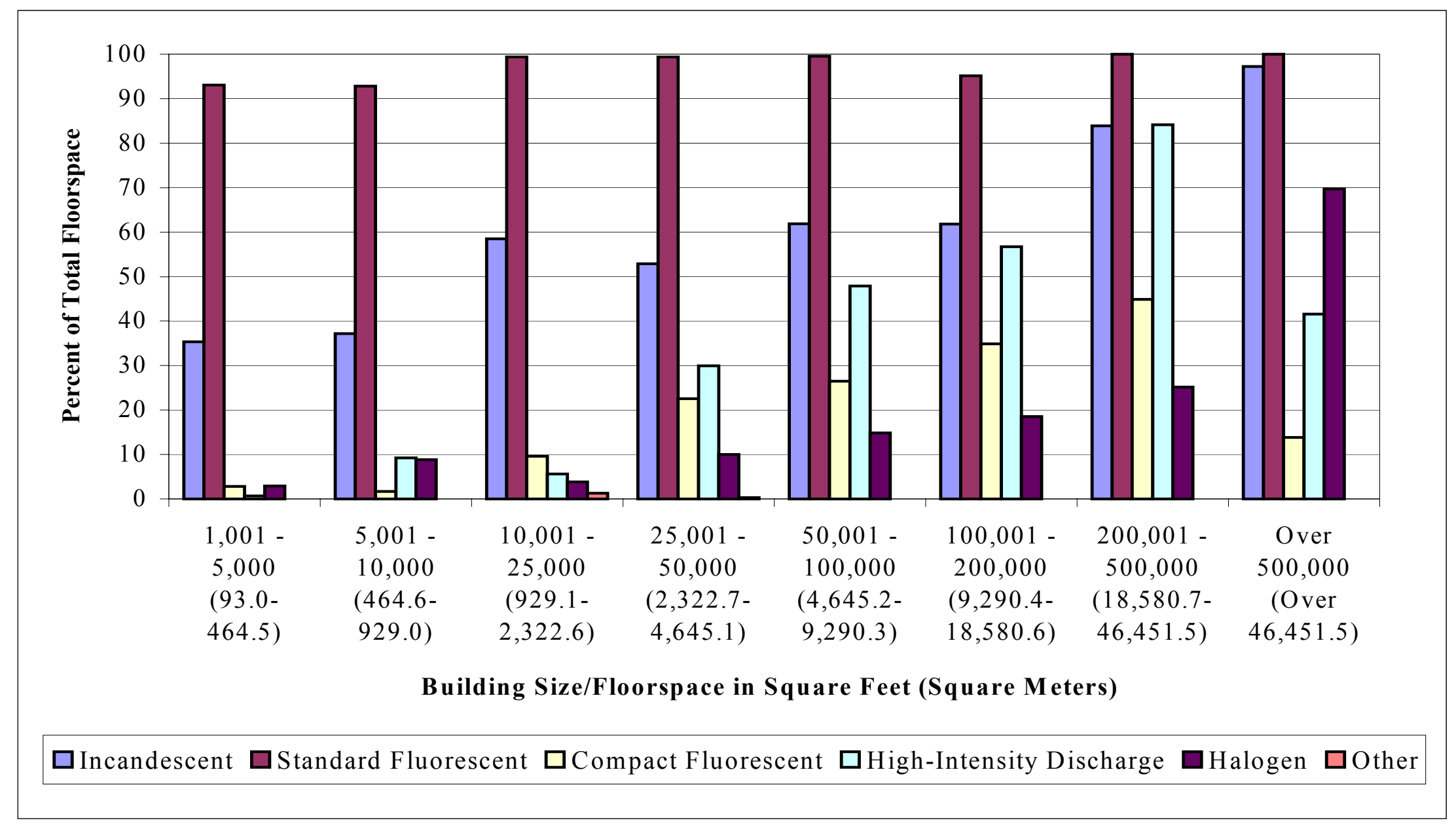


Figure 4-11. Educational Facilities Shell Conservation Features by Building Size Category

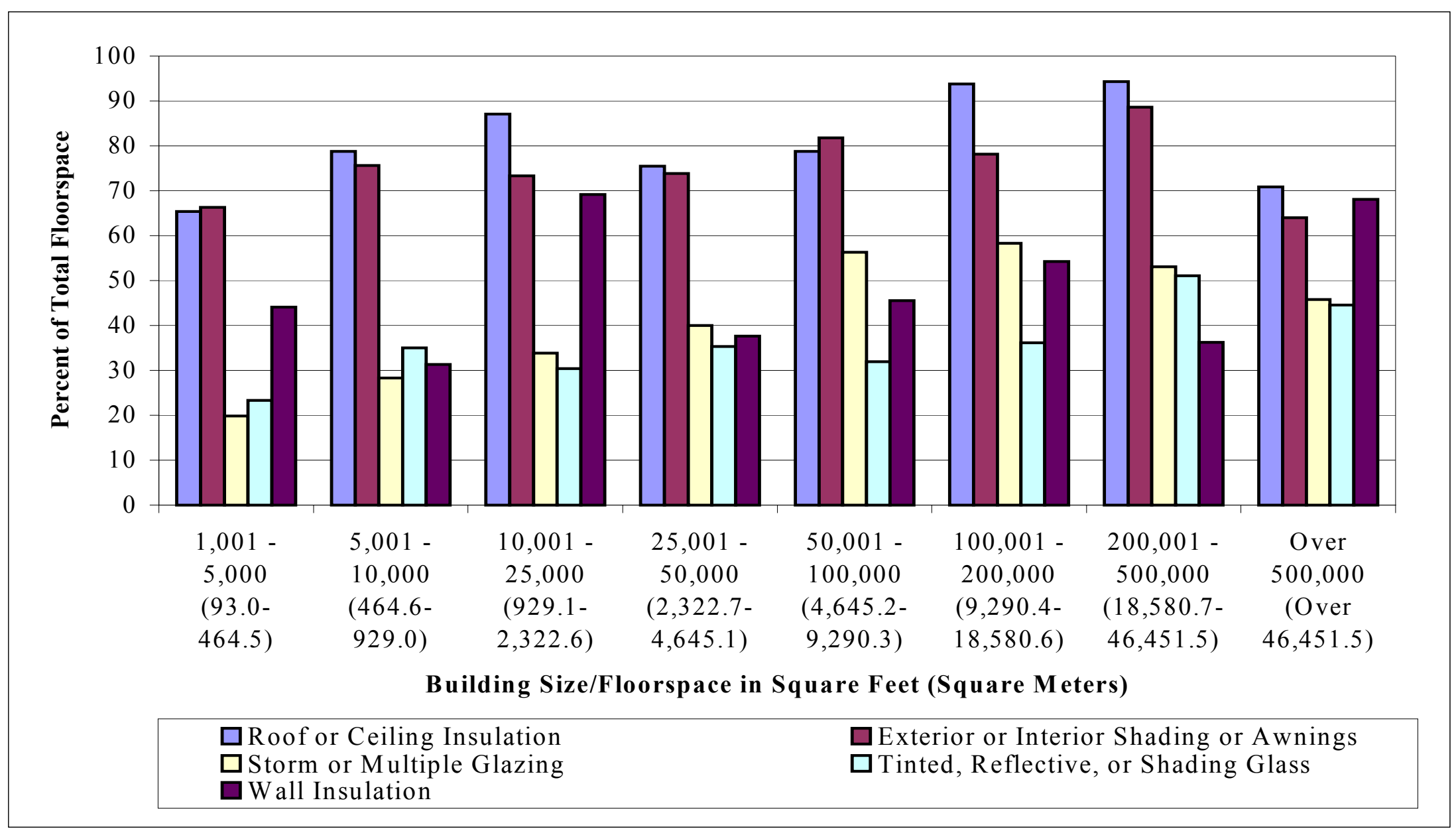


Figure 4-12. Educational Facilities HVAC Conservation Features by Building Size Category

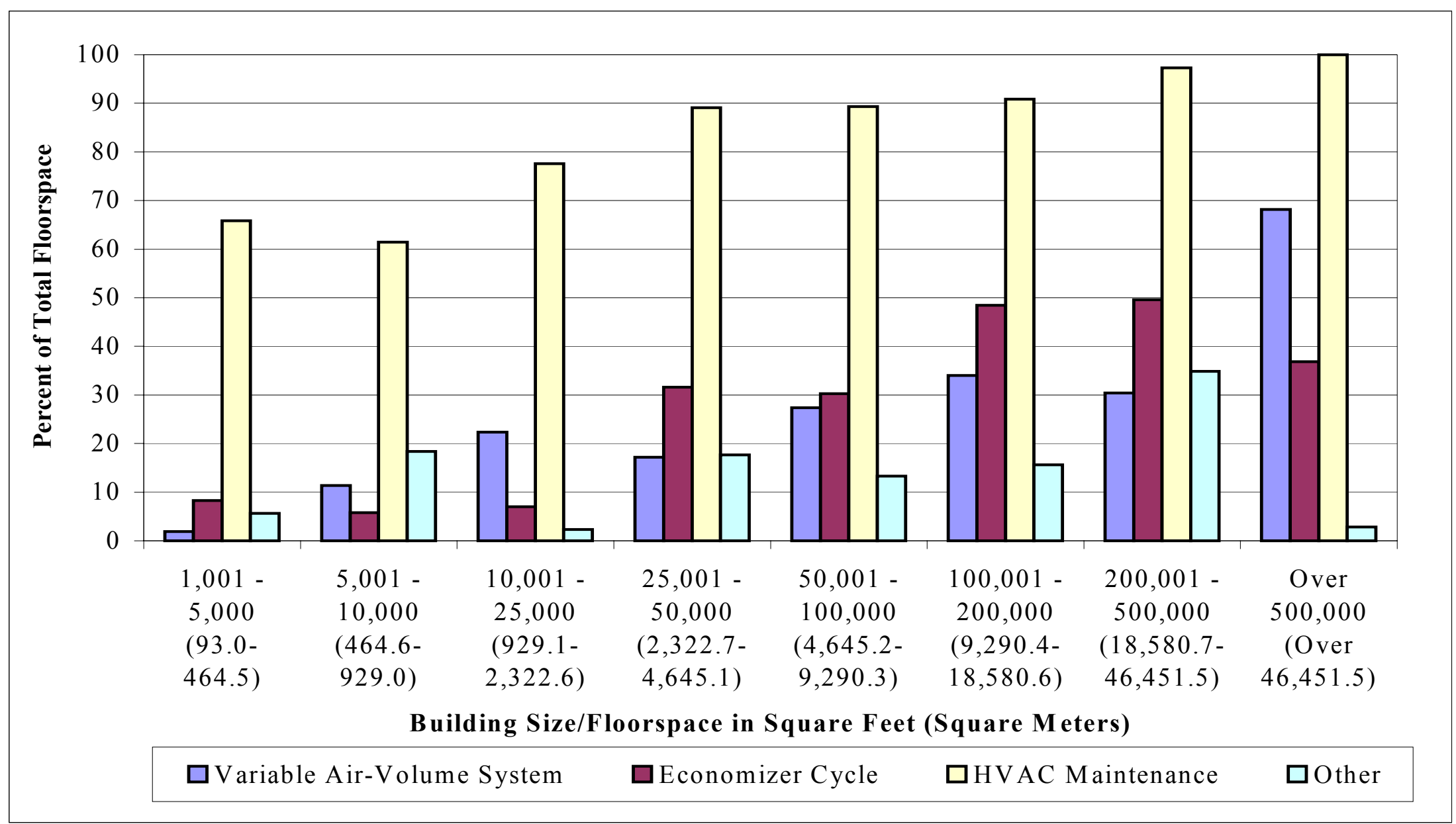


Figure 4-13. Educational Facilities Lighting Conservation Features by Building Size Category

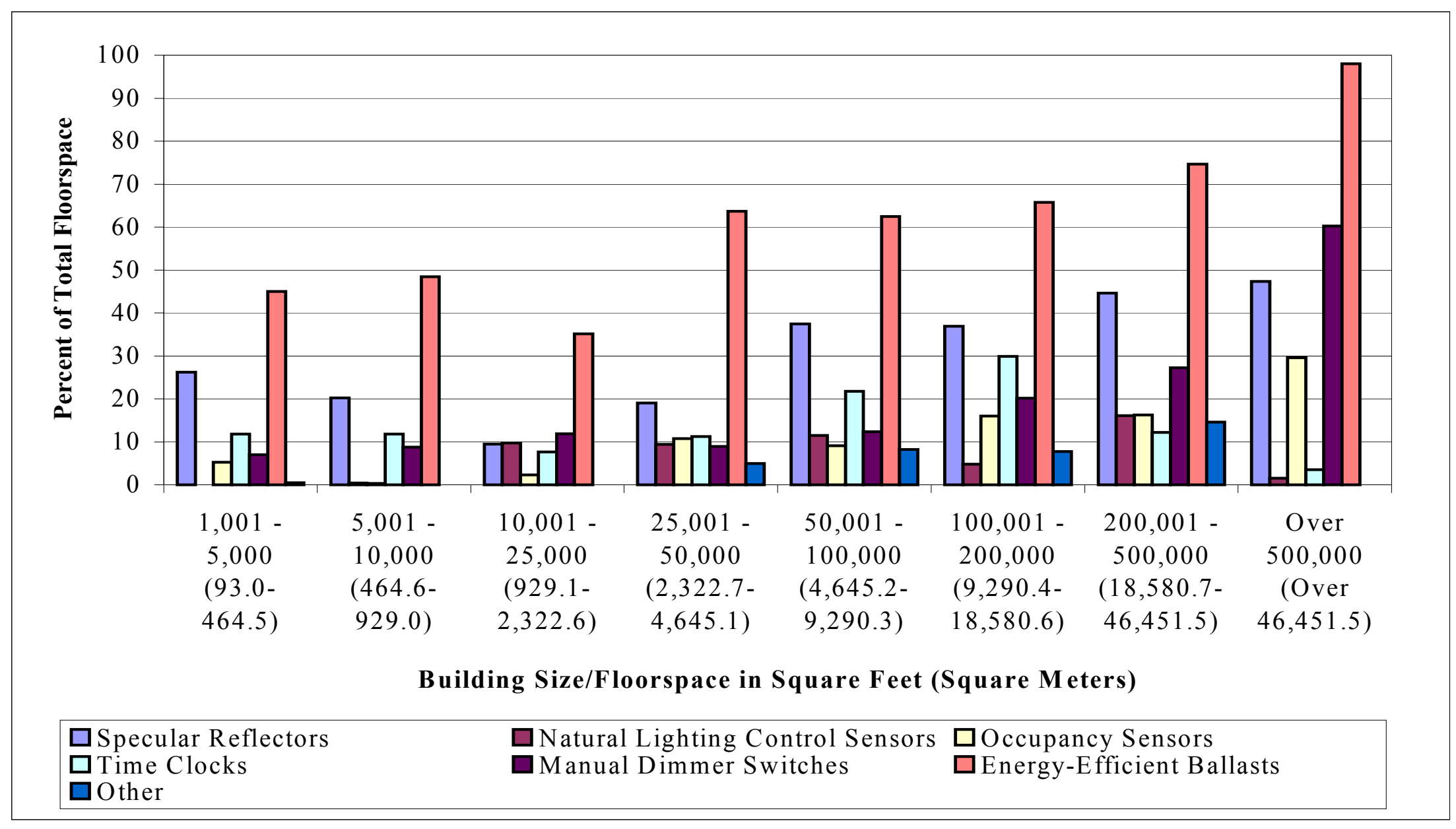


Figure 4-11 summarizes information on building shell conservation features. Figure 4-11 shows that most educational facilities had some type of building shell conservation feature. The feature most often found was roof or ceiling insulation; utilization of roof or ceiling insulation ranged from 70 to $90 \%$ of total floorspace within each size category.

Figure 4-12 summarizes information on HVAC conservation features. Comparison between Figure 4-11 and Figure 4-12 shows that HVAC conservation features were, in general, less common than building shell features. HVAC maintenance, the most widely practiced of the HVAC conservation features, was performed in about $80 \%$ of the floorspace. For the five largest size categories, HVAC maintenance was performed in 90 $\%$ or more of the floorspace.

Reference to Figure 4-13 reveals that a significant percentage of educational facilities floorspace employed some type of lighting conservation feature. The most widely used lighting conservation feature was energy-efficient ballasts. About two-thirds of educational facilities floorspace was covered by energy-efficient ballasts. Comparisons between Figures 4-11, 4-12, and 4-13 show that both HVAC and lighting system conservation were more often found in larger educational facilities.

\subsection{Summary of Baseline Measures for Educational Facilities}

This section summarizes the baseline measures for educational facilities that are presented in Sections 4.2.1, 4.2.2, and 4.2.3 of this document. These measures are presented in Table 4-7.

The table is organized to serve as a quick reference; it includes a brief description of each measure, the year for the data, the value of the measure in dollars per $\mathrm{m}^{2}$ (per $\mathrm{ft}^{2}$ ), and the source of the data. Two sets of summary OM\&E measures are presented first-one for K-12 facilities and one for college and university facilities - followed by a more detailed set of measures. 
Table 4-7. Summary of OM\&E Baseline Measures for Educational Facilities

\begin{tabular}{|c|c|c|c|}
\hline DESCRIPTION & YEAR & BASELINE & SOURCE \\
\hline OM\&E: K-12 Facilities & 1996 & $\$ 35.74 / \mathrm{m}^{2}\left(\$ 3.32 / \mathrm{ft}^{2}\right)$ & AS\&U \\
\hline $\begin{array}{l}\text { OM\&E: College \& University } \\
\text { Facilities }\end{array}$ & 1996 & $\$ 37.78 / \mathrm{m}^{2}\left(\$ 3.51 / \mathrm{ft}^{2}\right)$ & AS\&U \\
\hline $\begin{array}{l}\text { Average Custodial (Cleaning) } \\
\text { Cost }\end{array}$ & $\begin{array}{c}1993- \\
1994\end{array}$ & $\$ 9.81 / \mathrm{m}^{2}\left(\$ 0.91 / \mathrm{ft}^{2}\right)$ & APPA \\
\hline Average Grounds Cost & $\begin{array}{l}1993- \\
1994\end{array}$ & $\$ 2.96 / \mathrm{m}^{2}\left(\$ 0.28 / \mathrm{ft}^{2}\right)$ & APPA \\
\hline $\begin{array}{l}\text { Average Solid Waste Disposal } \\
\text { Cost }\end{array}$ & $\begin{array}{c}1993- \\
1994\end{array}$ & $\$ 0.56 / \mathrm{m}^{2}\left(\$ 0.05 / \mathrm{ft}^{2}\right)$ & APPA \\
\hline $\begin{array}{l}\text { Average Hazardous Waste } \\
\text { Disposal Cost }\end{array}$ & $\begin{array}{c}1993- \\
1994\end{array}$ & $\$ 0.40 / \mathrm{m}^{2}\left(\$ 0.04 / \mathrm{ft}^{2}\right)$ & APPA \\
\hline Average Security Cost & $\begin{array}{l}1993- \\
1994\end{array}$ & $\$ 3.81 / \mathrm{m}^{2}\left(\$ 0.35 / \mathrm{ft}^{2}\right)$ & APPA \\
\hline $\begin{array}{l}\text { Average Building Maintenance } \\
\text { Cost }\end{array}$ & $\begin{array}{c}1993- \\
1994\end{array}$ & $\$ 9.63 / \mathrm{m}^{2}\left(\$ 0.90 / \mathrm{ft}^{2}\right)$ & APPA \\
\hline Average Electricity Cost & $\begin{array}{c}1993- \\
1994\end{array}$ & $\$ 10.61 / \mathrm{m}^{2}\left(\$ 0.99 / \mathrm{ft}^{2}\right)$ & APPA \\
\hline Average Gas Cost & $\begin{array}{c}1993- \\
1994\end{array}$ & $\$ 3.54 / \mathrm{m}^{2}\left(\$ 0.33 / \mathrm{ft}^{2}\right)$ & APPA \\
\hline Average Water and Sewer Cost & $\begin{array}{c}1993- \\
1994\end{array}$ & $\$ 0.43 / \mathrm{m}^{2}\left(\$ 0.04 / \mathrm{ft}^{2}\right)$ & APPA \\
\hline $\begin{array}{l}\text { Sum of Major Fuel Expenditures: } \\
\text { All Educational Facilities }\end{array}$ & 1995 & $\$ 9.90 / \mathrm{m}^{2}\left(\$ 0.92 / \mathrm{ft}^{2}\right)$ & CBECS \\
\hline
\end{tabular}




\section{Summary and Suggestions for Further Research}

\subsection{Summary}

The Construction and Building Subcommittee of the National Science and Technology Council is developing baseline measures of current construction industry practices and measures of progress with respect to each of the seven National Construction Goals. The seven National Construction Goals are concerned with: (1) reductions in the delivery time of constructed facilities; (2) reductions in operations, maintenance, and energy costs; (3) increases in occupant productivity and comfort; (4) reductions in occupant-related illnesses and injuries; (5) reductions in waste and pollution; (6) increases in the durability and flexibility of constructed facilities; and (7) reductions in construction worker illnesses and injuries. This document provides a detailed set of baseline measures for National Construction Goal 2 (reductions in operations, maintenance, and energy costs) for educational facilities. As such, it describes data sources, data classifications, and the metrics used to develop the baseline measures.

Chapter 1 provides background information about the project, its purpose, and scope. Chapter 2 introduces the National Construction Goals and describes how a well-defined set of metrics is used to develop the baseline measures. Chapter 3 provides an overview of the construction industry. The overview provides the context within which the baseline measures for educational facilities are developed. Chapter 4 presents the baseline measures for educational facilities.

Extensive use of charts and tables is made throughout this document to illustrate the process by which the baseline measures were developed. Sufficient data have been collected to establish baseline measures for OM\&E costs for educational facilities. However, the level of detail of the baselines is highly variable, depending on data availability.

\subsection{Suggestions for Further Research}

The work for this document uncovered areas of research that might be of value to government agencies and private bodies who are responsible for the operations and maintenance of educational facilities. These areas are concerned with: (1) additional data collection; and (2) evaluation of progress toward achievement of National Construction Goal 2.

The Commercial Buildings Energy Consumption Survey (CBECS) provides a wealth of information on educational facilities. The CBECS micro-data files proved invaluable in establishing the characteristics of educational facilities. Unfortunately, the CBECS micro-data files do not provide a means for separating K-12 facilities from college and university facilities. Thus, the characteristics presented in this document are for the educational sector as a whole rather than for K-12 facilities or college and university facilities, respectively. 
If such data were collected and made available, it would result in a much better understanding of the characteristics of both types of educational facilities (i.e., K-12 and college and university). It is important to note that the 1995 edition of the CBECS questionnaire contains the type of information needed to distinguish among different types of educational facilities. ${ }^{28}$

Having such detailed information would prove of value beyond measuring energy-related characteristics and expenditure patterns. For example, an expanded CBECS information resource represents an opportunity to measure a particular facility's performance against national characteristics for a similar type of actual facility. This information would also prove of value in establishing prototypical facilities from which non-energy-related estimates for operations and maintenance costs can be derived and used as metrics against which an actual facility's performance could be measured and evaluated.

Finally, in order to be able to measure progress toward National Construction Goal 2, periodic reports need to be produced which re-visit the same data sources used to generate the baselines, and refine or expand the original baselines as necessary to meet the changing needs of the stakeholders in the educational sector.

\footnotetext{
${ }^{28}$ The types of educational facilities covered in the CBECS questionnaire include: preschool, elementary, junior high, senior high, college or university classrooms/laboratories, and vocational school.
} 


\section{References}

American School \& University. 1996. 1996 AS\&U Maintenance \& Operations Cost Study. Overland Park, KS: American School \& University.

American Society for Testing and Materials. 1998. Standard Classification for Building Elements and Related Sitework-UNIFORMAT II. E-1557. West Conshohocken, PA: American Society for Testing and Materials.

The Association of Higher Education Facilities Officers. 1995. 1993-94 Comparative Costs and Staffing Report for Colleges and University Facilities. Alexandria, VA: The Association of Higher Education Facilities Officers.

Building Owners and Managers Association. 1994. Experience Exchange Report, National Cross-Tabulations, 1994. Washington, DC: Building Owners and Managers Association.

The Center to Protect Workers' Rights. 1997. The Construction Chart Book: The US Construction Industry and Its Workers. Report D1-97. Washington, DC: The Center to Protect Workers' Rights.

Chapman, Robert E. 2000. An Approach for Measuring Reductions in Construction Worker Illnesses and Injuries: Baseline Measures of Construction Industry Practices for the National Construction Goals. NISTIR 6473. Gaithersburg, MD: National Institute of Standards and Technology.

Chapman, Robert E., and Roderick Rennison. 1998. An Approach for Measuring Reductions in Delivery Time: Baseline Measures of Construction Industry Practices for the National Construction Goals. NISTIR 6189. Gaithersburg, MD: National Institute of Standards and Technology.

Chapman, Robert E., and Roderick Rennison. 1998. An Approach for Measuring Reductions in Operations, Maintenance, and Energy Costs: Baseline Measures of Construction Industry Practices for the National Construction Goals. NISTIR 6185. Gaithersburg, MD: National Institute of Standards and Technology.

Fuller, Sieglinde K., and Stephen R. Petersen. 1996. Life-Cycle Costing Manual for the Federal Energy Management Program. NIST Handbook 135. Gaithersburg, MD: National Institute of Standards and Technology.

Lufkin, Peter S., and Anthony J.Pepitone. 1996. The Whitestone Building Maintenance and Repair Cost Reference 1996. Seattle, WA: Whitestone Research.

Rogers, R. Mark. 1994. Handbook of Key Economic Indicators. Burr Ridge, IL: Irwin Professional Publishing. 
US Department of Commerce. 2001. Current Construction Reports: Value of Construction Put in Place. C30. Washington, DC: US Bureau of the Census.

US Department of Energy. 1997. Commercial Buildings Characteristics 1995. DOE/EIA-E024695. Washington, DC: Energy Information Administration.

US Department of Energy. 1998. A Look at Commercial Buildings in 1995: Characteristics, Energy Consumption, and Energy Expenditures. DOE/EIA-0625(95). Washington, DC: Energy Information Administration.

Wright, Richard N., Arthur H. Rosenfeld, and Andrew J. Fowell. 1994. Rationale and Preliminary Plan for Federal Research for Construction and Building. NISTIR 5536. Washington, DC: National Science and Technology Council.

Wright, Richard N., Arthur H. Rosenfeld, and Andrew J. Fowell. 1995. Construction and Building: Federal Research and Development in Support of the US Construction Industry. Washington, DC: National Science and Technology Council.

Wright, Richard N. 1995. "Government and Industry Working Together." Construction Business Review (January/February): pp. 44-49. 